\title{
THIS IS THE AMERICAN EARTH: AN EXHIBITION AND BOOK BY ANSEL ADAMS, NANCY NEWHALL, AND THE SIERRA CLUB
}

\author{
by \\ Josephine Minhinnett, \\ BA Honours, Queen's University, \\ Kingston, Ontario, 2012

\begin{abstract}
A thesis presented to Ryerson University and
Photography and Film
\end{abstract} \\ George Eastman House International Museum of
}

\author{
in partial fulfillment of the \\ requirements for the degree of \\ Master of Arts \\ in the Program of
}

Photographic Preservation and Collections Management

Toronto, Ontario, Canada, and Rochester, New York, USA, 2014

(C) Josephine Minhinnett 


\section{AUTHOR'S DECLARATION PAGE}

I hereby declare that I am the sole author of this thesis. This is a true copy of the thesis, including any required final revisions, as accepted by my examiners.

I authorize Ryerson University and George Eastman House International Museum of Photography and Film to lend this thesis to other institutions or individuals for the purpose of scholarly research.

I further authorize Ryerson University and George Eastman House International Museum of Photography and Film to reproduce this thesis by photocopying or by other means, in total or in part, at the request of other institutions or individuals for the purpose of scholarly research.

I understand that my thesis may be made electronically available to the public. 


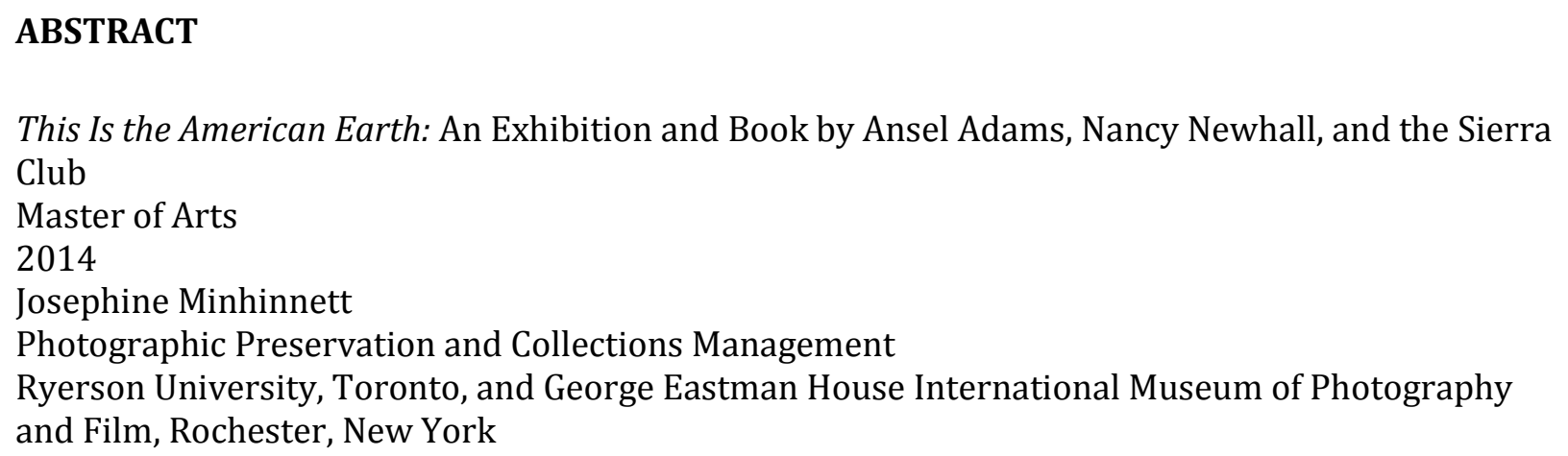

This Is the American Earth: An Exhibition and Book by Ansel Adams, Nancy Newhall, and the Sierra Club Master of Arts

2014

Josephine Minhinnett Photographic Preservation and Collections Management Ryerson University, Toronto, and George Eastman House International Museum of Photography and Film, Rochester, New York

During a remarkable period of growth for the Sierra Club during the Cold War, the club sponsored This Is the American Earth in 1954, a collaborative project between Ansel Adams and Nancy Newhall that resulted in a 1955 exhibition of photographs and a 1960 photobook on the theme of nature conservation. The two productions of photography provide a crucial opportunity to examine how the medium was employed as a campaign tool and an instrument of propaganda over a period of six years. Yet, the project has been almost exclusively defined by its 1960 book. This thesis aims to recuperate the message and import of the 1955 exhibition to determine the function of the entire project, significantly revealing that in addition to being a social and political device, This Is the American Earth marked a critical point in Adams's and Newhall's ongoing battle for photography's recognition as a fine art. 


\section{ACKNOWLEDGEMENTS}

Many people have graciously given their time and assistance to the development of this thesis. Firstly, thank you to David Featherstone for sharing your research and lending me important files on the project. At the Center for Creative Photography, thank you to David Benjamin for your great assistance throughout my research visit, and a special thanks to Leslie Squyres for granting access to my research material and for your ongoing patience in answering my continuous stream of requests. To my first reader, Jessica McDonald, I cannot express how grateful I am for your constant enthusiasm, guidance, and expert editorial hand. Thank you for sharing your personal insights and your personal library with me. To my second reader, Jessica Johnston, I am truly appreciative of the generosity of your advice and your strong words of encouragement. Thank you to the staff in the photography department at George Eastman House: Jamie Allen, Lisa Hostetler, Barbara Galasso, William Green, Ross Knapper, and Joe Struble for your feedback and support, and to my colleagues, Aya Sato and Darren Kinsman for your warm camaraderie throughout the process. To my Program Directors David Harris and Marta Braun, I am deeply grateful for your early encouragement in this topic and for your mentorship throughout my graduate studies. Thank you to David Scheinbaum for granting me permission to use unpublished material by Nancy Newhall, and thank you to the Ansel Adams Publishing Rights Trust for granting me permission to use material by Ansel Adams. Lastly, thank you to the Social Sciences and Humanities Research Council for the Joseph-Armand Bombardier Canada Graduate Scholarship, which enabled me to freely pursue this topic of research. 
CHAPTER ONE: PERSPECTIVES AND MOTIVATIONS

THE SIERRA CLUB, ANSEL ADAMS, DAVID BROWER, AND NANCY NEWHALL ......................................13

1.1 THE SIERRA CLUB AND CONSERVATION …...............................................................................13

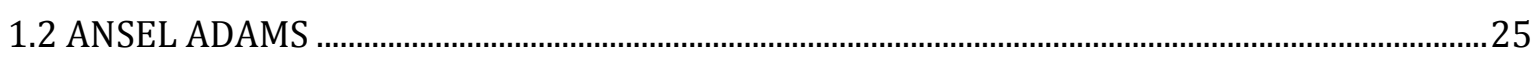

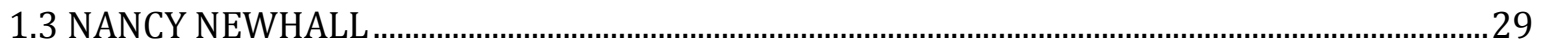

CHAPTER TWO: THE EXHIBITION THIS IS THE AMERICAN EARTH ………............................................... 32

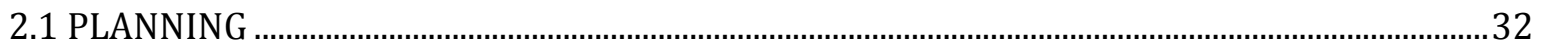

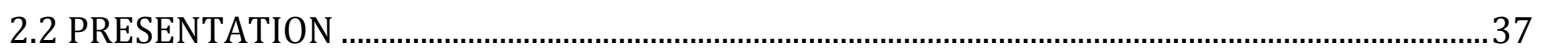

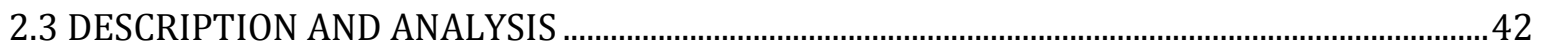

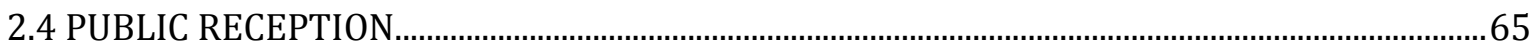

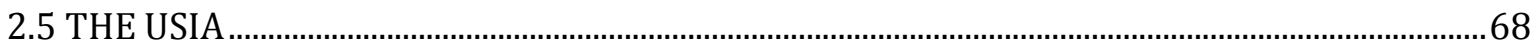

CHAPTER THREE: THE BOOK THIS IS THE AMERICAN EARTH ……......................................................72

3.1 TRANSFORMATION: FROM EXHIBITION TO BOOK.................................................................. 72

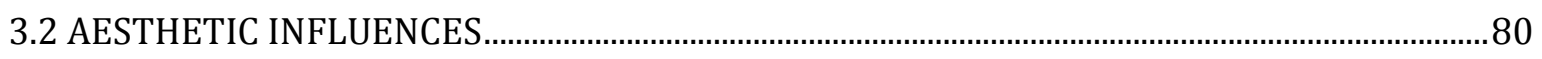

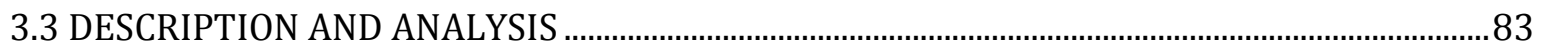

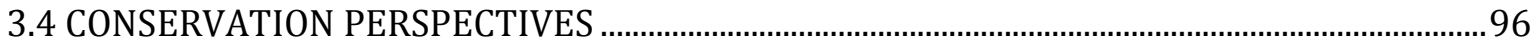

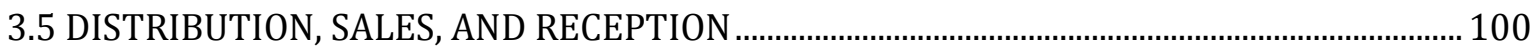

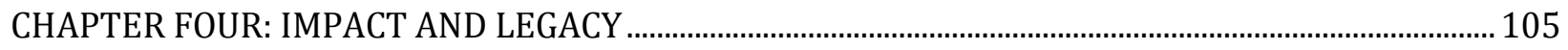

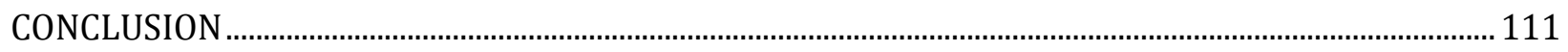

APPENDIX A: This Is the American Earth Exhibition Photograph Sources ............................................ 114

APPENDIX B: This Is the American Earth Exhibition and Book Literary Sources .................................. 115

APPENDIX C: This Is the American Earth Exhibition Itinerary............................................................... 117

APPENDIX D: This Is the American Earth Exhibition Checklist................................................................ 119

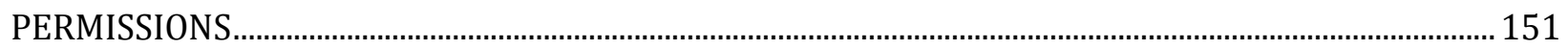

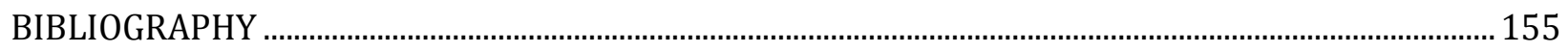




\section{INTRODUCTION}

Beginning in 1954, the American landscape photographer Ansel Adams (1902-1984) and the writer, editor, and photography curator Nancy Newhall (1908-1974) began working together on a nature conservation-themed project called This Is the American Earth sponsored by the California outdoors group, the Sierra Club, in which Adams was a long-standing member. The project consisted of a one-room panel exhibition of 103 photographs and creative prose that opened in 1955, and a high-quality 1960 book on a similar theme containing eighty-five reproductions of primarily landscape photographs combined with poetic text. As a project conceived within the context of the Sierra Club, This Is the American Earth was intended to educate and persuade a broad audience to conserve America's wilderness and natural resources. While This Is the American Earth and its historical contexts have been explored in the literature on photography, the exhibition has frequently been given superficial treatment as a precursory event to the book. Chronologically, this is true, yet this thesis aims for a more comprehensive treatment of the project by giving the exhibition equal consideration as the book, in order to understand how each of them reflected a specific time and set of motivations in the history of photography as well as the history of the conservation movement.

Leading up to This Is the American Earth, Adams and Newhall had already been creatively collaborating on a series of articles and books. They had known each other since the late 1930s through their joint effort to establish a department of photographs at the Museum of Modern Art, and since then they had developed a close friendship and working partnership. In the midst of their long line-up of projects, they embarked on producing This Is the American Earth, which would consume their energies for a period of six years from 1954 to 1960. For the first part of the project

- the exhibition-Newhall, as curator, arranged the photographs and composed the text while Adams made prints and coordinated the logistics of installing the exhibition. For the book, Newhall was again responsible for the arrangement of photographs and text, while Adams oversaw the reproductions, printing, and logistics of book production and distribution. Although they had separate roles, Adams and Newhall worked closely together on all decisions regarding the exhibition and the book to craft a particular message about nature conservation.

The project was a highly collaborative venture involving members of the Sierra Club, as well as experts on conservation whom Newhall consulted during her research. One notable Sierra Club 
member who played a large role in developing the book was David Brower, the first Sierra Club Executive Director. Brower and Adams shared a similar viewpoint on nature conservation and a deep commitment to the traditions and activities of the Sierra Club. In addition to the many actors who participated in the production of This Is the American Earth, several organizations became involved in the project's subsequent dissemination. The Smithsonian Institution circulated the exhibition This Is the American Earth across the United States beginning in 1956 and the United States Information Agency (USIA) sponsored a worldwide tour beginning in 1957 as part of its program to endorse American culture and prevent the spread of Communism.

It is necessary to familiarize the reader with the two main actors in This Is the American Earth, Adams and Newhall, in order to understand how the project has been addressed thus far in the literature on photography. Ansel Adams is well recognized in current scholarship for his advocacy of straight photography and photography as a fine art during a time when few museums included photography in their collections or exhibited photography as more than illustration. His "zone system," which dramatically expanded the possibilities of the camera, has been studied in depth and has given Adams a reputation for being a skilled technician of the camera and master printer. ${ }^{1}$ Adams was also an avid teacher and promoter of higher education as a way to advance photography as a vocation, and he actively influenced a generation of photographers through his workshops, courses, and lectures at universities, fine art schools, conferences, and photography clubs. Like many other photographers, Adams concurrently worked on commercial assignments, many of which employed him for his photographs of the American landscape. Ultimately, Adams had a long-term influence on photography's acceptance as a fine art and the subsequent development of a nascent fine art photography market. Known for his majestic landscape photographs, he was also a serious advocate for environmental conservation, and hoped that through his photographs, he could help to preserve the astounding natural beauty of his country to which he felt a deep sense of responsibility, and which in turn gave him a profound feeling of meaningful existence in the world.

It was through books that Adams could communicate and share his vision with a large audience at a time when photography was vying for a place in the art museum. He published several books and portfolios on America's natural scene, focussing much of his work on the national parks. In his first

${ }^{1}$ Adams primarily gained recognition as a skilled photographer through his "how-to" books on photography, Basic Photo, Vol. 1 The Camera and Lens (New York: Morgan and Lester, 1948); Vol. 2 The Negative (New York: Morgan and Lester, 1948); Vol. 3 The Print (New York: Morgan and Lester, 1950). 
book Taos Pueblo, published in 1930, Adams collaborated with the writer and environmental activist Mary Austin to produce a limited edition book with tipped-in photographic illustrations. ${ }^{2}$ In 1938, Adams produced Sierra Nevada: The John Muir Trail containing high-quality reproductions of landscape photographs, in commemoration of the Sierra Club member Walter "Pete" Starr Jr. Additionally, with his wife Virginia Adams as publisher, Adams produced the hugely successful Illustrated Guide to Yosemite Valley as well as My Camera In Yosemite Valley, and from the thousands of negatives he produced during a Guggenheim Fellowship beginning in 1946, he completed My Camera in the National Parks and Portfolio Two: The National Parks and Monuments in 1950.3 In these and later years, a key partner in Adams's projects was Nancy Newhall with whom he published many books and articles and mounted important exhibitions of his work. Although there have been recent attempts to examine Newhall's major contributions to the field, her work has largely been overshadowed by the photographers and her husband Beaumont whom she collaborated with on books and exhibitions. Yet, throughout her life, Newhall made significant contributions to the critical study of photography through her published essays, articles, books, and reviews, in addition to numerous exhibitions and her role in co-founding the photography journal Aperture. ${ }^{4}$ Thus, it is necessary to outline in greater detail the events in Newhall's life and her relationship to Adams as well as the field of photography.

Nancy Newhall, born Nancy Wynne Parker, was a writer, editor, photography critic, and museum curator who began her career as an artist. After studying painting, creative writing, and theatre at Smith College, Newhall became a member of the Art Students League in New York in the 1930s. She showed great promise as a young painter and secured a solo exhibition of her paintings at the Grace Horne Gallery in Boston. It was through her interest in art that she met her husband Beaumont Newhall in 1933 while he was an art history graduate student at Harvard University. He later became the librarian at the Museum of Modern Art (MoMA). It was soon after their marriage in 1936, while fervently helping Beaumont to organize his MoMA exhibition Photography 1839 -1937, that Nancy decided to devote the rest of her life to photography. ${ }^{5}$ Newhall was considerably involved in her husband's work at MoMA although she was given no official position at the museum,

\footnotetext{
2 Ansel Adams and Mary Austin, Taos Pueblo (San Francisco: Grabhorn Press, 1930).

${ }^{3}$ Adams, Sierra Nevada: The John Muir Trail (Berkeley: Archetype Press, 1938); Illustrated Guide to Yosemite Valley, ed. Virginia Adams (San Francisco: H.S. Crocker Co., 1940); My Camera in Yosemite Valley, ed. Virginia Adams (San Francisco: H.S. Crocker Co., 1940); My Camera in the National Parks (Boston: Houghton Mifflin, 1950); Portfolio Two: The National Parks and Monuments (San Francisco: Grabhorn Press, 1950).

${ }^{4}$ Beaumont Newhall, introduction to From Adams to Stieglitz: Pioneers of Modern Photography, by Nancy Newhall (New York: Aperture Foundation, 1989).

5 Ibid.
} 
and she was indeed involved in the original plans, with Beaumont, Ansel Adams, and the museum trustee Dave McAlpin, to found MoMA's first department of photography in 1940.6 Just a year prior, the Newhalls and Adams had met in New York during the installation of Adams's work in an exhibition at MoMA, and by the summer of 1940, the three were close friends. ${ }^{7}$

With the onset of World War II and the wartime absence of her husband in their newly founded department of photography, Newhall stepped in to fill his position from 1942 to 1945 in the capacity of assistant curator, and was later given the official title of acting curator. ${ }^{8}$ The war years were an exceedingly productive time for Newhall, who took reign of the department's curatorial activities and launched a full program of exhibitions and events. She staged fifteen photography exhibitions, which included the work of photographers Eliot Porter, Helen Levitt, W. Eugene Smith, Weegee, Harry Callahan, Aaron Siskind, and others. ${ }^{9}$ She also produced the first major retrospectives of the photographers Paul Strand and Edward Weston, complete with illustrated catalogues, in addition to founding a photography center at MoMA in 1943 with a program of lectures, workshops, and smaller exhibitions. ${ }^{10}$

It was during this time that Newhall's and Adams's close friendship truly began to develop, with Adams giving lectures in New York and Newhall organizing an exhibition of his work, Manzanar: Photographs by Ansel Adams of Loyal Japanese American Relocation.11 Many productive discussions between them emerged from this time and secured their creative partnership on projects in future years. Upon Beaumont Newhall's return from the Second World War in 1945, Edward Steichen, the Newhalls' ideological antithesis in photography, became director of the department of photography, and the Newhalls, loyal to the ideals of Alfred Stieglitz and outraged by this unexpected change in

${ }^{6}$ This is evident from her detailed written record of the early years of the founding of the department of photography at MoMA in her unpublished manuscript, Enduring Moment, ca. 1971, Nancy Newhall Collection at the Center for Creative Photography, University of Arizona, Tucson [hereafter cited as NN at $\mathrm{CCP}$.

${ }^{7}$ Erin Kathleen O’Toole, “No Democracy in Quality: Ansel Adams, Beaumont and Nancy Newhall, and the Founding of the Department of Photographs at the Museum of Modern Art," (doctoral dissertation, University of Arizona, 2010), 171.

${ }^{8}$ Ibid., 328. Newhall was only officially given the title of acting curator in July 1943.

${ }^{9}$ Beaumont Newhall, introduction to From Adams to Stieglitz: Pioneers of Modern Photography, by Nancy Newhall (New York: Aperture Foundation, 1989).

10 O'Toole, "No Democracy in Quality," 237. Paul Strand: Photographs, 1915-1945, was exhibited from April 25 to June 10, 1945, and was the first retrospective of a photographer at an American museum. The Photographs of Edward Weston was exhibited from February 10 to March 31, 1946. "No Democracy in Quality," 330-31.

11 Ibid., 282. 
their program, left MoMA. The Newhalls soon relocated to Rochester, New York, where Beaumont became a curator, and later the director, at George Eastman House with Nancy assisting on projects as she had done at MoMA.

In the years after the war, Newhall's deep wish to bring to light the work of many significant modernist photographers led her to become an important editor and writer of photographers' books. Already in 1940, she had begun to research and write Stieglitz's biography, although she never finished. She became the editor of The Daybooks of Edward Weston, Volume I, Mexico which was eventually published in 1961 and was followed by the second volume in 1966.12 Newhall was also the co-author of Time In New England, a book she produced with photographer Paul Strand.13 However, it was Adams who was Newhall's most significant collaborator, and as their profuse amount of correspondence reveals, they were also kindred spirits. Newhall and Adams collaborated on numerous books, workshops, commercial assignments, and exhibitions. While the list is by no means exhaustive, it is worth highlighting the fact that Newhall organized a major Adams retrospective in 1963 for the de Young Museum in San Francisco, wrote the first biography of Adams, Ansel Adams: Volume 1, The Eloquent Light, published by the Sierra Club in 1963, and produced many other books with Adams including Death Valley (1954), Mission San Xavier del Bac (1954), and Fiat Lux: The University of California (1967). ${ }^{14}$ In his introduction to a posthumous anthology of Newhall's essays, Beaumont Newhall remarked that among her many collaborative projects with Adams and other photographers, her masterpiece was This Is the American Earth.15

Like many of Newhall's major contributions, This Is the American Earth has been overlooked in the history of photography. It is mostly owing to Adams's popularity as a photographer that reflections on the project have been scattered throughout the history of photography. One likely reason for the scarcity of information on the exhibition This Is the American Earth in particular is its ephemeral nature. A record of the arrangement of photographs and labels on each exhibition panel now only

\footnotetext{
12 Edward Weston, The Daybooks of Edward Weston, Volume 1, Mexico, ed. Nancy Newhall (New York: George Eastman House, 1961); The Daybooks of Edward Weston, Volume 2, California (New York: George Eastman House, 1966).

13 Paul Strand and Nancy Newhall, Time In New England (New York: Oxford University Press, 1950).

${ }^{14}$ Nancy Newhall, Ansel Adams: Volume 1, The Eloquent Light (San Francisco: Sierra Club Books, 1963); Nancy Newhall and Ansel Adams, Death Valley (San Francisco: Five Associates, 1954); Mission San Xavier del Bac (San Francisco: Five Associates, 1954); Fiat Lux: The University of California (New York: McGraw Hill, 1967).

${ }^{15}$ Beaumont Newhall, introduction to From Adams to Stieglitz: Pioneers of Modern Photography, by Nancy Newhall (New York: Aperture Foundation, 1989); Adams and Newhall, This Is the American Earth (San Francisco: Sierra Club Books, 1960).
} 
survives in poor-quality photographic reproductions, which do not clearly convey the heavy textual content of the exhibition. ${ }^{16}$ There are two undated paper copies of the exhibition text known to exist, one of which is housed at the Bancroft Library at the University of California, Berkeley and the other at the Center for Creative Photography at the University of Arizona, Tucson. An evaluation of these documents alongside the photographic reproductions suggests that neither copy of the panel text is the final version, although the Bancroft Library's copy is certainly near complete and bears the handwritten inscription, "Master Text / File Copy." It is partially owing to these variables and others to be discussed in later chapters, that the exhibition has been given superficial treatment in the literature.

This thesis seeks to establish the content and meaning of the exhibition in its comprehensive investigation of This Is the American Earth. With an equal consideration of the exhibition and book, this thesis will answer the following questions: Who influenced the project's content and aesthetic, what was the project's original purpose and message, how were photographs and text used to convey the message, and what was the project's social and political significance? By contextualizing the project's conception, production, and dissemination, this thesis will inform an understanding of This Is the American Earth's full trajectory from panel exhibition, to circulation, to its final realization in book form.

This Is the American Earth has thus far been addressed in only two major scholarly publications. The essay "This Is the American Earth: A Collaboration by Ansel Adams and Nancy Newhall” by David Featherstone, in the Friends of Photography's 1993 publication Ansel Adams New Light: Essays on his Legacy and Legend, focusses on establishing Newhall's role in the project.17 Featherstone uses correspondence between Adams and Newhall, housed at the Center for Creative Photography in Tucson, Arizona, to reconstruct each stage in the exhibition's development and shed light on Newhall's working process. With its primary focus on the exhibition, his essay has been the sole attempt in the literature to describe the exhibition panels. However, a deeper analysis of the content of the panels, as well as their significance in relation to the Sierra Club, were outside the scope of his essay. This thesis will bring those details to light for the first time to establish how the exhibition's development was not only driven by Newhall's creative impulse, but also by a variety of

${ }^{16}$ The photographic slides of the original exhibition panels were generously supplied by independent curator, David Featherstone.

${ }^{17}$ David Featherstone, "This Is the American Earth: A Collaboration by Ansel Adams and Nancy Newhall," in Ansel Adams New Light: Essays on his Legacy and Legend, ed. Michael Read (Carmel: Friends of Photography, 1993), 63-73. 
stakeholders in the American conservation movement. It is relevant to note that Featherstone's research emerged from his re-staging of the exhibition This Is the American Earth for the Sierra Club's $100^{\text {th }}$ anniversary in 1992. In his exhibition proposal, he identified an important area of investigation in the project, in which he found large conceptual differences between the exhibition and the book. ${ }^{18}$ While he did not investigate this in any great depth in his proposal or subsequent essay, his preliminary conclusions form the basis for the line of inquiry in this thesis, which will examine how the exhibition had its own meaning and social import apart from the book.

The second significant study appears in a chapter called "The Intangible Values of the Natural Scene" in Anne Hammond's book Ansel Adams: Divine Performance, published in 2002.19 Hammond allots less of a discussion to Newhall and the exhibition, as she instructively associates the book This Is the American Earth with developments in the American conservation movement. She delivers an informative close reading of the book's images and text, but at times her interpretation of individual images narrowly focusses on Adams's intentions and overlooks the greater context of influences on Newhall's text and image layout. As Hammond's discussion deals almost exclusively with the book, this thesis will supplement her research by probing the exhibition to understand its historical and cultural significance. Nevertheless, this thesis draws heavily from Hammond's chapter to understand how Adams, the Sierra Club, and an additional plethora of social and political actors impacted the message and function of This Is the American Earth. Additionally, between Hammond and Featherstone, significant factual inconsistencies exist; this thesis aims to correct the record and offer new insights on the project's evolution.

Apart from Featherstone and Hammond, This Is the American Earth has been briefly mentioned in two Adams biographies and an oral history interview. In her 1996 Adams biography, former assistant to Adams, Mary Street Alinder, acknowledges This Is the American Earth in a chapter about Adams's growing militancy in the Sierra Club, but without the benefit of a longer discussion, she hastily concludes that This Is the American Earth marked a divergence from Adams's and Newhall's philosophy on photography. Referring to Adams's and Newhall's distaste for Edward Steichen's populist exhibitions at the Museum of Modern Art, Alinder writes that Adams and Newhall had "long ago tried, convicted, and hung Steichen for his use of photography as emotional propaganda,"

18 The differences between the 1955 exhibition and the 1960 book were so vast that Featherstone based his 1992 remount of the exhibition TITAE on the book's image selection, sequence, and text. David Featherstone to Beaumont Newhall, 16 June 1992, Collection of David Featherstone.

${ }^{19}$ Anne Hammond, Ansel Adams: Divine Performance (London; New York: Yale University Press, 2002). 
but that in This Is the American Earth, "it did not seem to occur to them that they themselves might be guilty of the same charge." 20 This thesis will examine the perceived contradiction through a detailed comparison of This Is the American Earth with The Family of Man.

Jonathan Spaulding's 1995 biographical work Ansel Adams and the American Landscape delivers a more methodical historical analysis of This Is the American Earth, relating the project to its environmental context. ${ }^{21}$ He offers a detailed description of the Sierra Club campaigns and other conservation activities that were concurrent with This Is the American Earth, as well as Adams's and Newhall's distinct viewpoints on nature conservation. Significantly, Spaulding traces the stage-bystage development of the project from 1954 to 1960 and illuminates a few key influences, not mentioned in other sources, which impacted the project's evolution from exhibition to book. While Spaulding gives a productive account of the project, his biography does not offer a thorough description of the exhibition and book.

In a 1972 interview organized by the Bancroft Library at The University of California, Berkeley as part of an oral history project on important figures in the history of California, interviewer Ruth Teiser guided Adams to discuss This Is the American Earth in the context of his collaboration with Nancy Newhall.22 Adams provided the basic facts of the project and gave much credit to Newhall for her work on the exhibition and book. He also spoke profusely about the logistics of publishing the book, and in another interview, offered a comparison between the exhibitions This Is the American Earth and The Family of Man. While Adams's first-person account is undoubtedly tinted with personal bias and falsely remembered facts, as an unfiltered narrative it offers invaluable insight into his motivations and views on art, photography, and conservation that influenced the two TITAE productions. From these two biographies and oral history interview, it becomes apparent that there has been little serious inquiry given to situating This Is the American Earth into Adams's greater practice and philosophy as a photographer, despite the fact that he identified it in his autobiography as "possibly the most worthwhile of my projects with Nancy [Newhall]." 23

\footnotetext{
${ }^{20}$ Mary Street Alinder, Ansel Adams: Biography (New York: Henry Holt and Co., 1996), 285.

${ }^{21}$ Jonathan Spaulding, Ansel Adams and the American Landscape: A Biography (Berkeley: University of California Press, 1995).

${ }^{22}$ Ansel Adams, "Conversations with Ansel Adams," oral history, conducted by Ruth Teiser and Catherine Harroun, 1972, 1974, 1975, Sierra Club Oral History Series, Regional Oral History Office, Bancroft Library, University of California Berkeley, 1978, http://bancroft.berkeley.edu/ROHO/collections/subjectarea /natres/sierraclub.html.

${ }^{23}$ Ansel Adams, Ansel Adams: An Autobiography, ed. Mary Street Alinder (Boston: Little, Brown and Co.,1985), 215.
} 
While there are fewer sources of scholarship on Newhall, This Is the American Earth has been cursorily mentioned in an essay on Newhall in a 1997 anthology on female artists and in a 2008 catalogue about Newhall as a curator and photographer. In the 1997 anthology, The Desert Is No Lady: Southwestern Landscapes in Women's Writing and Art, MaLin Wilson's essay "Walking on the Desert in the Sky: Nancy Newhall's Words and Images" substantively investigates how Newhall developed an interest in America's natural landscape, using it as a major subject of her work. ${ }^{24}$ The author duly examines the various projects and events that shaped Newhall's perspective of the wilderness, framing This Is the American Earth (hereafter TITAE) as a culmination of those experiences. Yet the author gives exclusive credit to Newhall and leaves out the role of the Sierra Club, resulting in a profound misunderstanding of the project. In the 2008 catalogue Nancy Newhall: A Literacy of Images, edited by Deborah Klochko and published as part of an exhibition of Newhall's photographs at the San Diego Museum of Photographic Arts, three short essays on Newhall serve as a general introduction to her photographic work reproduced in the remainder of the catalogue, and MaLin Wilson-Powell's essay “An Eloquent Image” provides only a factual overview of TITAE.25

As there has yet to be a comprehensive account of Newhall's life and contributions to the field of photography, it becomes necessary to turn back to Newhall herself to determine her curatorial practice. Although space does not permit a discussion of each article, several of her essays and reviews are crucial to understanding how Newhall approached photography, exhibitions, and book design. There have been a few recent anthologies of her critical body of work. The posthumous book From Adams to Stieglitz: Pioneers of Modern Photography, published by the Aperture Foundation in 1989, presents fifteen of Newhall's most important critical writings on photography with an introduction by her husband, Beaumont Newhall and a foreword by Aperture editor Michael E. Hoffman. Preceding this publication, in 1976, The Friends of Photography dedicated an issue of its journal to Newhall following her death and published the first bibliography of Newhall's works along with a remembrance by Diana Edkins, originally published in Afterimage. ${ }^{26}$

\footnotetext{
${ }^{24}$ MaLin Wilson, "Walking on the Desert in the Sky: Nancy Newhall's Words and Images," in The Desert Is No Lady: Southwestern Landscapes in Women's Writing and Art, eds. Vera Norwood and Janice Monk (Tucson: University of Arizona Press, 1997), 47-61.

25 MaLin Wilson-Powell, “An Eloquent Image," in Nancy Newhall: A Literacy of Images, ed. Deborah Klochko (San Diego: Museum of Photographic Arts, 2008), 20-41, exhibition catalogue.

${ }^{26}$ Nancy Newhall, From Adams to Stieglitz: Pioneers of Modern Photography (New York: Aperture Foundation, 1989); Beaumont Newhall and Peter Hunt Thompson, eds., "Nancy Newhall," Untitled 10 (Carmel: The Friends of Photography, 1976); Diana Edkins, "Nancy Newhall: 1908-1974," Afterimage 2, no. 3 (September 1974): 11.
} 
Adams's and Newhall's creative process was framed by the broader context of the Sierra Club, for which TITAE was created. While there have been a variety of sources that chronicle the ideological battles waged by the club during the 1950s and 60s, only three of these have directly engaged with TITAE. Michael P. Cohen's The History of the Sierra Club, 1892-1970, published by the club, is a thorough account of the club's activities, tactics, leaders, and members over a period of almost eighty years. ${ }^{27}$ Cohen's history portrays the TITAE project as embedded within the rapid growth of the Sierra Club and the slow progression of the American conservation movement consisting of large campaigns as well as individual wins and losses. Additionally, David Brower, the Sierra Club Executive Director during TITAE's creation, summarized the project in his oral history interview conducted by the Bancroft Library, as well as in the second volume of his autobiography Work In Progress. ${ }^{28}$ He emphasized the importance of the book TITAE, identifying it as the beginning of the club's conservation publishing program. Yet, a more edifying source on TITAE is Sarah Orleans Reed's undergraduate honors thesis, “The Publication of Paul Ehrlich's The Population Bomb by the Sierra Club, 1968: Wilderness-Thinking, Neo-Malthusianism, and Anti-Humanism." 29 Reed's paper traces a major ideological shift within the Sierra Club from 1960 to 1968 by analyzing three of its publications, including the book TITAE. Her interpretation of the book, as well as her paper's objectives, are closely aligned with the aims of this thesis.

Not surprisingly, TITAE has generated interest in the field of environmental studies and has been addressed at different lengths in the context of the history of environmental politics. Historian Finis Dunaway's book Natural Visions: The Power of Images in American Environmental Reform investigates photographic and cinematic imagery of the American wilderness from 1920 to the late 1990s. ${ }^{30}$ Dunaway conducts a cultural analysis of a handful of images from the book TITAE, but like the aforementioned photo-historians and authors, he does not engage with the particulars of the exhibition TITAE. American environmental history specialist Thomas Robertson chooses images of India from the book TITAE to launch his interdisciplinary research on American foreign relations

27 Michael P. Cohen, The History of the Sierra Club, 1892-1970 (San Francisco: Sierra Club, 1988).

${ }^{28}$ David Brower, "David R. Brower: Environmental Activist, Publicist, and Photographer," oral history, conducted by Susan Schrepfer, 1974-78, Sierra Club Oral History Series, Regional Oral History Office, Bancroft Library, University of California, Berkeley, 1980; Work in Progress (Salt Lake City: Peregrine Smith Books, 1991).

${ }^{29}$ Sarah Orleans Reed, "The Publication of Paul Ehrlich's The Population Bomb by the Sierra Club, 1968: Wilderness-Thinking, Neo-Malthusianism, and Anti-Humanism," (undergraduate honors thesis, Wesleyan University, 2008), http://wesscholar.wesleyan.edu/cgi/viewcontent.cgi?article=1064\& context=etd_hon_theses; Paul Ehrlich, The Population Bomb (New York: Ballantine Books, 1968).

30 Finis Dunaway, Natural Visions: The Power of Images in American Environmental Reform (Chicago: The University of Chicago Press, 2005). 
during the Cold War. His paper "This Is the American Earth: American Empire, the Cold War, and American Environmentalism," examining government sponsored scientific research on the environment during the Cold War, reveals how post-war Americans developed prevailing ideas about the natural world. ${ }^{31}$ While these academic studies certainly contribute to an understanding of TITAE's cultural and political import, there has been no consideration given to the immediate Cold War context of the exhibition TITAE - such as the role of the USIA — which this thesis will address.

Given the lack of critical engagement with This Is the American Earth in secondary sources, it has been necessary to conduct primary research to build a historically accurate narrative of the evolution and legacy of TITAE. As close friends and collaborators residing on opposite sides of the United States, Adams and Newhall sent frequent and detailed letters to each other regarding their projects, ideas on art and photography, and personal lives. Fortunately, this copious correspondence has been preserved and made accessible for research at the Center for Creative Photography in Tucson, Arizona, as well as at The Getty Research Institute in Los Angeles, California, in the archives of Ansel Adams and Nancy Newhall. Additionally, since Adams and Newhall worked closely with the Sierra Club and David Brower on the project, there is a wealth of correspondence and records on TITAE in the archives of the Sierra Club deposited at the Bancroft Library at The University of California, Berkeley. The preservation of these personal and institutional papers has been an invaluable aid to understanding TITAE's trajectory. Lastly, as a result of TITAE's national and international reach, the Smithsonian Institution Archives and the National Archives and Records Association in Washington, DC, have contributed essential information.

Chapter One of this thesis will establish the principle players in the conception of This Is the American Earth, with a general overview of the Sierra Club up to the beginning of TITAE, the involvement of Adams, Newhall, and Brower with the club and issues in conservation, and lastly, the artistic practices of Adams and Newhall that compelled them to embark on this project. Chapter Two will trace the variety of influences on Adams's and Newhall's process of developing the 1955 exhibition, with the bulk of the chapter devoted to describing the exhibition's visual and textual content. By examining reviews, this chapter will also situate the exhibition This Is the American Earth in the context of the photography scene in Adams's and Newhall's era. In addition, it will

31 Thomas Robertson, "This Is the American Earth: American Empire, the Cold War, and American Environmentalism," Diplomatic History 32, no. 4 (September 2008): 561-84, doi: 10.1111/j.14677709.2008.00713.x. 
briefly attend to the exhibition's political context, especially as it was toured by the USIA. Chapter Three will focus on the transformation from exhibition to book, introducing new details of Newhall's creative process and the role of the Sierra Club during the book's development. The largest section in the chapter will present a close investigation of the book's image content and text in order to determine its precise message and bring to light its similarities and differences from the exhibition. This descriptive analysis will be followed by a discussion of the book's public reception. Chapter Four will address the life of This Is the American Earth after 1960, and its long term impact on the Sierra Club. This Is the American Earth was not only influenced by the aims of individual actors-Adams, Newhall, and Brower-but also reflected larger shifts in the American conservation movement and post-war American culture from 1954 to 1960 . The project emerges as a significant example of what Adams and Newhall envisioned for photography in their pursuit to improve American society and generate wide acceptance for photography as a fine art, and both the exhibition and book provide a crucial opportunity to examine how photography intersected with the rise of modern environmentalism and the Cold War. 
CHAPTER ONE

PERSPECTIVES AND MOTIVATIONS: THE SIERRA CLUB, ANSEL ADAMS, DAVID BROWER, AND NANCY NEWHALL

This Is the American Earth was not the vision of one person, but a product of many agents, each with his or her own goals. This chapter will elucidate the chief aims and ventures of the principal

figures - the Sierra Club, Ansel Adams, Nancy Newhall, and David Brower - to understand the particular set of viewpoints and motivations from which This Is the American Earth grew. Beginning with a brief historical overview of the sponsoring organization, the Sierra Club, the chapter will necessarily establish how Adams, Newhall, and Brower each developed an interest in nature conservation and became involved with the Sierra Club. In conjunction with their individual views on the American wilderness, Adams and Newhall had distinct creative practices and artistic influences that would later impact and inform their elocution of This Is the American Earth. This chapter will illuminate Adams's and Newhall's philosophies on art and photography that were most relevant to their conception and development of This Is the American Earth (TITAE).

\subsection{THE SIERRA CLUB AND CONSERVATION}

The Sierra Club, founded in 1892 by the native-born Scot, naturalist, and wholesaler John Muir (1838-1914), began as a group of outdoor adventurists who shared a deep appreciation for California's Sierra Nevada mountain range and a desire to preserve it for the enjoyment of America's future generations. The first members of the club were primarily intellectuals from the Bay Area and the University of California who had an interest in the Sierra Nevada's opportunities for scientific study in the fields of biology, geology, natural history, and botany. During a camping trip in a northern part of the Sierra Nevada mountain range in Yosemite State Park in the years before the club was established, John Muir convinced the publicist Robert Underwood Johnson that Yosemite required increased protection and management of its lands. Their subsequent campaign successfully secured America's first national park in 1890, named Yosemite National Park, and with this accomplishment they perceived the need for an organization to oversee appropriate recreational use and preservation of the park. On May 28, 1892, a group of prospective members met in San Francisco to sign the Sierra Club into existence with a mission "to explore, enjoy, and render accessible the mountain regions of the Pacific Coast; to publish authentic information 
concerning them," and "to enlist the support and cooperation of the people and government in preserving the forests and other natural features of the Sierra Nevada."1

Muir's philosophy of nature would define the club's activities in the following two decades. Muir, who had developed a deep love for nature through long solitary periods spent exploring, researching, and hiking in the wilderness, believed that "if people in general could be got into the woods, even for once, to hear the trees speak for themselves, all difficulties in the way of forest preservation would vanish."2 Subsequently, the club primarily occupied itself with making the wilderness accessible to the public, and actively promoted recreation and scientific research in the newly founded park. The club mapped and photographed the region to produce park guides, and it launched the Sierra Club Bulletin in 1893, which included climbing guides, scientific reports, and firsthand accounts of excursions. In 1898, the club decided to establish an information center in Yosemite National Park to share its program with a wider public.

As much as the club wanted to increase its membership and spread its mission, it was not yet concerned with any tactical form of public campaigning. The membership primarily consisted of middle-class urbanites who viewed the parks as their quiet pleasure grounds outside of city life. ${ }^{3}$ Members were equally in favor of the economic growth and development of California as they were of the preservation of its wild areas, viewing the parks as necessary and separate from industrial progress. The club would only engage with politics insofar as was necessary to protect their own intellectual and leisurely pursuits. However, by the beginning of the twentieth century, the club's regional location and area of interest in the Sierra Nevada, which lay adjacent to many rapidly expanding cities across the state of California, would position the club amidst the rise of a new government-led movement in conservation led by President Theodore Roosevelt, head of the U.S. Forest Service Gifford Pinchot, and forester Aldo Leopold. A general awareness of the nation's wilderness areas and the natural resources within them had emerged from the recent expansion of the American West and the need for improved resource development to support the growing population. ${ }^{4}$ Conservation was still a nascent term, and as the twentieth century progressed, the club would play a major role in shaping both its meaning and practice.

\footnotetext{
1 Francis Peloubet Farquhar, History of the Sierra Nevada, 2nd ed. (Berkeley: University of California Press, 2007), 217.

2 Michael P. Cohen, The History of the Sierra Club, 1892-1970 (San Francisco: Sierra Club, 1988), 11.

3 Ibid., 9.

4 Ibid., 12.
} 
Ansel Adams was introduced to the Sierra Club during his adolescence. Growing up in a remote area outside San Francisco, Adams had spent most of his childhood outdoors and exploring the natural features around his home. In 1916, at the age of fourteen, he became captivated with the idea of Yosemite Valley, located in the area now designated as Yosemite National Park, through a book he had been given by his Aunt Mary entitled In the Heart of the Sierras by James M. Hutchings. ${ }^{5}$ Eager to see the adventurous setting of Hutchings's travelogue for himself, the young Adams persuaded his family to spend their four-week summer vacation in Yosemite National Park. ${ }^{6}$ It is evident that this first trip to Yosemite made a lasting impression on Adams, as he would return to the park every year for the rest of his life.7 That vacation also marked the beginning of Adams's relationship with photography, as his parents gave him a Kodak No.1 Brownie camera, which he took up enthusiastically to record their trip. ${ }^{8}$

In the following year, Adams returned to the park with his mother and became close acquaintances with the custodian of the Sierra Club headquarters in the LeConte Memorial Lodge, located at the center of Yosemite Valley. That custodian was retired engineer and Sierra Club member Francis Holman, who avidly told Adams stories about the club's excursions in the Sierra Nevada mountain range. ${ }^{9}$ Over the summer, Adams visited the LeConte Memorial Lodge to spend time looking at the club's collection of mountaineering books, in addition to photograph albums of the club's backcountry outings. ${ }^{10}$ Club members had used photography extensively since the founding years; in 1896, a club circular informed its members of a recent acquisition of ninety photographic views made "from negatives taken this summer about the headwaters of the King's River by Mr. J. N. Le Conte."11 Along with the acquisition, the circular welcomed "a beautiful album of views about King's River and Bubb's Creek taken and presented to the Club by Mr. Howard Longley," and the leaflet expressed the club's wish “to place the four or five albums of photographs and the separate framed

${ }^{5}$ Adams, Autobiography, 49-50; James M. Hutchings, In the Heart of the Sierras (Oakland: Pacific Press Publishing House, 1886).

${ }^{6}$ Jonathan Spaulding, Ansel Adams and the American Landscape: A Biography (Berkeley: University of California Press, 1995), 20.

${ }^{7}$ Ibid., 30.

8 Ibid., 21.

${ }^{9}$ Ibid., 31.

10 Ibid.

${ }^{11}$ Circular by Elliott McAllister, "Circular No. 13," 21 December 1896, Sierra Club Board of Directors Meeting Minutes 1892-1907, Bancroft Library, University of California, Berkeley, http://www.oac.cdlib.org /ark:/28722 /bk000775x57/?order=47. 
views upon exhibition in San Francisco and at the two universities."12 Thirty years later, club members were still making photographs of their excursions into the wilderness. As Rebecca Senf remarks in her doctoral dissertation “Ansel Adams's 'Practical Modernism': The Development of a Commercial Photographer, 1916-1936," album-making was an essential part of the club's organized excursions into the wilderness. The club encouraged members to assemble and appropriately number their pictures in albums to enable other members to request copies of photographic prints. ${ }^{13}$ Thus, photography was a social aspect for the club, a way for members to share their interests and recreational experiences.

Adams's interest in photography coincided with his early involvement in the club. He became the caretaker of the club's small collection of books and albums when he successfully applied to be a member of the club in 1919 and earned the position of custodian a year later at the age of eighteen. ${ }^{14}$ At the same time, he yearned for a chance to see the high country. ${ }^{15}$ In his first year as custodian, Adams was invited to join Francis Holman and four other club members on an extended camping trip into the more remote areas of the valley, and over subsequent summers, he continued to meet and expand his network of friends in the club through hiking and camping excursions. ${ }^{16}$ During these trips, Adams, along with other members, used his camera to document exquisite landscapes, as well as the social aspects of the trip. Adams contributed both articles and photographs of these outings to the Sierra Club Bulletin as early as 1921, and beginning in 1928 he served as a member of the Bulletin's editorial board.17

As Adams's matured, he became increasingly involved in the club, both as a photographer and as an experienced outdoorsman. In 1928, at the invitation of the club's president, William Colby, Adams

12 Circular by Elliott McAllister, "Circular No. 13," 21 December 1896, Sierra Club Board of Directors Meeting Minutes 1892-1907, Bancroft Library, University of California, Berkeley, http://www.oac.cdlib.org /ark:/28722 /bk000775x57/?order=47

${ }^{13}$ Rebecca Senf, "Ansel Adams's 'Practical Modernism' : The Development of a Commercial Photographer, 1916-1936," (doctoral dissertation, Boston University, 2008), 123. Adams printed Joseph N. Le Conte's photographs of the Sierra Nevada and assembled them into albums for the club in 1944. "Practical Modernism," 25. For a list of other Sierra Club members who made photograph albums, see Hammond, Divine Performance, 46.

${ }^{14}$ Spaulding, Biography, 33.

15 Ibid., 38.

16 Ibid., 38-9.

${ }^{17}$ For more on Adams's contributions to the Sierra Club Bulletin, see Senf, "Practical Modernism," 156-59. 
participated in the group's trip to the Canadian Rockies as the club's official photographer. ${ }^{18}$ The Sierra Club "High Trip" was the most celebrated annual outing, reserved for the club's more experienced hikers and climbers, and it was undoubtedly a privilege for Adams to be included in the excursion. Adams assembled these pictures into an album for Colby, and he would continue to make albums of the club's outings from 1927 to $1945 .{ }^{19}$ As he grew to be a more experienced hiker, Adams took on a leadership role in the annual High Trip. He not only coordinated the complex logistics of the trip, which now involved more than one hundred campers, but was especially known for enlivening the social atmosphere around the campfire. ${ }^{20}$

The Sierra Club also nurtured a spiritual and emotional relationship to nature in Adams.

Throughout Adams's twenties, members introduced him to nature literature and work by transcendentalist writers. Adams's own writing as a young adult in the club reflected the growth of his deeply personal connection to the wilderness. In his article recounting a club outing composed for the Sierra Club Bulletin, he poetically ruminated, "Space becomes intimate; the world of fixed dimension fades into patterns of exquisite delicacy, and you mingle your being with the eternal quietude of stone."21 Paralleling this spiritual experience of Yosemite, Adams also associated feelings of romance with the park as the place where he met and courted his future wife, Virginia Best, daughter of Harry Best, owner of a souvenir shop and painting studio in Yosemite Valley.22 Throughout the 1920s, Adams and Virginia developed their relationship, and by 1928 they were married.

In 1934, after fifteen years of being involved in all aspects of the club's activities and traditions, Adams was appointed to board member and served in this position for thirty-seven years. ${ }^{23}$ By the 1950s, the decade that would give rise to the TITAE project, Adams had established himself as an important leader in the club. He was an experienced hiker and climber in Yosemite, had been a board member for twenty years, and had actively participated in the activities and traditions that defined the club.

\footnotetext{
18 Senf, "Practical Modernism," 115. By this time, Adams was already gaining commercial success as a photographer. In 1927 he sold several copies of his portfolio the Parmelian Prints with the help of the patron Albert Bender. In 1928 Adams began collaborating on a book project with writer Mary Austin. Spaulding, Biography, 71.

${ }^{19}$ Hammond, Divine Performance, 46.

20 Senf, "Practical Modernism," 123.

21 Ansel Adams, "Retrospect: Nineteen-Thirty-One," Sierra Club Bulletin 17, no. 1 (February 1932): 111, quoted in Hammond, Divine Performance, 10.

22 Spaulding, Biography, 43.

${ }^{23}$ Sierra Club, "History: Ansel Adams," http://vault.sierraclub.org/history/ansel-adams/default.aspx.
} 
The Sierra Club member David Brower (1912-2000) also rose to become a prominent leader in the club during the 1950s. Brower grew up in Berkeley, California, and made his first visit to Yosemite with his family in 1918. Throughout his childhood and teenage years, Brower developed a keen interest in ecology and in 1929 enrolled at the University of California, Berkeley to study entomology. However, he never finished his degree, abandoning it for a more immediate desire to experience the Sierra Nevada mountains. At the time, the Depression years had set in and Brower divided his time between solo climbing trips and finding odd jobs. He first heard about the Sierra Club in 1931 while working at the Berkeley Echo Lake Camp, where he found an entire run of the Sierra Club Bulletin which he began to avidly read as a resource on mountaineering.

It was two years later, during Brower's first extended climbing trip in the summer of 1933, that he became directly acquainted with the club. ${ }^{24}$ During this trip with a few climbing friends, Brower was introduced to Sierra Club member Hervey Voge, who encouraged him to attend the Sierra Club Rock Climbing Section, and by September of that year, he had applied for club membership. ${ }^{25}$ As a new member of the club, Brower joined the editorial board of the Sierra Club Bulletin and began contributing articles, book reviews, and photographs. He soon became acquainted with the printer of the newsletter and during his free time he edited articles and reviewed proofs. He secured a job as the publicity manager at the Yosemite Park and Curry Company (YPCC) in 1935 and 1937, and it was there that he met Adams who had been hired by the YPCC to take publicity photographs. ${ }^{26}$ After their initial meeting, Adams and Brower became closer friends over hiking and camping trips in the high country. In addition to his interest in the Bulletin, Brower was a member of several other of the club's committees and was simultaneously focussed on becoming an accomplished climber; he indeed made many first mountain ascents in Yosemite National Park at a time when climbing equipment was primitive. ${ }^{27}$

After Brower returned from the Second World War in 1946, he became editor of the Bulletin and transformed it from a bi-monthly to a monthly newsletter. It was through publishing photographs and articles in the Bulletin that Brower saw the opportunity to promote the national parks and save

${ }^{24}$ David Brower, "David R. Brower: Environmental Activist, Publicist, and Photographer," oral history, conducted by Susan Schrepfer, 1974-78, Sierra Club Oral History Series, Regional Oral History Office, Bancroft Library, University of California, Berkeley, 1980, 9-10.

25 Ibid., 11.

${ }^{26}$ David Brower, Work in Progress (Salt Lake City: Peregrine Smith Books, 1991), 11.

${ }^{27}$ Cohen, History of the Sierra Club, 71. 
many wilderness areas from being exploited by resource developers. ${ }^{28}$ Brower was an excellent publicist and he modified the design and printing of the Bulletin to make use of the club's full collection of photographs.

In the oral history interview conducted in the early 1970s, Adams most strongly recalled Brower's tremendous energy and dedication to the club. While Brower was working on editing a mountaineering book at the University of California Press, it was Adams who fervently advocated for hiring Brower to work for the club full time, even though there had since been only one paid position in the club. Having convinced the club's president, Richard Leonard, to present his proposal to the Executive Committee, Brower was appointed as the first Executive Director in 1952..$^{29}$ In this position, Brower became a driving force in campaigns against development in the parks, and simultaneously raised awareness for wilderness preservation. He was a savvy publicist who produced two films about the national parks, numerous trail guides, a five-volume reprint of the Sierra Club Bulletin, and a book on Dinosaur National Monument published in 1954.30 Encouraged by the success of Adams's and Newhall's 1960 book This Is the American Earth, the first book in the Sierra Club Exhibit Format Series, Brower began to focus more of his attention on publishing books. From 1960 to 1968 he directed the production of the remainder of the Exhibit Format Series, including nineteen photographically-illustrated books on the importance of wilderness and nature conservation. ${ }^{31}$

The 1950s marked the beginning of change and growth for the Sierra Club. In 1950, the club expanded its reach outside of California to the East Coast by establishing an Atlantic Chapter comprised of eighteen eastern states and the District of Columbia. ${ }^{32}$ At the same time, the decade saw the rise of a new generation of members who called for greater protection of the wilderness, which was divorced from anthropocentric concerns, and they were unwilling to compromise with the National Park Service on proposals for development within the parks. The principle leaders in this movement were Ansel Adams, David Brower, Richard Leonard, and Harold Bradley, and they

28 Brower, Work in Progress, 4.

${ }^{29}$ Adams, Conversations, 670.

30 Catalog of Sierra Club Books, Winter 1962-63, Sierra Club Members Papers, BANC MSS 71/295c, carton 3, folder 30, Bancroft Library, University of California, Berkeley; Wallace Stegner, This Is Dinosaur: Echo Park Country and Its Magic Rivers, (New York: Knopf, 1955).

31 Adams, Conversations, 670; Cohen, History of the Sierra Club, 70.

32 Sierra Club, “History: Sierra Club Timeline," http://www.sierraclub.org/history/timeline.aspx. 
represented a revival of the spiritual and aesthetic ideals of the club's founder John Muir. ${ }^{33}$ The next section will provide an overview of Muir's philosophy on the American wilderness and the club's strategies for protecting the National Parks up until the emergence of TITAE in the 1950s.

As Michael P. Cohen articulates in his History of the Sierra Club, the club was "from the beginning interested in mountaineering, hiking, and camping activities which were part and parcel with nature study or the aesthetic uses of mountains and forests." ${ }^{34}$ Since Congress would only consider preserving areas that were unsuitable for economic development, it became necessary for the club to prove that the parks had value that could not be expressed by a dollar amount. ${ }^{35}$ Muir's solution was to convince both the government and the public that the parks contained an irreplaceable aesthetic and spiritual value, which he believed would be wholly apparent if people could experience the parks. To this end, Muir and founding member William Colby created an "outings program" that would bring visitors into the parks to see and feel the beauty of undisturbed wilderness, and the Sierra Club focussed its energy on promoting recreational opportunities and tourism in the parks. ${ }^{36}$

However, for Muir tourism was simply a strategy to hinder the development of resource industries in the parks and deter the activities of the "progressive conservationists" whose main leader was Gifford Pinchot of the U.S. Forest Service. Overseeing the management of national forest reserves, Pinchot defined conservation as the most efficient use of available resources to meet the human needs of the present. ${ }^{37}$ It was an anthropocentric standpoint that viewed the forests for their longterm benefits to humans and their economic potential. For example, Pinchot advocated for sheep grazing in the forests in support of farming, and in 1906, he accepted a proposal from the city of San Francisco to build a dam near Hetch-Hetchy Valley. The Sierra Club began to question the ability for the U.S. Forest to protect the park, but at this point, it did not have a definitive position on the issue of balancing conservation and development, as many of the members also wanted to see the growth of California's cities.

${ }^{33}$ Cohen, History of the Sierra Club, 67. Although Cohen's list includes Bestor Robinson, I have excluded him here because his views were often contrary to those of Adams and Brower.

${ }^{34}$ Cohen, History of the Sierra Club, 63.

35 Ibid., 7.

${ }^{36} \mathrm{Ibid}$.

37 Ibid., 22. 
However, by the time of the Hetch-Hetchy dam proposal, Muir had distilled his perspective of conservation, viewing nature's value as completely divorced from anthropocentric concerns. He felt that the wilderness was significant for its complex ecology, and his writing reveals an intensely spiritual connection to nature that has often been characterized as religious. ${ }^{38}$ In the early days of the conservation movement, Muir was quite alone and unique in this perspective. Only he and Colby fought against the construction of the Hetch-Hetchy dam at the risk of appearing radical to the club, since the majority of members aligned with the progressive conservationists. Although Muir and Colby lost the fight over Hetch-Hetchy Valley, their political battle would be repeated forty years later, in a strikingly similar Sierra Club protest over the Echo Park Dam in Dinosaur National Monument in the 1950s, concurrent with the production of TITAE.

For the first half of the twentieth century, the Sierra Club had not adopted Muir's philosophy on conservation. The club had allowed development in the parks that was related to tourism, such as the construction of campgrounds, roads, and resorts. The club maintained a friendly relationship with the National Park Service (NPS), which oversaw the management of the parklands under the direction of the Department of the Interior. The NPS's main goal was to promote tourism and build the infrastructure needed to expand tourism in the parks. In 1918, Horace Albright, working as an assistant to the Director of the NPS, Stephen Mather, published the NPS's mission statement in the Sierra Club Bulletin:

First, that the national parks must be maintained in absolutely unimpaired form for the use of future generations as well as those of our time; second, that they are set apart for the use, observation, health, and pleasure of the people, and third that the national interest must dictate all decisions affecting public or private interest in the parks. ${ }^{39}$

The statement reveals that the NPS was mostly concerned with the parks for human benefit and use. The third tenet of the mission enabled the agency to prioritize human needs over the wellbeing of the natural environment. Essentially, this was the prevailing definition of conservation up until the mid-twentieth century. The wilderness was viewed as a trove of natural resources that should be preserved for human enjoyment until there was a greater social or economic need to be fulfilled. Conservation would ensure the use of natural resources in a controlled and non-wasteful manner towards advancing the American nation.

\footnotetext{
${ }^{38}$ Edwin Way Teale, The Wilderness World of John Muir (Boston: Houghton-Mifflin, 1954), xiii.

${ }^{39}$ Cohen, History of the Sierra Club, 45.
} 
The Sierra Club campaigns often consisted of lobbying around NPS initiatives that aligned with their own. For example, the club's strategy to expand the national parks consisted of contributing funds to the NPS's purchase of privately-owned lands, and they could raise funds by organizing large field trips through the parks to convince the public of the beauty of the wilderness. In other instances, when the club disagreed with the NPS on parks management and development proposals, they would negotiate with the NPS to balance the NPS's goals with the least amount of damage to parkland. In these situations, the club ended up compromising on wilderness preservation.

The 1950s heralded a shift in the strategies of the club with a strong group of leaders that more adamantly opposed any kind of development in the parks, to include tourism infrastructure. During this decade, the NPS put forward a proposal to construct two dams in Echo Park at Dinosaur National Monument. The proposal had been pitched as a solution to California's growing demands for water in the post-war housing boom, and was related to several dam proposals introduced by the rapidly expanding city of Los Angeles. The question of dams stemmed from a larger debate over the definition of conservation, which varied amongst club members, governmental organizations, and nature conservation interest groups.

Yet, cautious not to repeat the failure of Hetch-Hetchy, the club would definitively choose one side, and at a major turning point in the legacy of the club, they opposed the dam proposal. The fight was led by Brower, Adams, and other club members who perceived the spiritual and ecological value of undisturbed wilderness. In this new movement, they compelled the public to think about the wilderness as a sacred place that should not bend to anthropocentric and economic ambitions. Ultimately, the Sierra Club's decision to protest the government's plan would sharply redefine the club's mission and identity during the 1950s, and as will be more fully explained in Chapter Two, these conflicts played a direct role in shaping the aims of This Is the American Earth.

From outside the Sierra Club, Nancy Newhall was introduced to the concept of nature conservation through Adams and his wife Virginia. It was at the end of June 1944 that Adams persuaded Newhall to take a much needed vacation from her work as acting curator at MoMA, and spend time in the West with him and Virginia. Newhall was resistant to leave at first, but then decided she could 
coordinate the trip with a visit to Edward Weston to begin work on his upcoming retrospective, in addition to visiting her friends, photographers Imogen Cunningham and Dorothea Lange. ${ }^{40}$

This trip was a turning point for Newhall. Eight years later, she would fondly remember her time with Ansel and Virginia and remark how critical it was to her personal growth. In 1952 she recalled this period in her diary, writing,

The Journey to the West in the spring of 1944 ... the discovery of one's native earth in all its beauty and space and the discovery that somehow there had grown up around me people who liked, respected, or even loved me-to whom I had something very valuable in myself to give-to whom I could speak without fear ... Ansel, probably unaware of it, helped more even than these, hauling me out of my fears and difficulties exactly as he hauled me up precipices, guily, generously insisting on how wonderful B \& N were-until we came to believe it ourselves. ${ }^{41}$

Significantly, the trip also awakened Newhall to the rewards and solace of the natural world. It showed Newhall an entirely different side of America as she climbed up rough cliffs to discover concealed areas of primeval wilderness. ${ }^{42}$ This experience would have deeply contrasted from Newhall's previous view of the American wilderness that she had gained from her Puritan upbringing. As MaLin Wilson-Powell explained in her essay “An Eloquent Image,” in Newhall's 1939 unrealized television script entitled America Makes the Americans, she characterized the American wilderness from the perspective of the European settlers, as a savage place and as a "challenge, a provocateur for human invention." 43 Now, Newhall saw the wilderness as a place that could emotionally and physically nurture humans.

This trip was also Newhall's first introduction to the subject of nature conservation. On this trip, Adams and Virginia introduced Newhall to the work of Mary Austin, a writer and activist who fought against the irrigation of Owens Valley in California, a stunning area that Virginia pointed out to Newhall on their drive to Yosemite National Park. ${ }^{44}$ As Newhall's articles throughout the 1950s reveal, she embraced Mary Austin's interest in the history of the land and the relationship between the land and its early inhabitants.

${ }^{40}$ Alinder, Biography, 178.

41 Nancy Newhall, 20 October 1952, Beaumont and Nancy Newhall Papers 1843-1993 (bulk 19291993), box 243, folder 2, The Getty Research Institute, Research Library, Accession No. 920060 [hereafter cited as Nancy Newhall Papers, GRI].

42 Nancy Newhall, Enduring Moment, unpublished manuscript, 263, cited in Alinder, Biography, 180.

43 Wilson-Powell, “An Eloquent Image,” in Klochko, A Literacy of Images, 25.

44 Wilson, "Walking on the Desert in the Sky," in Norwood and Monk, The Desert Is No Lady, 53. 
As Hammond has written, another influential voice for Newhall in the subject of nature conservation was Sierra Club member Cedric Wright (1889-1959). In 1949, Adams asked Newhall to edit Wright's manuscript for a manifesto on "social reform and nature worship" entitled Words of the Earth, a title borrowed from lines of Walt Whitman's poem Leaves of Grass. ${ }^{45}$ Newhall went as far as making a book dummy with excerpts from the manuscript and Wright's photographs. Even though Wright did not approve of her creative interpretation, Newhall had absorbed many of his ideas and would repeat certain tenets of his theories in later projects including This Is the American Earth.

Shortly thereafter, in 1951, Adams invited Newhall to collaborate with him on a series of six articles commissioned by Arizona Highways magazine about the unique natural regions of the American Southwest. In these articles, Newhall focussed on geography and the history of early inhabitants and explorers in the region. The pair embarked on trips around Arizona and New Mexico where Adams took photographs and Newhall researched, wrote, and arranged the layout of the articles, submitting a complete arrangement of image, text, and size specifications. It was this assignment that gave Newhall the chance to exercise her talents as editor, writer, and designer, and Arizona Highways reproduced her vision in full. Newhall was ecstatic over the success of the collaboration as she wrote to the magazine's editor Raymond Carlson, "You are the first to make use of the Adams-Newhall team in this field! We have worked together, the three of us, in many other fields for a surprising number of years, but $\mathrm{A}[\mathrm{nsel}]$ and I never popped forth as photographer and researcher-writer before!"46 It was the beginning of a vibrant partnership for the creative duo. In 1954, while Adams and Newhall continued working together on projects, turning two of the Arizona Highways articles into books as well as completing a book on Yosemite Valley and another on Northern California, their attention was called to a more urgent project at the Sierra Club that would end up being one of the most significant collaborations in both of their careers.

In January 1954, after fifty years of using the LeConte Memorial Lodge as its headquarters in Yosemite Valley National Park, the Sierra Club was in danger of losing its building. The National Park Service had sent the club a proposal to terminate its 10-year renewable lease and re-purpose

45 Hammond, Divine Performance, 19; 151; Cedric Wright, Words of the Earth, Exhibit Format Series 2, ed. Nancy Newhall (San Francisco: Sierra Club Books, 1960).

${ }^{46}$ NN to Raymond Carlson, 5 July 1952, Nancy Newhall Papers, box 248, folder 2, GRI. 
the lodge as a children's museum. ${ }^{47}$ Although LeConte Lodge was solely maintained and funded by the Sierra Club, the establishment of the National Park Service in 1916 to oversee federal parkland ultimately placed the lodge under NPS control. At the time, the lodge was already serving an informal type of educational function in the park, equipped with a custodian, printed resources for park visitors, and a few samples of botanical specimens. Yet the building was in dire need of renovation, and the NPS saw an opportunity for a more profitable use of the space to promote tourism in the park. Never one to miss an opportunity, Adams proposed that the club refurbish the lodge and use the space for a conservation-themed photography exhibition. Naturally, Adams recommended that his talented friend and recent collaborator, Nancy Newhall, lend her expertise as a curator in conceptualizing and writing text for the show. Enthusiastic to take on another collaborative project, especially one which would enable her to travel to the West and away from Rochester - a place that she found to be exceedingly dull after her busy time at MoMA—Newhall immediately agreed. Over a year's time, she and Adams developed the exhibition for LeConte Lodge as a didactic presentation of the national parks and nature conservation. As an essential part of understanding the project, the next section will establish Adams's and Newhall's individual views on art and photography, which formed the foundation to their approach in This Is the American Earth.

\subsection{ANSEL ADAMS}

By the 1940s, Adams's landscape photographs were landing him considerable commercial success as well as recognition in the photography world. While he did photograph people occasionally, he was known for making straight photographs of pristine landscapes that excluded humans and any possibility of a human presence. It was an intentional choice in subject matter, since by the midtwentieth century, increased tourism and resource development in the parks made it difficult for Adams to take landscape photographs that did not bear the trace of human development. Adams aimed to convey the beauty of a timeless and primeval wilderness, which was deeply connected to his own experiences of nature. Thus, he purposefully photographed highly remote areas of the national parks, capturing landscapes that few park visitors would ever experience. ${ }^{48}$

\footnotetext{
${ }^{47}$ John C. Preston to Richard M. Leonard, 10 February 1954, carton 2, folder 40, Sierra Club Members Papers, Bancroft Library.

${ }^{48}$ Renée Haip, “Forging the Wilderness Idea." In Untitled 55, Ansel Adams New Light: Essays on his Legacy and Legend, ed. Michael Read (Carmel: Friends of Photography, 1993), 75-82.
} 
Even though his landscape photographs lacked human subjects, Adams strongly believed that photographing this particular untouched and unchanging American landscape was a humanist endeavour. It was a perspective that he had gained early on in life through reading the works of theosophists and transcendentalists such as Edward Carpenter, Ralph Waldo Emerson, and Sir Francis Younghusband. ${ }^{49}$ Mirroring his deeply emotional experience with music, Adams's viewed the American landscape as a source of human spirituality and creative inspiration, and he used photography to capture this personal connection to the wilderness. The photographer Henri Cartier-Bresson could not fathom why Adams rarely photographed human subjects, but to Adams, a photograph of unspoiled wilderness was an expression of the human condition, as it conveyed the place where humans could experience the highest degree of creative inspiration and spiritual enlightenment. ${ }^{50}$ It aligned with Stieglitz's belief that photography should be an "affirmation of life." 51 In This Is the American Earth, Adams would present positive examples of the American landscape to educate and emotionally persuade the audience to conserve America's natural resources.

Adams's positive construction of the American wilderness was deeply entwined with his feelings of nationalism and patriotism for America. Summarizing Adams's reaction to an unstable American society on the verge of WWII, Newhall wrote:

The apathy and the cynicism bothered Adams ... If New York and Pittsburgh symbolized America to Easterners, he could understand the lack of will to fight. How to make the people in the Vortex [the East] realize that a tremendous land, continent wide, stretched behind them to the West? That it contained places, mountains, waterfalls, deserts, lakes and coasts as beautiful as any in the world ... Of course there were still injustices, corruptions, and discriminations - but America still had the power to fight them, and the freedoms long since fought for still stood in the laws of the land. ${ }^{2}$

Both Adams and Newhall believed that images of America's exquisite natural wonders would fulfill a moral purpose by instilling a sense of vitality and unity in Americans during a troubled time. With the threat of nuclear annihilation in the post-war years, they again expressed the need for society's spiritual redemption and viewed Adams's photography as a way to elevate morale. This Is the

${ }^{49}$ Hammond covers Adams's literary and artistic influences, as well as his spiritual development in great depth in Chapter One and Chapter Two of her book Ansel Adams: Divine Performance, 1-57.

${ }^{50}$ Henri Cartier-Bresson famously asked, "Why do all the great West Coast photographers photograph stones?" implying that the subject of a photograph should be people. Nancy Newhall, "Photography Is My Passion," in From Adams to Stieglitz, Pioneers of Modern Photography (New York: Aperture Foundation, 1989), 148.

${ }^{51}$ Nancy Newhall, Enduring Moment, unpublished manuscript, quoted in Spaulding, Biography, 178.

52 Nancy Newhall, Enduring Moment, 180, quoted in O'Toole, "No Democracy in Quality,"191. 
American Earth would inevitably be an exhibition of uplifting photography echoing the same nationalistic tone that Adams and Newhall had felt was needed before the war.

Adams's aim to show the beautiful and positive side of America in his photographs was also a direct attempt to separate his work from the negativity and emotional sensationalism of social documentary photography. During the Great Depression, Roy Stryker from the Farm Security Administration (FSA) hired photographers to construct an image of a poor and desperate rural America. Adams vowed to only practice "creative photography" or "expressive photography" in which the subject of the photograph was the subjective emotions of the photographer and the technical proficiency of the camera rather than a representation of a political issue or event. Thus, even with an assignment to photograph serious social atrocities in America, such as the detainment of Japanese-Americans at the Manzanar Japanese internment camp in California during WWII, Adams chose to portray the detainees as though they were living a happy and fulfilling life in the camp.

As a parallel to This Is the American Earth, it is useful to consider an earlier exhibition organized by Adams and the Newhalls, in which nationalist sentiments strongly pervaded. In a letter to Nancy Newhall in 1941, Adams proposed a photography contest and exhibition called Image of Freedom that was meant to inspire national unity and rekindle America's appreciation for democracy during America's anticipation of war..$^{53}$ The exhibition contrasted from the visual clichés of the social documentary method of photography, which sought to depict and dramatize the grueling side of life in order to evoke sympathy for the subject and sway public opinion. Early practitioners of this method included Jacob Riis and Lewis Hine, and later, the Farm Security Administration photographers championed the approach. For the exhibition, Adams and Newhall re-evaluated the meaning of "documentary" photography and posed a new hypothesis. In her curatorial proposal, borrowed for the exhibition's press release, Newhall stated:

We have seen searching photographic studies of the waste of life and land due to abuses that we allowed to accumulate, and we have seen the beginnings of reclamation. Now let us see, with a vision equally exact, the power that can remedy these faults ... What are our resources and our potential strength?"54

${ }^{53}$ Spaulding, Biography, 180.

${ }^{54}$ Museum of Modern Art, "Image of Freedom Photography Competition Opens," press release, 20 June 1941, http://www.moma.org/momaorg/shared/pdfs/docs/press_archives/713/releases/ MOMA_1941_0050_1941-06-20_41620-49.pdf?2010. 
Underlying Newhall's statement lay the conviction that American photographers could find and capture moments of inspiration in a time of instability and conflict. Instead of stirring Americans to action with images of their fear and uncertainty before war, Newhall asked photographers to capture examples of America's beauty and accomplishments as a nation. The exhibition This Is the American Earth would use a similar strategy to persuade the public that nature conservation was an urgent issue for America. Rather than showing images of the vast environmental devastation of America's wilderness, Adams and Newhall chose to present positive and beautiful images of the American landscape to inspire and persuade their audience.

It is worth noting that there were a few instances in which Adams directly used his creative work to advance a social cause. An early example was his book Sierra Nevada: The John Muir Trail (1936), which was created for the Sierra Club member and benefactor Walter A. Starr in memory of his son Pete Starr who died on a climbing trip in the high Sierras. The book was a luxurious large-format tome with photographs tipped in and centered on the page. In the book's foreword, Adams clearly outlined his artistic ambitions as he wrote that "the emotional interpretation of the Sierra Nevadathe revelation of the beauty of wide horizons and the tender perfection of detail-is the prime function of the present work." 55 At the same time, many of the photographs were made in the Kings Canyon region where the Sierra Club was aggressively lobbying for a national park. The Sierra Club sent Adams to a conference in Washington, D.C. where he showed his photographs to members of the NPS to advocate for the Kings Canyon area. Then in 1938, Adams sent the completed book to Harold Ickes, the Secretary of the Interior. Ickes, in turn, passed the book into the hands of President Theodore Roosevelt, who helped to advance the bill for the formation of Kings Canyon National Park in 1940.56

Adams's political use of Sierra Nevada: The John Muir Trail demonstrates that he was committed to photography as an art form, but at the same time, recognized the opportunity to further market his work and use it for a greater social cause. In a letter to Paul Strand, Adams expressed his view on the purpose of exhibitions:

I must admit that I do not fully understand your attitude (and Stieglitz's attitude) about exhibitions in general. I think there are always a few people in any part of the land that would react completely to truly fine things-that would make those things functional in a

55 Ansel Adams, foreword to Sierra Nevada: The John Muir Trail (Berkeley: Archetype Press, 1938). 0'Toole writes that Adams considered these prints to be more topographical than artistic, and thus did not see them as suitable for display in an art museum. "No Democracy in Quality,"139.

56 O’Toole, "No Democracy in Quality," 138. 
social sense ... And should we not trust that in almost any group there will be a fewperhaps only one-who will perceive the significance of a great expression? And if there is only one, wouldn't that justify an exhibit?57

Adams's optimistic belief that there existed an audience for fine art photography and that his photographs held social significance provides one rationale for why he suggested a panel exhibition of photographs on the theme of nature conservation to the Sierra Club. ${ }^{58}$ Undoubtedly, from the standpoint of an artist-photographer, Adams also saw the project TITAE as a creative outlet; a chance to exercise artistic control and show his work to an audience without the limitations of a commercial assignment. The exhibition TITAE would be important even if it made an impact on only one individual in the crowd, and its success would be measured by its ability to inspire social change and a new perception of the value of the American wilderness.

\subsection{NANCY NEWHALL}

By the 1950s, Nancy Newhall had gained extensive experience in designing and organizing exhibitions of photography from her time at MoMA and George Eastman House. In addition, Newhall had proven herself to be a gifted writer in her numerous articles and books on the American Southwest that she produced with Adams. To This Is the American Earth, which had a purpose of educating its audience, she would especially bring her skills as a writer and her approach to mediating the two creative forms of image-making and writing. In her 1952 article "The Caption: The Mutual Relation of Words/Photographs" in the first issue of Aperture, Newhall established a terminology to describe the different relationships between image and text on the printed page, introducing terms like "verbal equivalents," "narrative caption," "consecutive novel," and her preferred form, the "additive caption." 59 She defined the additive caption as the use of text to enhance the meaning of an image in a way that was "totally unexpected and unforeseen, which exists in neither words nor photographs, but only in their juxtaposition." 60 Newhall treated photographs and text as a unit, seeking an "interdependence" of the two mediums to establish a new form of communication she called "photo-writing." 61

\footnotetext{
${ }^{57}$ AA to Paul Strand, 31 October 1933, in Ansel Adams: Letters and Images, eds. Alinder and Stillman (Boston: Little Brown, 1988), 67.

${ }^{58}$ As one example of Adams's democratic use of the medium, he organized his photographs of Manzanar into a small panel exhibition with text, which he showed for one week in January 1944 at the internment camp. Alinder, Biography, 234.

${ }^{59}$ Newhall, "The Caption: The Mutual Relation of Words/Photographs," Aperture 1, no.1 (1952): 1729.

60 Ibid., 19.

61 Ibid.
} 
Newhall gained inspiration from her study of the photography books of that era that had a strong textual component. Important precursors to her idea of the additive caption included Dorothea Lange and Paul S. Taylor's An American Exodus (1939) and Wright Morris's The Inhabitants (1946).62 It was through a critical reading of these books as well as an in-depth examination of the illustrated press that Newhall developed her understanding of the relationship between image and text. Six years before she published "The Caption," she distilled her ideas in a review of Morris's The Inhabitants for Photo Notes published by the Photo League. ${ }^{63}$ In the review, Newhall wrote:

This is a book that every serious photographer should spend considerable time thinking about. It is an attempt, on a genuinely creative level, to fuse words and photographs into a new medium ... together, words and pictures search into the lives of their inhabitants ... What it is to be an American. Neither illustrates nor explains the other. The fusing happens-or doesn't happen-through the association of ideas in the mind of the beholder. 64

Newhall would have the opportunity to experiment with image and text herself in Time In New England with Paul Strand, a book on the history and character of New England. ${ }^{65}$ Strand also brought his particular opinions about words and photographs to the collaboration, and it is possible that he was an early influence on Newhall while she was still a member of the Photo League. In Strand's 1940 review of An America Exodus in Photo Notes, he wrote that in the book form "photographs must be the foundation material" while the role of text was to "heighten and extend their individual and total meaning." 66 Strand did not think that Lange and Taylor's book successfully achieved this heightened effect, and in a critique that sounds strikingly similar to Newhall's writing on the additive caption, he stated that there was a "tendency towards negation rather than an active interaction between image and word." 67 In Strand and Newhall's own book, Time In New England, the text did not directly illustrate the photographs, but introduced an element that could not be solely expressed by visual language. To evoke the presence of New England's early history in Strand's modernist photographs, Newhall selected a variety of historical writings including poetry, travelogues, and diary entries from the early New England settlers to accompany Strand's work.

${ }^{62}$ Newhall, "The Caption," 25, 28; Dorothea Lange and Paul S. Taylor, An American Exodus: A Record of Human Erosion (New York: Reynal and Hitchcock, 1939); Wright Morris, The Inhabitants (New York: Charles Scribner's Sons, 1946)

63 Nancy Newhall, review of The Inhabitants, by Wright Morris, Photo Notes, November 1946, 2. The Newhalls had first seen Morris's photographs for the book in New York in 1939, and Newhall wrote the review after he published the book in 1946. Wright Morris, introduction to The Inhabitants (New York: C. Scribner's Sons, 1946), 19.

${ }^{64}$ Newhall, review of The Inhabitants, by Wright Morris, Photo Notes, November 1946, 2.

65 Paul Strand and Nancy Newhall, Time In New England (New York: Oxford University Press, 1950).

${ }^{66}$ Paul Strand, review of An American Exodus, by Dorothea Lange and Paul S. Taylor, Photo Notes, March-April 1940.

67 Ibid. 
Newhall associated her theory of the additive caption to Stieglitz's "equivalents." Writing in the early 1940s, Newhall expressed:

It has been an extraordinary experience to observe how a different text or sequence or general context can change what people see and feel in the same photograph. Behind us all stands Stieglitz: without Equivalents and the sequence concept, both of which are beyond journalism, we might never have done what we have done. 68

Stieglitz never used text or language to accompany his photographs, since he religiously believed in photography's ability to transcend common forms of communication. Yet, Newhall, in her own way believed that she was making equivalents, and it certainly would have been a way to elevate her practice and place it within an esteemed tradition of art-making. Newhall's use of the additive caption is significant to an accurate reading of her work, which must equally address photographs and words. Her theory will inform the analysis sections of this thesis, which explore how the message and themes of both the book and exhibition This Is the American Earth emerged from an intentional fusion of image and text.

Furthermore, like Adams, Newhall believed in the transformative power of art in society. On the occasion of the publication of the book This Is the American Earth she wrote to Adams, "I think our job is to prepare for a new faith and a new world ... I think we do it by powerful words and images." 69 Newhall felt that photography had an important social role to fulfill and that it would solve the ills of society. In her review of the 1947 Jacob Riis exhibition at MoMA, organized by Adams, Newhall described the medium's capacity to be simultaneously expressive and functional, asserting, "This is what photography should be-an integrated creative and constructive statement."70 For Newhall, This Is the American Earth would not only deliver a conservation-themed message of the highest aesthetic order but would also be an agent of social change during a chaotic time in America.

${ }^{68}$ Nancy Newhall, "Notes for a biography on Stieglitz," unpublished manuscript, 131-132, AAA at CCP, quoted in Wilson-Powell, "An Eloquent Image," in Klochko, A Literacy of Images, 27.

${ }^{69}$ Nancy Newhall to Ansel Adams, 27 February 1950, quoted in Wilson-Powell, "An Eloquent Image," in Klochko, A Literacy of Images, 29. The date of the letter appears to have been transcribed incorrectly by Wilson-Powell since the essay stated that Newhall wrote to Adams "upon the publication of This Is the American Earth," which was not until January 1960.

${ }^{70}$ Nancy Newhall, review of the Jacob A. Riis exhibition, by Ansel Adams at the Museum of Modern Art, Photo Notes, November 1947, 2. 


\section{CHAPTER TWO}

\section{THE EXHIBITION THIS IS THE AMERICAN EARTH}

Many different goals and opinions had a role in shaping the concept and character of the exhibition This Is the American Earth throughout its curatorial development. This chapter will discuss each stage of the exhibition's planning and how the show came to reflect the viewpoints of Adams, Newhall, and the Sierra Club. As the curator, Newhall not only collaborated with Adams but actively sought the advice and assistance of people who were knowledgeable in the field of conservation, both experts and Sierra Club members. The breadth of her research led her to encounter conflicting perspectives, political motives, and personal agendas, which she struggled to mediate in her attempt to give an authentic presentation of the conservation concept. The second part of the chapter will describe the exhibition as it was fully realized, in detail never published before. Both photographs and text will be analyzed in terms of the concept of the additive caption to determine how each panel was a meaningful contribution to the whole. This will be followed by a discussion of the exhibition's reception both within the photography world and outside of it and how the perceived significance of the exhibition in large part was defined by its context of presentation during its tours under the Smithsonian and the USIA.

\subsection{PLANNING}

At a special meeting of the Sierra Club Lodge Committee in February 1954 called to discuss the NPS proposal for LeConte Lodge, Adams suggested transforming the lodge into an exhibition space and producing a photography exhibition that would fulfill the "need for public acquaintance with the Sierra Club its purposes and its relation of its principles to the preservation of the park and wilderness idea."1 A day later, at the Sierra Club Board of Directors meeting, the club's President Richard Leonard summarized Adams's presentation to the Lodge Committee as he put forth Adams's idea for an exhibition that would stress "what the Park Service really means to the country and to the whole conservation concept."2 It appears that Adams had artfully manoeuvred both sides of the equation as he suggested on one hand, that the exhibition find its focus in the Sierra Club, and later stated that the exhibition would express the importance of the NPS. Whether or not this was

\footnotetext{
${ }^{1}$ Quarterly meeting minutes of the Sierra Club Board of Directors, 27 February 1954, page 7, Sierra Club Board of Directors Meeting Minutes 1954-1955, Bancroft Library, http://content.cdlib.org /ark:/28722/bk000786x9c/?order=5\&brand=calisphere.
}

${ }^{2}$ Ibid. 
Adams's intention, he had found a way to save the club's lodge and the NPS approved of the proposal, following with a renewal of the club's lease a few months later in June. From the outset, the exhibition was designed to be a travelling panel exhibition, produced with funds from Sierra Club member Walter Starr. ${ }^{3}$

In April 1954, Newhall began to conduct research, contact photographers, and draft the panels for the show. ${ }^{4}$ Initially, Adams and Newhall decided that the exhibition would be a "nation-wide interpretation of conservation problems in an expressive form." ${ }^{5}$ In an early undated plan for the exhibition labelled "tentative," Adams and Newhall envisioned twelve panels and outlined them as follows:

\section{Affirmation, Elements of Nature}

2. History and Leaders of Conservation

3. Examples of Appropriate Use, Recreation

4. The National Forests and Reclamation Projects

5. Wilderness Areas and Wildlife

6. Historic Preserves and National Monuments

7. The National Parks

8. National Parks - protection and respect for

9. National Park Service - responsibilities, interpretation, and education

10. Hetch-Hetchy - demonstration of wrong use

11. Conservation organizations and their function

12. Conservation and the future 6

From this preliminary list of panel topics, it is clear that the exhibition was tailored to educating an American audience about its nation's parklands and the agencies that maintained them. However, in just a month's time, Newhall and Adams had broadened the concept of the show to present conservation as it could be applied to "the whole earth and its wise use."7 Overwhelmed by her

${ }^{3}$ Undated draft of exhibition outline, folder "This Is the American Earth (Exhibit)," NN at CCP.

${ }^{4}$ Nancy Newhall to Adams [hereafter cited as NN to AA], "Project Priority List," 28 April 1954, Ansel Adams Archive at the Center for Creative Photography [hereafter cited as AAA at CCP].

${ }^{5} \mathrm{NN}$ to AA, 28 April 1954, AAA at CCP, quoted in Anne Hammond, Ansel Adams: Divine Performance (London; New York: Yale University Press, 2002), 113.

${ }^{6}$ Undated correspondence, AAA at CCP.

${ }^{7} \mathrm{NN}$ to AA, 12 May 1954, AAA at CCP. 
copious discoveries through her research into the history of America's conservation movement, Newhall wrote to Adams, "I must be judge and jury over what amounts to the history of the world and its projections onto the future, over the history and dynamics of America, over the claims of such as Vogt and Osborn.... Stephen and Muir and Pinchot must be there too, and the ancient crucial and unnecessary battle between USE and Preservation."8 Newhall recognized the distinction between the two interpretations of conservation-use and preservation-yet at the time, there was no single, definitive approach to balancing the conflicting objectives.

Hammond's research on the exhibition TITAE reveals differing opinions on the definition of conservation between two particular stakeholders of the project. Newhall sought advice from the writer and conservationist Bernard De Voto who frequently criticized the government's use of natural resources and urged Americans to protect their national parks in his column "The Easy Chair," which regularly appeared in Harper's magazine. As Hammond writes, upon reading the first draft of the exhibition text in August 1954, De Voto "cautioned Newhall to scrutinize carefully any passage in her text suggesting that the value of birds and glaciers might somehow outweigh the value of people, the most important part of the ecological whole."9 To De Voto, environmental devastation needed to be framed in terms of social consequences, and in his column, he contended that the government's exploitation of natural resources was a threat to the well-being and "sovereign rights" of its citizens. ${ }^{10}$ This particular article was written to oppose the Bureau of Reclamation's 1946 proposal to the NPS to build the Echo Park dams. Although the bureau believed that the reservoir would provide citizens with beneficial recreational opportunities, De Voto did not agree with any kind of development that would alter the primeval beauty of the parks, which he argued, was inextricably linked to the rights of future Americans to experience their nation's wilderness. ${ }^{11}$ The Sierra Club member George Marshall viewed a different purpose for the exhibition. He thought that it should focus on conveying the beauty and spiritual value of the national parks, and he was otherwise uncertain as to how the exhibition would be able to describe the complexities of resource conservation. Yet, he felt certain that if the exhibition was going to present dams, it would have to argue that they did not belong in the National Parks. ${ }^{12}$

\footnotetext{
${ }^{8} \mathrm{NN}$ to AA, 20 June 1954, AAA at CCP.

${ }^{9}$ Hammond, Divine Performance, 125.

10 Bernard De Voto, "Shall We Let Them Ruin Our National Parks," Harper's, 22 July 1950, 17.

${ }^{11}$ Kevin Wehr, America's Fight Over Water: The Environmental and Political Effects of Large-Scale Water Systems (London: Routledge, 2004), 162-63.

12 George Marshall to NN, 8 May 1954, AAA at CCP, cited in Hammond, Divine Performance, 125.
} 
At the time, the Sierra Club was indeed opposing the NPS's cooperation with the Bureau of Reclamation on its proposal to build the Echo Park dams through Dinosaur National Monument. While drafting the exhibition panels, Newhall was aware that the exhibition would have to somehow further the club's campaign against the proposed dam and increase its influence on forthcoming legislature. In the press release for the exhibition's opening, the Sierra Club openly stated its intent to "strengthen public opinion on the importance of protection and preservation of the National Parks and the remaining wilderness," and Newhall would specifically devote Panel Five to rallying against the Echo Park dam. ${ }^{13}$ Wisely navigating the controversies over the meaning of conservation, Newhall was careful not to lean too far on either side; she neither rejected dams nor promoted their development for human benefit. In Panel Five she explained that dams required proper planning and that some sites were more suitable than others. Dams could "open new lands and create new hopes," she wrote, but it was senseless to destroy a unique wilderness habitat when better solutions could be found.

Newhall's struggle to decipher "use and preservation" represented a larger difference between two conflicting viewpoints of the human relationship to the wilderness, which can be labelled as anthropocentrism and ecocentrism. De Voto favored an anthropocentric view, advising Newhall that humans occupied the highest position in the natural order. Marshall seemed to fall somewhere in the middle, not entirely persuaded that nature should be assigned a value based on human benefit. Spaulding covers this conceptual territory in greater depth in his biography of Adams. ${ }^{14} \mathrm{He}$ identified the roots of ecocentrism in the writing of wildlife biologist Aldo Leopold who, like Muir, understood the ecological value of nature. ${ }^{15}$ As Spaulding summarized, Leopold "called for a land ethic founded on the realization that the environment was a community to which humanity belonged rather than a community that it possessed." 16 While the Sierra Club was moving towards a more ecocentric concept of the wilderness in the 1950s, especially with its participation in the newly founded Wilderness Conferences, on the whole, the Sierra Club's activities and campaigns in the post-war years were still based on an anthropocentric relationship to the wilderness. ${ }^{17}$

${ }^{13}$ Press release by Adams, 7 April 1955, AAA at CCP.

${ }^{14}$ Jonathan Spaulding, Ansel Adams and the American Landscape: A Biography (Berkeley: University of California Press, 1995), 286-291. Where Spaulding uses the term biocentric, this thesis uses the term ecocentric in a synonymous way. The differences between the two schools of thought have thus far been illdefined and remain outside the scope of this thesis.

${ }^{15}$ Spaulding, Biography, 288.

16 Ibid.

17 Ibid., 286. 
Deciding which approach to take in the exhibition was a dilemma for Newhall. In a letter to Adams in September 1954, she was eager to resolve whether the overall message should be anthropocentric or ecocentric. On one hand, she felt that man was an equal part of nature, rather than "the highest expression of it."18 On the other hand, she believed that man was a more evolved form that had accomplished things "beyond the furthest possible reach of our hands and imaginations." 19 Adams replied with a list of "Sierra Club safe assumptions" that implicitly directed Newhall toward an anthropocentric approach:

1. Man's improvement is the objective, his estate and spirituality

2. Natural scene is a resource of inspiration, evidence of God in the simplest and most essence

3. Conservation is about preserving resources for Man's benefit

4. National Parks are key, and wilderness ${ }^{20}$

It is unclear whether Adams's list accurately represented the club's principles. Judging by the list, it seems that he was expressing a particular view of the wilderness that stemmed from his monistic belief system, which he developed from exposure to nature literature and theosophy during his twenties. Hammond's book covers this period in Adams's life extensively, and examines the plethora of artistic, familial, and literary figures that influenced his ideas about his relationship to the universe. As Hammond explained, in August 1925, Adams read Edward Carpenter's book Towards Democracy, and became deeply influenced by Carpenter's call for, what Hammond defined, as the "return to the good relation of human being to human being, and of human beings to nature."21 Adams's photographic practice grew to reflect Carpenter's ideas among those of other nature writers, and through his mountain experiences he gained a more holistic view of nature than most Sierra Club members. Hammond described this view as Adams's belief in the "unity of all material and spiritual things in an Absolute One and the possibility of the self's ultimate union with that whole."22

Newhall was also deeply influenced by the philosophy put forth by Edward Carpenter. However, she came to understand his theories through another important Sierra Club member, Cedric Wright. While drafting the TITAE exhibition panels in August 1954, she brainstormed several ideas

18 NN to AA, 9 September 1954, AAA at CCP.

19 Ibid.

20 AA to NN, 19 September 1954, AAA at CCP.

${ }^{21}$ Hammond, Divine Performance, 8.

22 Linda Dalrymple Henderson, "Mysticism, Romanticism and the Fourth Dimension," in The Spiritual in Art: Abstract Painting 1890-1985, ed. Maurice Tuchman (Los Angeles: Los Angeles County Museum of Art; New York: Abbeville Press, 1996), 222, quoted in Hammond, Divine Performance, 8. 
for the show in a letter to Adams, and exclaimed, "It's due to working on [Cedric's] book that I got into this. So many of his conclusions are wonderful while his supporting arguments ain't there!"23 As mentioned previously, Adams had asked Newhall to edit Wright's manuscript Words of the Earth in 1949. Newhall selected excerpts from his writings and paired them with his photographs in a book dummy, yet the work was not published by the Sierra Club until over ten years later, after Wright's death. Words of the Earth was a significant milestone for Newhall, and both her poetic style of writing as well as her ideas for the exhibition and book TITAE reflect Wright's manuscript.

In the exhibition, Newhall incorporated Wright's philosophies into Panel Seven and Ten. She did not quote him directly, but her phrases vividly echoed many of his poetic descriptions of the wilderness, reflecting Wright's keen ecological awareness. To balance Wright's views, adjoining panels presented a more anthropocentric perspective. For example, Panel Six gave a factual description of how to improve farming methods and maximize timber supply through monitoring, research, and private ownership of forest tracts. This was perhaps Newhall's way to mediate the two conservation perspectives. Regardless, at the core of the exhibition was Newhall's conviction that preserving the wilderness served a greater social purpose. Ultimately, the exhibition was not only for the Sierra Club, but for the whole world. In 1954, Wright had expressed a similar feeling in a prefatory note to one of his manuscripts. He wrote,

I have been unusually privileged in knowing intimately those wilderness areas where the intangible values sing clearly... The artist seeks fundamental beauty, the voice of concord, in a world which is presently dominated by opposite types of understanding. Beauty and understanding are the foundations not only of art, but also of a peaceful human world. It is imperative that in such times as these the artist should use his words and thoughts in addition to his art. ${ }^{24}$

Although not explicitly stated as a purpose of the exhibition, Newhall felt that the union of words and photographs would inspire understanding in a time of global conflict.

\subsection{PRESENTATION}

Newhall also had much to consider when choosing photographs. The photo selection for the exhibition This Is the American Earth was an assortment of work that included straight photography, survey photography, and photojournalism, as well as historic photographs from the George Eastman House collection. Adams's photographs were drawn primarily from his work for

${ }^{23} \mathrm{NN}$ to AA, 3 August 1954, AAA at CCP.

${ }^{24}$ David Brower, publisher's note to Words of the Earth, Exhibit Format Series 2, ed. Nancy Newhall (San Francisco: Sierra Club Books, 1960). 
the Department of the Interior in 1941 and 1942, as well as work made during his Guggenheim Fellowship. ${ }^{25}$ Newhall was particularly displeased with the survey photographs from the U.S. Forest Service, which she felt were useful for their informative value but looked too "pedestrian or documentary." 26 She arrived at the same conclusion in her search for wildlife photographs, with the exception of Eliot Porter's work. ${ }^{27}$ By December 1954, Newhall had drawn up a list of photographs to be borrowed from the George Eastman House, and early in 1955 she sent print requests to Porter, Margaret Bourke-White at Life magazine, Arthur Rothstein at Look magazine, and Henri Cartier-Bresson at Magnum Photos. ${ }^{28}$

While the informative content of the exhibition was of utmost importance to Newhall, she also aimed to present a panel exhibition that was on par with the display of photography in the art museum. Newhall requested that the photographers send their negatives to Adams to print, as it would enable them to more easily size the prints to fit each panel and would also ensure a consistently high print quality. ${ }^{29}$ Despite Newhall's opinion that photographers should have control over the printing of their negatives, she had to manage a wide variety of photographs, many of which had been made exclusively for the illustrated press and were never intended to be displayed as fine photographic prints. Therefore, excluding eight negatives from the work of six different photographers, the entire show was printed by Adams with assistance from his student Pirkle Jones. ${ }^{30}$ Newhall also expressed her wish for the photographs to be protected with mats and cover glass, which she believed added dignity to the individual print. ${ }^{31}$ However, this was never realized, as it was not practical for the limited space of each panel and the exhibition's travel. ${ }^{32}$ In addition to photographs, Newhall decided to include small natural objects as accents of color and to give the

${ }^{25}$ Hammond, Divine Performance, 114.

${ }^{26} \mathrm{NN}$ to AA, 9 September 1954, AAA at CCP.

$27 \mathrm{NN}$ to AA, 21 June 1954, AAA at CCP.

28 "Lent to Sierra Club," typed list, 7 December 1954, with notations made by Newhall on 24 March 1955. Newhall's selection may have been influenced in part by Edward Steichen's selection for The Family of Man exhibition, which she had seen at MoMA in January 1955. Three of the 103 photographs she ultimately chose for TITAE were also in The Family of Man - Cartier-Bresson's Mohammedan Women Praying at Sunrise, Bischof's Famine, India, and Morgan's Girl With Recorder. However, Newhall was well acquainted with these photographers and it is possible that she simply chose the best images for her purpose, like Steichen.

${ }^{29} \mathrm{NN}$ to AA, 20 June 1954; 21 June 1954, AAA at CCP.

30 Unidentified author, "Close-Up on Nature," Modern Photography, November 1955, 89. There is no mention of Pirkle Jones's involvement in the exhibition in any other primary or secondary source.

Featherstone's essay stated that Brett Weston refused to have his negatives printed by Adams. "This Is the American Earth: A Collaboration by Ansel Adams and Nancy Newhall," in Ansel Adams New Light: Essays on his Legacy and Legend, ed. Michael Read (Carmel: Friends of Photography, 1993), 67.

${ }^{31} \mathrm{NN}$ to AA, 20 June 1954, AAA at CCP.

32 Ibid. 
show what she called a "sculptural quality." 33 The final exhibition panels included six objects— two butterfly specimens, a fifth-century Greek terracotta figurine of a woman, a sixth-century Greek marble head of a man, a coral mushroom, and a cluster of rock minerals. ${ }^{34}$

The exhibition This Is the American Earth was shown at the California Academy of Sciences from May 6 to June 5, 1955, and travelled to the LeConte Memorial Lodge in Yosemite Valley in the last week of June for the summer. ${ }^{35}$ Although Hammond contends that it was a duplicate copy of the exhibition that travelled to LeConte Lodge in June, Adams's correspondence with the Sierra Club in April 1955 clearly stated that the original version of the exhibition would be shown at the Lodge. ${ }^{36}$ The exhibition consisted of fourteen panels, each measuring forty inches high by seven feet, displaying a total of 103 photographs. ${ }^{37}$ The photographs were primarily landscapes and nature studies, and they were accompanied by Newhall's narrative text. Each panel displayed a range of six to eighteen photographs in varying sizes, placed in an irregular arrangement with some photographs overlapping one another. Fifty-four of the photographs were taken by Adams, and the remaining forty-nine were taken by other photographers and gathered from institutions, magazines, agencies, collectors, and the photographers themselves. ${ }^{38}$ The photographs were drymounted on grey Masonite panels, and the whole assembly was sprayed with a protective clear lacquer. ${ }^{39}$ Newhall's labels were extensive and they formed a loosely chronological narrative that integrated historical and scientific facts about the American conservation movement. She combined her own writing with excerpts from a variety of literary sources, and although her style was poetic at times, in general the labels presented dense factual information. At the LeConte Lodge, the

${ }^{33} \mathrm{NN}$ to AA, 3 August 1954, AAA at CCP.

34 Three of the six objects were borrowed from the de Young Museum in San Francisco. Gladys E. Acton, Assistant to Chief Travelling Exhibition Services at the Smithsonian to Edith McLellan, Registrar at the M.H. de Young Museum, 6 July 1959, AAA at CCP. Adams had an existing relationship with the de Young Museum who had given him his first solo exhibition in 1932. Alinder, Biography, 32.

${ }^{35}$ AA to Sierra Club Executive Committee, 4 April 1955, AAA at CCP. The date of the exhibition is incorrectly stated as May 8, 1955 in Featherstone, "A Collaboration," 67.

${ }^{36}$ AA to Sierra Club Executive Committee, 4 April 1955, AAA at CCP.

${ }^{37}$ Newhall provides the panel specifications in NN to AA, 3 August 1954. The measurements are incorrectly stated as "seven feet by four feet," in Featherstone, "A Collaboration," 67 and in Sierra Club promotional material. In addition, there seem to be conflicting counts on the number of photographs in the exhibition. Featherstone and Hammond count 102 photographs. Alinder counts 103 photographs; cf. "A Collaboration," 67; Divine Performance, 114; Biography, 253. The author's count is based on the photographic slide reproductions of the exhibition panels as well as the corresponding "This Is the American Earth, List of Photographs," 8 August 1956, AAA at CCP. The list has 104 objects, but excluding the James Audubon lithograph, only 103 objects are photographs.

${ }^{38}$ See Appendix A for a complete list of contributing photographers, collectors, and institutions.

${ }^{39}$ Unidentified to Mr. Tose at the California Academy of Sciences, 2 March 1955, AAA at CCP. 
exhibition was accompanied by music and an exhibition leaflet which outlined the sequence of the exhibition and its overall purpose. ${ }^{40}$

Out of the fourteen panels, three were not designed by Adams and Newhall. The architect, Eldridge "Ted" Spencer, coordinated the production of these panels and also organized the layout of the panels in the LeConte Lodge. Spencer was a close friend of Adams, and together they had established a photography department at the California School of Fine Arts in 1945. Spencer created a panel that included three photographs by Adams, a large map of Yosemite Valley illustrated by the artist Samuel Provenzano, and a text on planning infrastructure in Yosemite National Park. The other two panels were designed and painted by Spencer's daughter Frann Spencer Reynolds with text by her husband, the geographer Richard Reynolds on the "Redman's Sierra Nevada" and the "Whiteman's Sierra Nevada." 41

An exact duplicate copy of the exhibition was made specifically for circulation, and it was assembled after the exhibition's opening at the California Academy of Sciences. ${ }^{42}$ Under sponsorship from the Sierra Club, the duplicate travelled to the Stanford University Library in 1955.43 Adams and Newhall then arranged for the Smithsonian Institution to continue the exhibition's tour over the next three years. Hammond stated that Newhall contacted the director of the Smithsonian's Traveling Exhibitions Service, Annemarie Henle Pope, as early as January 1955, regarding the possibility of touring TITAE. ${ }^{44}$ However, correspondence located at the Smithsonian Institution Archives suggests otherwise. It seems that Newhall made contact with the Smithsonian around January 1956, the following year, according to a note from Henle Pope to the Smithsonian's

\footnotetext{
${ }^{40}$ Brower to Adams, 27 September 1956, in Ansel Adams: Letters and Images, 1916-1984 (Boston: Little, Brown, and Company, 1988), 238; Undated exhibition leaflet, "Sequence of the Exhibit," folder "This Is the American Earth at LeConte Lodge, 1954," AAA at CCP.

${ }^{41}$ Undated exhibition leaflet, "Sequence of the Exhibit," folder "This Is the American Earth at LeConte Lodge, 1954," AAA at CCP.

42 AA to Sierra Club Executive Committee, 4 April 1955, AAA at CCP.

${ }^{43}$ W. B. Ready, Acting Librarian at Stanford University to Eldridge T. Spencer, 9 November 1955, AAA at CCP.

${ }^{44}$ Hammond, Divine Performance, 114.
} 
director, Thomas Beggs. ${ }^{45}$ In addition, contrary to Hammond's research, the Smithsonian only toured one copy of the exhibition beginning in 1956 — not both copies — while the original version stayed at LeConte Lodge. ${ }^{46}$ This fact is confirmed by a letter that Brower wrote to Adams in 1956, indicating that he and his wife, Anne, had stopped into the LeConte Memorial Lodge and that Anne was especially moved "by the LeConte exhibit." 47 Thus, from 1956 to 1959, one copy of TITAE was circulated by the Smithsonian Institution to local museums, science museums, and universities across the United States, while one copy remained on display in the LeConte Lodge. ${ }^{48}$

Finding the exhibition TITAE listed in the Smithsonian's catalogue, the United States Information Agency requested four additional copies of TITAE to be produced and circulated worldwide.49 Through the unusually meticulous recordkeeping of the Smithsonian Institution's Traveling Exhibitions Service, as well as through the congratulatory correspondence from friends of Adams and Newhall, it has been possible to reconstruct most of TITAE's national tour. However, a record of venues for the international tour appears to only exist in pieces. ${ }^{50}$ The Smithsonian's copy of TITAE returned to the California Academy of Sciences from its national tour in March 1959 in poor condition, and in 1963 it was disassembled for the prints that could be salvaged for a new LeConte Lodge exhibition, which is an important extension of TITAE, but is beyond the scope of this thesis. ${ }^{51}$ The fate of the USIA's four duplicates of TITAE is uncertain. Judging by the condition of the Smithsonian's copy, it is likely that the international tour left the four duplicates in worse condition, and with the USIA financially backing the production of the four copies, it is quite likely that the

45 Annemarie Henle Pope to Thomas Beggs, 17 January 1956, collection 290, box 58, folder 11, Smithsonian Institution Archives. Annemarie Henle Pope wrote, "The George Eastman House in Rochester has offered us an exhibition consisting of mounted photographs by Ansel Adams, Brett Weston, and many other famous photographers, and text by a number of authorities in the field of conservation... Do we have your permission to accept this show for circulation?" The Smithsonian arranged for exhibitions of primarily fine art to travel to museums, elementary and secondary schools, libraries, colleges, art schools, and universities. The department and program was started in 1951 by Annemarie Henle Pope. "Art on the Road," Radcliffe Quarterly (May 1961), AAA at CCP.

${ }^{46}$ AA to Brower, 1 July 1956, Sierra Club Office of the Executive Director Records, BANC MSS 2002/230c, carton 21, folder 42, Bancroft Library. Hammond incorrectly concluded that "Both sets [of the exhibition] were toured nationally by the Smithsonian Institution." Divine Performance, 114.

${ }^{47}$ Brower to AA, 27 September 1956, in Ansel Adams Letters and Images 1916-1984, eds. Mary Street Alinder and Andrea Gray Stillman (Boston: Little, Brown and Company, 1988), 238-40.

48 Undated itinerary, "This Is the American Earth: Itinerary," Smithsonian Institution Archives. See Appendix C for the itinerary for the exhibition's national tour.

${ }^{49}$ Annemarie Henle Pope to Thomas Beggs, "New U.S.I.A. contract," 12 July 1956, Smithsonian Institution Archives.

${ }^{50}$ See Appendix C for the itinerary for the exhibition's international tour.

${ }^{51}$ Annemarie Henle Pope to NN, 5 February 1959; AA to Sierra Club, 9 September 1964, AAA at CCP. 
panels never returned to the Sierra Club or travelled back to the United States. ${ }^{52}$ The original TITAE exhibition remained at the LeConte Lodge until 1962, at which point it had severely deteriorated and Adams called for it to be "junked."53

\subsection{DESCRIPTION AND ANALYSIS}

This section of the thesis will describe, in detail, the content of the exhibition. It will begin by outlining the exhibition's layout and will also provide a general overview of its narrative. In greater detail, it will analyze the photographs and text in each of the fourteen panels to determine the exhibition's message and to establish how Newhall combined words and photographs to compose a persuasive argument on nature conservation.

Information regarding the sequence of the fourteen panels is scattered among several primary documents, and based on discrepancies between the documents, it appears that the panel sequence varied according to the exhibition venue. Therefore, the author will present the sequence of the exhibition for its permanent display in LeConte Lodge. This arrangement has been determined from the author's examination of three documents. These include a typed leaflet with panel numbers and directions that accompanied the exhibition at LeConte Lodge, Newhall's sketch of the panel arrangement on an architectural plan of LeConte Lodge, and the manuscript for the exhibition text. 54

Upon entering LeConte Lodge, viewers encountered a row of panels along the right and left side of the room arranged in a slight zig-zag formation. Viewers were offered a leaflet at the entrance that directed them to start on the left side of the room and follow the subsequent six inner panels, which brought them back to the entrance on the opposite side of the room. Then, they were instructed to walk around the outer edges of the room to view the remaining eight panels. Viewers of the exhibition, if they followed the prescribed sequence, were led through a lyrical combination of

\footnotetext{
52 Adams wrote, "There is no financial obligation whatever on the part of the Sierra Club and/or the California Academy of Sciences. Full credit will be given both organizations both in the exhibits and in publicity." AA to Brower, 1 July 1956, Sierra Club Office of the Executive Director Records, carton 21, folder 42, Bancroft Library.

${ }^{53}$ AA to Walter Starr, 23 August 1962, Sierra Club Members Papers, BANC MSS 71/295c, carton 2, folder 41, Bancroft Library.

54 Undated exhibition leaflet, "Sequence of the Exhibit," folder "This Is the American Earth at LeConte Lodge, 1954," AAA at CCP; Architectural plan, "Possible Sequence for TITAE," signed by NN, 25 March 1955, folder "LeConte Lodge 1954," AAA at CCP; Undated draft of exhibition text, "Master Text / File Copy," Sierra Club Office of the Executive Director, carton 21, folder 43, Bancroft Library.
} 
photographs and text that delivered an uplifting narrative on the wealth of America's natural resources and the history of the American conservation movement. The exhibition began with a prelude that conveyed the spiritual qualities of the wilderness. At the core of the exhibition, panels were organized thematically to show different aspects of natural resource management and use in America. There were panels on America's first settlers, the national parks, leaders in the conservation movement, proper and improper use of dams, the role of federal agencies in managing natural resources, the inspirational value of the national parks, and the wilderness as the origin of American democracy. Near the end of the exhibition, this dense thematic exposition tapered to a quiet statement on the spiritual value of undisturbed wilderness, and the exhibition ended on a promising note about the bright future of America and its people living in harmony with the land.

\section{Panel One $e^{55}$}

The exhibition opened with Adams's photograph Sierra Nevada from Lone Pine, positioned on the far left side of the first panel. Serving as the title photograph, it is a panoramic view printed in a relatively large size, to occupy a third of the panel with "This Is the American Earth" on a label in bold typeface directly below it. Newhall's first label below the title read, "This, as citizens of the United States, we all inherit. / This is ours to love and live upon, and use wisely down all the generations of the future." In this introduction, Newhall characterized nature in anthropocentric terms, as human property that is meant to be owned, transferred, and used. As Hammond has pointed out, Newhall's verse evoked the American narrative of Manifest Destiny, borrowing from the third beatitude of the New Testament, in which God bestowed the inheritance of the earth to his followers. ${ }^{56}$ Alongside this text, Adams's photograph of an empty Sierra Nevadan landscape, with the exception of a dotting of trees and a grazing animal, became an image of the American frontier - a place of wild terrain, an untouched Garden of Eden, and an abundance of available land with the opportunity for expansion.

The first panel continued to qualify the earth's resources in terms of their physical benefits to humans, as the next label read, "Always there must be water brought to the dry land, rich earth for ploughing ... fish in the seas and streams" to eat, and "timber in the hills" to build shelters. However, to the right of Sierra Nevada from Lone Pine, Adams's photograph Nevada Fall, Yosemite

\footnotetext{
55 For the analysis of the panels, readers may wish to refer to Appendix D, which includes an exhibition checklist with reference images and dates of photographs.

${ }^{56}$ Hammond, Divine Performance, 118.
} 
National Park, juxtaposed with a delicate butterfly specimen mounted to the panel in a small case, presented a wholly different argument about the value of the wilderness. Below the pairing of a butterfly and a photograph of an immense waterfall, Newhall's label in bold typeface posed the question, "WHAT IS THE PRICE OF EXALTATION?"57 Through the trio of image, object, and text, Newhall suggested that nature's true value is intangible, in its capacity to excite and inspire human emotion. As the exhibition text continued, the next label turned to convey a negative scene that lacked any trace of the natural environment:

... AN AGE DARKENING WITH FEAR -

- an age of crowds and crowding

- an age where half the populations of the earth are cowed by terror and no man among them dares walk or think alone."

Yet, none of the photographs on the panel illustrated this dark mood and disheartening modern environment. Instead, nearby, Nevada Fall and the butterfly specimen are presented as solutions — a moment of exaltation and individual experience — in a busy and spiritually unfulfilling modern world. Additionally, Newhall arranged the photograph and object in a way that allows the viewer to simultaneously behold the immensity of water and minute details of the insect to visually reproduce Adams's and Wright's unique perception of nature, which they termed "mountain experiences." Hammond astutely described this viewpoint as "an inclusive perception of things, mountain immensities and tiny particularities of detail seen all at once."58

Newhall continued to argue for the spiritual benefits of nature through two pairings of photographs that share the contrasting arrangement of the butterfly and waterfall. Near the bottom of the panel, Newhall juxtaposed Adams's photograph Lake MacDonald, Evening, Glacier National Monument with a close-up of foliage in his Fern and Leaves, Dew, Mount Rainier National Monument. With the accompanying label asking, "WHAT IS THE VALUE OF SOLITUDE? - OF PEACE, OF LIGHT, OF SILENCE," the two photographs came to represent the stillness of nature. Building to its third question, Newhall's label asked, "WHAT IS THE WORTH OF EXPERIENCE THAT WIDENS AND LIGHTENS OUR HORIZONS?" What Newhall suggested is that nature can enhance and illuminate man's "horizons" - his individual prospects, ambitions, and limits. Reinforcing this message, nearby, the final pairing of photographs captured the way the sun illuminates a dark mass to reveal its

${ }^{57}$ All capitalization and punctuation belong to Newhall's exhibition text. Newhall frequently used capitalization to indicate sub-headings or thematic phrases. The use of ellipses belongs to the author. ${ }^{58}$ Hammond, Divine Performance, 54. 
unique form in Adams's Cholla, Noon, Organ Pipe National Monument and Midnight Sun, Glacier Bay National Monument.

At the outset of the exhibition, Newhall formed a quiet dialogue between words and photographs. Her labels encouraged a reflective mood while subtly establishing that the American wilderness contains spiritual value. The panel conveyed the wilderness as a site of relief from the modern world, and assured the viewer that nature is a place where human emotion, thought, individuality, and spirit will be nurtured by an atmosphere of natural beauty and solitude.

\section{Panel Two}

While the first panel presented the viewer with the possibility of an emotionally rewarding relationship with nature, the second panel argued that throughout history, humans have not always sought or sustained this kind of relationship, causing harm to both themselves and their environment. To introduce a protagonist into the narrative, Newhall opened Panel Two with a small unembellished figurine of a woman, and her first label celebrated the appearance of the human race on the planet, declaring, "Out of the vast depths of time past, man is a comet rising." 59 Newhall selected the photograph Halley's Comet to directly illustrate the text, and through this pairing, she expressed that mankind's creation was a momentous and brilliant episode in earth's history. ${ }^{60}$ Her label continued to chronicle the early history of humans by combining scientific fact with mythology: "TWO BILLION YEARS AGO THE EARTH COLLED [sic] FROM FIRE AND CLOUD / Was it a million years ago when the first man stood upright and walked with both hands free? /- when with primordial tools and the great tool fire [sic], did man in all continents begin to influence life upon the earth?"

The remainder of the panel was decidedly less positive. From Spain to Northern Mongolia, Newhall presented nine accounts of the ways early human civilizations, across the globe, wasted the land in the process of sustaining their survival. Although the exhibition primarily focussed on American

${ }^{59}$ Where Newhall uses "man," she is referring to the whole of humanity. In this thesis' analysis of the exhibition, it adopts Newhall's use of "man" and "mankind" to evoke the universality of her narrative.

${ }^{60}$ Halley's Comet was photographed from Lick Observatory over ninety-five nights from September 12, 1909 to July 7, 1910, producing a total of 370 negatives. In the observatory's publication of its Halley's Comet photographs, the comet is plummeting towards or across the earth rather than in a steep upward direction. Thus, it seems that Newhall manipulated the orientation of the photograph to align with the uplifting tone of the text. Heber D. Curtis, Photographs of Halley's Comet Made at Lick Observatory (June 1, 1910), Astronomical Society of the Pacific 22, https://archive.org/details/jstor-40691710. 
themes, this panel reflected Newhall's interest in the larger global history of conservation. Her approach is remarkably similar to that of the New England writer George Perkins Marsh in his seminal text Man and Nature, first published in 1864.61 Indeed in the rough drafts of Newhall's exhibition text, Marsh's name appears in the handwritten mark-up. ${ }^{62}$ In the foreword to the book George Perkins Marsh: Prophet in Conservation, William Cronan remarked that Marsh used "world history as a tool for trying to imagine how environmental degradation might affect the United States."63 Marsh concluded that the "great civilizations of antiquity had disappeared ... because they abused the natural environments on which their own prosperity depended." 64

Newhall arrived at the same conclusion as Marsh, her label proclaiming, "ALREADY, BEHIND US, ACROSS THE CONTINENTS THE RECORD OF RUIN LIES VERY OLD." In this context, the meaning of Halley's Comet shifted from a celebration of man's creation to an omen of disaster. With limited panel space, Newhall chose photographs to illustrate only four of the nine accounts of environmental devastation described in her exhibition text. Beginning with China, Newhall selected a survey photograph of China's Shanxi province in 1903, depicting a bleak hill of rock and dirt.65 The label conveyed that this barren site was caused by deforestation, and while humans are not included in the photograph, Newhall's text also described how the loss of forests led to severe floods that ended the lives of millions of people. ${ }^{66}$ Newhall positioned the photograph of China directly adjacent to a photograph of starving elderly people huddled closely together in Famine, India, taken on assignment by Werner Bischof during the 1951 famine in Bihar. While Newhall's label revealed that famine was the result of India's improper use of land—-rich and

\footnotetext{
${ }^{61}$ George Marsh, Man and Nature (Cambridge: Belknap Press, 1864). See Appendix B for a complete list of the literary sources that Newhall directly quoted and also may have referenced in her exhibition text.

${ }^{62}$ Undated draft of exhibition text, NN at CCP. Beside the typed text, "A New Ethic was being born," for Panel Four, the handwritten mark-up read, "this comes from Marsh." However, the notation is not in Newhall's script. It is also an inaccurate note since the "new ethic" that Newhall referred to in Panel Four is more likely "the land ethic" defined by Aldo Leopold in his 1949 book A Sand County Almanac.

63 William Cronan, foreword to George Perkins Marsh: Prophet in Conservation by David Lowenthal (Washington: University of Washington Press, 2009), $\mathrm{x}$.

64 Ibid.

65 Undated loose photographs, folder AG31:2:4:26, AAA at CCP.

${ }^{66}$ For her text on China, Newhall appears to have exaggerated the negative effect by combining several disastrous episodes into one episode. Flooding of the Yellow River resulting in deaths was a separate event from Shanxi deforestation, and it occurred several times throughout history, in 1887, 1931 , and 1938. Encyclopaedia Britannica, Huang He Floods, http://www.britannica.com/EBchecked/topic/1483621/HuangHe-floods. The exact source of Newhall's research on China has not been determined. However, her description closely corresponds to Norman Shaw's 1914 account of deforestation in Taiyuanfu, Shanxi province, China. Chinese Forest Trees and Timber Supply (London: T. Fisher Unwin, 1914), 125, quoted in Robert B. Marks, China: Its Environment and History (New York: Rowman and Littlefield, 2011), 233.
} 
wasted"-Bischof's photograph solely emphasized the human consequence of overusing natural resources.

At the middle of the panel, Newhall continued to argue that throughout history, the clearing of land for resources led to human suffering and death. Newhall presented two examples from ancient Palestine and Greece, selecting an excerpt from the ancient text the Dialogues of Critias, written by Plato in $360 \mathrm{BC}$, as an eyewitness account of environmental ruin in Greece. Since these ancient events pre-dated photography as a commercialized medium, Newhall creatively repurposed two nineteenth-century travel photographs of ancient ruins_- Tomb of Absalom, Palestine by an unidentified photographer and James Robertson's The Acropolis - to evoke the ancient past and show remnants of a formerly prosperous civilization. In the space between the two travel photographs, a label connected these geographically distant episodes by suggesting that human greed was the reason for these calamitous events, declaring, "ALWAYS BEHIND BLIND GREED FOLLOWED BLIND NEED."

There were optimistic notes amidst the strong overtones of catastrophe, and the panel presented a few examples of humans caring for the earth. Newhall's text read,

YET, WHEREVER PLAIN MEN LOVED THEIR LAND AND LABORED TO KEEP IT RICH, wherever hunters kept forests for their food or pleasure, wherever the hills, the groves and springs were holy... THERE EARTH AND MAN CONTINUED VITAL.

At the end of the panel, alongside this label, Henri Cartier-Bresson's photograph Mohammedan Women Praying, Sunrise, Himalayas is a quiet and uplifting image of India, presenting the possibility for humans to live with an awareness of nature's cycles. However, a label below the photograph left viewers with an inconclusive feeling, as it rapidly advanced from the ancient world to fifteenthcentury Europe, in which England, France, Italy, and Spain experienced severe scarcities in timber and farmland. Newhall's text characterized a barren European continent in which the wilderness had since "VANISHED AND BEEN FORGOTTEN." Her final line of text produced a feeling of suspension, as she described Christopher Columbus sailing away from Europe in search of new land and wealth. 


\section{Panel Three}

There was a leap forward in time between the second and third panels. The narrative continued chronologically with Europeans setting sail on the Mayflower and arriving on the shores of New England in the seventeenth century. Panel Three marked the beginning of TITAE's main exposition, which focussed on America's relationship to the wilderness as well as a uniquely American historical narrative. The first photograph on the panel, Adams's The Atlantic, Clearing Storm, Acadia National Park, is a view of ocean waves illuminated by sunlight after a storm. Newhall introduced a feeling of renewal through the photograph and the accompanying label containing an excerpt from the travelogue of the pilgrim William Bradford. Bradford recounted the settlers' relief at finding land, writing, "Being thus arrived in good harbor and brought safe to land, they fell upon their knees and blessed the God of Heaven." However, the early settlers were unaccustomed to the American wilderness, and Newhall's label also revealed how they perceived it as "HIDEOUS AND DESOLATE ... FULL OF WILD BEASTS AND WILD MEN."

The label subtly implied that indigenous people inhabited the American continent when the settlers arrived. Here, Newhall attempted to distinguish the indigenous peoples' approach to surviving in the wilderness from that of the European settlers, declaring, "HERE MAN, BEAST AND EARTH HAD LEARNED TO LIVE TOGETHER. / BUT, TO WHITE MEN . . . THIS WAS WILDERNESS, A SHOCK, AN OBSTACLE." Newhall selected Adams's Indian Mortar Holes, Yosemite National Park to illustrate the way American Indians lived in harmony with the land. Mortar holes are natural circular depressions in rock caused by indigenous peoples pummeling their food against stone, but without a direct description of this provided in the label, in addition to the abstract quality of the photograph, Mortar Holes more closely represented the way the settlers' perceived the wilderness and the American Indians as a "strange earth."

While Newhall briefly mentioned the American Indians, the exhibition's storyline greatly suppressed their presence. Her narrative continued to describe how the Europeans soon learned how to survive off the land and to "build another Europe" on the new continent. Newhall selected the hand-colored lithograph "Wild Turkey" from James Audubon's Birds of America folio, a uniquely American symbol of the nation's settlement, to mark this important transition. With a strong nationalistic tone, the label above the lithograph confidently asserted, "HERE ANY MAN COULD HEW HIS OWN HOME AND HIS OWN FREEDOM," and from freedom "POURED SUCH WEALTH AND HOPE" among Americans. In this pairing of photograph and text, Newhall characterized the wilderness as a natural right, an economic good, and as a source of inspiration for the American 
people. Continuing to focus on the theme of freedom, Newhall symbolized America's early fight for democracy with Stump in Thunderstorm, Sierra Nevada by Cedric Wright, accompanied by a label containing three short excerpts from three New England settlers, Roger Williams, John Wise, and Jonathan Edwards, who vehemently opposed the Church of England's absolute authority. In relation to the three texts, the dark stump in Wright's photograph gained an anthropomorphic quality, conveying the solitary individual in the fight for freedom. Through a thematic sub-heading, Newhall concluded that nature was direct inspiration for these three Puritans: FROM THE WILDERNESS FLOWED IDEAS THAT TROUBLED EMPIRES: / OF A NEW DEMOCRACY."

Slowing down at the panel's midpoint, Adams's Teton Range from Snake River served as evidence of the aesthetic beauty of the wilderness with its majestic view of the Snake River. However, it was also an image that represented the threatening side of the American wilderness. Its accompanying label described how the wilderness was both a home to the early settlers, and a place where they experienced "fear or exhaustion" in struggling to survive against nature's elements. A separate label nearby signalled the panel's approaching climax: “INEVITABLY, AMERICANS CAME TO DEPEND ON THE WILDERNESS AND TO BELIEVE IT INEXHAUSTIBLE." Newhall then launched into a description of how the growth of settlements became a burden on the land, causing resource scarcities and forcing Americans to move West in search of more land, "again to fell, burn, plough, heedless of warning voices." Newhall selected Arthur Rothstein's photograph Stumps and Rail Fence, Maryland as evidence of the human impact on the land and the man-made structures that intruded on the landscape.

The settlers' activities were ultimately detrimental to their own survival, as Newhall's label described how "corn grew poor in the clearings, the rivers muddy, the game scant in the forests." However, the panel was not purely anthropocentric in its viewpoint, and Newhall equally considered the impact of the settlers' pursuit of economic wealth, through hunting and trapping, on wildlife. Her label read:

Higher along the mountain streams beaver were being killed; down the Pacific Coast the little sea otters cried as the blows rained down ... Down thousands of years, red men had made the prairies and driven across them herds of buffalo, immense as a black tide. But now white hunters, in sheer delirium of the chase, were shooting the buffalo down by hundreds, often to take at most the tongues and leave the carcasses to rot.

In this label, Newhall elevated the American Indians' way of survival, which bore little impact on nature's balance. To further convey the environmentally sustainable practices of the American Indians, beside Rothstein's Stumps and Rail Fence, Maryland, Newhall presented a photograph of an 
American Indian painting on buffalo skin, taken in 1868 by William Henry Jackson, and her label elaborated on the interconnected relationship between the American Indians and the buffalo:

George Catlin, painting the Plains Indians beyond the Missouri in 1832, foresaw that they, along with their buffalo - their food, clothing, shelter, were doomed unless "BY SOME GREAT PROTECTING POLICY OF GOVERNMENT, PRESERVED IN ALL THEIR PRISTINE BEAUTY AND WILDNESS IN A MAGNIFICENT PARK...A NATION'S PARK."

The panel crucially established that the loss of wildlife could lead to the loss of a unique human population, even though Newhall did not explicitly mention the systematic extermination of American Indian peoples. Through photographs and text, Newhall argued that Americans must control their economic activities and live with a greater awareness of nature's balance.

Abandoning the historical narrative of the American Indians, Newhall moved on to describe how Americans, living in increasingly crowded towns and settlements, began to purposefully seek out opportunities to experience "wildness" and travelled to "the White Mountains, the Adirondacks, [and] Maine ... journeying as [they would] to shrines." To convey this important shift in America's relationship with nature, Newhall presented a stereoview of tourists visiting Niagara Falls and arranged it to slightly overlap the corner of a mammoth plate photograph, Yosemite Falls, by Carlton Watkins. Watkins's photograph re-creates the perspective of someone who is walking on the valley floor, and with the trees crowding the frame, he reduced the enormity of the park to an intimate and welcoming section of the valley. Employing this image, Newhall related how America took a major step in preserving its primeval wilderness by founding its first State Park, Yosemite Valley and the Big Trees, in 1864. Newhall concluded the panel with the founding of America's first National Park in 1872 for the "BENEFIT AND ENJOYMENT OF THE PEOPLE," selecting the more abstract and mysterious photograph of nature, Adams's Fountain Geyser Basin, Yellowstone National Park, to represent this milestone event in American conservation history.

Panel Three was deeply rooted in American geography and history, with specific references to its natural landmarks, indigenous peoples, historical figures, and the national fauna. Through eight photographs and a narrative text, the panel expressed how America's early inhabitants found freedom and wealth in the American landscape and their eventual realization, through the land's depletion, that the wilderness is a rare place of inspiration and beauty to be preserved for the future. 


\section{Panel Four}

Despite the creation of a national park, America's Eastern cities were developing rapidly and their residents were in search of more land and natural resources. In Panel Four, Newhall progressed chronologically through American history to detail the period of westward expansion in America, America's industrial exploitation of its resources, and the American leaders that called for a new awareness of the importance of America's natural landscape. At this point in the exhibition, viewers crossed the room from Panel Three to Panel Four, arriving to find an overwhelming display of eighteen photographs and extended labels filled with historical facts about natural resource industries and the people who fought to maintain the nation's balance between development and preservation. Panel Four opened with an untitled survey photograph Rock Point taken in 1863, depicting a group of land surveyors during an expedition into the Mojave Desert region. The photograph evoked the period of exploration in America before the age of mechanized industry and travel, as Newhall's label recounted how the early explorers had "walked three thousand miles to the Pacific. / With long rifle, axe, and plough they had conquered a continent."

With this history of land settlement briefly established, Newhall's text announced the beginning of "a new kind of civilization" in which Americans used "MACHINES WHOSE POWER TO PLOUGH, REAP, SAW, AND KILL INCREASED FAR BEYOND THE EARTH'S POWERS OF RENEWAL." In a roughly vertical sequence, Newhall displayed photographs of various industrialized activities that enabled America to rapidly increase its wealth, including survey photographs of hydraulic gold mining and factory buildings, as well as stereoviews depicting logging and farming. Newhall's label conjured a vivid description of an army of human labourers equipped with machines and their subsequent abuses of the land:

- $\quad$ Miners flung aside pick and pan ... digging for coal or metal, drilling for oil, they left devastation behind.

- Stockmen drove immense herds and flocks ... until it was eaten bare and broken by hooves...

- Market gunners with snares, fumes, fire and guns increasingly automatic, brought down uncounted millions of ducks, geese, curlews ...

- Fishermen trawled and trapped such multitudes of fish...

- Cities and factories turned waste and sewage into the rivers and harbors...

- Farmers ploughed the rich black earth ... planted it without rest or help to the same exhausting money crops. 
However, approaching a main event in the storyline, Newhall portrayed America's strength in overcoming these problems and finding ways to both protect the wilderness and improve the quality of life for its citizens. The American people

- formed societies to enlighten the public ...

- bought with their own funds threatened regions

- set up sanctuaries for birds and beasts in peril of extinction ...

- stormed State legislatures

- called world conferences on world resources.

Her text effectively described the birth of the American conservation movement. In a sermonizing tone, the label proclaimed: "A NEW ETHIC WAS BEING BORN: THAT WE ARE RESPONSIBLE NOW AND TO THE FUTURE FOR WHAT WE DO TO THE EARTH AND TO ALL LIFE UPON IT.” In affirmation of the text, Newhall displayed a photograph of the main actors in these wilderness initiatives_-President Theodore Roosevelt, Gifford Pinchot of the U.S. Forest Service, and John Muir of the Sierra Club, amidst a larger company of men standing in front of an ancient tree in Yosemite National Park.

From here, Newhall delved into the particularities of the American conservation movement, the viewpoints of its main actors, and its milestone events. Newhall presented portraits of the principle figures and created archetypal characters to represent each viewpoint. Beginning with the "Scientist," her label described how the geologist Major John Wesley Powell at the U.S. Geographical and Geological Survey called for improved water management in America's West to mitigate soil erosion. ${ }^{67}$ Newhall selected a portrait of Powell with an American Indian man to accompany her description of Powell's role in the conservation movement. Moving to the bottom of the panel, Newhall provided the perspective of the "President and Forester" illustrated by a photograph of President Theodore Roosevelt and Gifford Pinchot during their Inland Waterways trip, in slight overlap with Adams's photograph National Forest, Mokelumne River area, California. Alongside the paired photographs, Newhall delivered a lengthy text that read much like a history lesson about the founding of the U.S. Forest Service:

PRESIDENT AND FORESTER: From the forestry schools of Europe, GIFFORD PINCHOT brought the concept of PERPETUAL YIELD ... Behind this concept, President Theodore Roosevelt put his fighting strength. In 1905, Pinchot, as Chief Forester, founded the Forest Service.... For the controlled use of all natural resources, Pinchot and others coined the term conservation.

${ }^{67}$ In 1979, Major John Wesley Powell and the U.S. Geographical and Geological Survey conducted an extensive study on water resources and published the "Report on the Lands of the Arid Region of the United States," https://archive.org/details/reportonlandsofa00geog. 
Newhall's labels continued to describe the founding of American institutions including the Bureau of Reclamation, the Sierra Club, the National Park Service, and the Soil Conservation Service, with field portraits of each organization's leader-John Muir “The Naturalist," Stephen Mather “The Businessman," and Hugh Bennett. The result was a crowded panel showing a highly active conservation movement in which numerous characters fought fervently "FOR THE VERY LIFE OF AMERICA." The American nation was portrayed as a positive and determined world leader in the field of conservation; John Muir "dedicated most of his life, writing, talking, [and] leading people to miraculous wild places," while the philanthropist and first director of the National Park Service, Stephen Mather, "devoted the rest of his life" to ensuring that "Americans could reach, live in, enjoy and understand their greatest heritage" through the nation's parks.

The panel closed with Margaret Bourke-White's bleak photograph of eroded farmland, Corn Dust Bowl, but a photograph of a smiling Hugh Bennett of the Soil Conservation Service produced a feeling of optimism. Its label elaborated on the ways in which Bennett taught American farmers to use, save, and protect their soil. The panel ended with a label that proudly affirmed the willpower of the American people, declaring that "today the farmers stay upon their land and fight with science and the law to help them." Thus, although the panel began with a negative sequence of events, Newhall arranged photographs and text to show that America productively responded to its resource scarcities. Striking a nationalistic tone, the panel delivered the history of the American conservation movement and offered inspiring examples of how America was a leader in global conservation efforts.

\section{Panel Five}

Panel Five focussed on water as an essential resource that must be used and conserved in a controlled manner to sustain the American people. The panel opened with a description of the water cycle accompanied by Adams's Sundown, The Pacific, and Grasses in Rain, Alaska showing two different transformations of water through the cycle. Although this introduction to the panel instilled an ecological awareness of nature, the remainder of the panel was less ecocentric in its viewpoint and Newhall delivered a factual presentation about harnessing the benefits of water using dams and reservoirs. 
Newhall presented three photographs of dams in a horizontal sequence along the bottom of the panel-Mono Dam and Reservoir filled with silt, Hetch-Hetchy Reservoir, and Adams's Shasta Dam, California — with a label explaining how America has proactively responded to its citizens' crucial need for water. It read,

ONLY AS A WHOLE, CAN MEN IN UNISON CONTROL WATER.

Today in America our use and need of water, for industry, agriculture, and home is so great that along every major river, the Bureau of Reclamation and other agencies, federal, state, and private, have built systems of dams.

The three dam photographs bore a similar aesthetic, and it was Newhall's labels that transformed them from neutral documentary images into visual arguments. The text presented Hetch-Hetchy dam as an example of poor water management, declaring, "THIS IS HETCH-HETCHY NOW—a desolation. / What we lost here was beyond price - a magnificent and a delight beyond our power to restore." Building up to this conclusion, Newhall's label listed the negative effects of damming natural waterways:

A DAM INTERRUPTS A FORCE MILLIONS OF YEARS OLD ...

- changes the life around it, destroying plants, animals, fish,

- changes the water tables under the lands it irrigates...

- causes the crust of the earth to sink and shift under enormous weights of water...

Draining a country fast eroding, a reservoir may fill up with silt within a generation. Elephant Butte Dam is nearly full; Hoover Dam is filling.

Although the panel did not overtly address the political context of the Hetch-Hetchy dam, the project was strongly opposed by the founder of the Sierra Club John Muir in the early nineteenth century and he lost the campaign to save one of the most unique valleys of the United States. Newhall used the outcome of Hetch-Hetchy to warn against the construction of a dam in Echo Park, which the Sierra Club was then opposing. To represent what America could lose forever if the Echo Park dam was built, Newhall selected Philip Hyde's photograph Steamboat Rock, Dinosaur National Monument showing the monument and its surrounding wilderness. The tone of her panel text became increasingly confrontational as it asked,

WHY SHOULD WE LET A DAM BE BUILT HERE? . .

THE PROPOSED ECHO PARK DAM, UNLESS WE FIGHT TO PREVENT IT, BY PRECEDENT WILL THREATEN OTHER GREAT VALLEYS WITHIN THE NATIONAL PARKS AND MONUMENTS.

Adjacent to Hyde's photograph of Steamboat Rock, Newhall chose Harold Bradley's photograph of severely eroded earth at Lake Meade Reservoir to reinforce the negative effects of damming 
projects, and a nearby label dramatically affirmed that, "A valley once dammed becomes a wasteland."

Despite such a strong indictment, the panel was not one-sided. Newhall also acknowledged that Americans must rely on dams to meet their water needs. Below the photograph of Lake Meade, Newhall presented Adams's photograph Shasta Dam, California as an example of a dam that brings "wealth, power, coolness, food, and drink to millions." Yet, Newhall did not conclude on this message. Instead, she delved much deeper into the logistics of water management with a label that argued for a holistic approach to sustaining water resources.

- [that] the delicate meadows, and the wildlife in them shall not be wantonly disturbed

- that forests on lower slopes shall be cut, grazed and hunted only as science directs to keep them flourishing...

- that around cities and industries air and water shall be kept pure.

Therefore, even though the fifth panel offered Shasta Dam as a shining example of proper water management, Newhall further educated viewers on the complexity of water planning, pedantically stating, "BY THEMSELVES, DAMS CANNOT ANSWER OUR NEEDS FOR WATER." Panel Five closed with a return to nature's inherent beauty. It celebrated the incredible breadth of the Earth's watersheds from the mountains in Adams's The Minarets, Sierra Nevada down to the verdant meadows in Adams's Orchard in Bloom, Santa Clara Valley. Alongside this final image, Newhall's label elevated America's pursuit for clean and plentiful water with a poetic evocation: "WHAT DOES WATER ASK, BUT OUR VISION OF THE IDEAL EARTH?"

\section{Panel Six}

Panel Six brought viewers back near the entrance to the room, and following the exhibition's thematic structure, it highlighted the role of the Soil Conservation Service and the U.S. Forest Service in effectively managing the nation's agricultural and timber resources. Near the beginning of the panel, Newhall embarked on an ambitious program of quantitative facts about the scarcity of the planet's fertile soil resources:

The sea covers four-fifths of the earth. HALF OF DRY LAND IS ROCK TOO STEEP AND HIGH FOR LIFE, or under ice, or too long without rain...

IN THE ENTIRE WORLD, FOR EVERY PERSON THIS MOMENT NOW ALIVE, THERE ARE LESS THAN TWO ACRES OF FERTILE SOIL WHERE CROPS AND FOREST NOW GROW. AND 
SCIENCE SEES ONLY TWO AND A HALF ACRES MORE POSSIBLE THROUGH NEW USES AND TECHNIQUES IN THE FUTURE.

Newhall built a sense of urgency in her label, and employed Bradford Washburn's photograph of a remote, snow covered mountain peak as a visual example of earth's infertile land. However, above Washburn's photograph, in stark contrast to its abstract quality, Adams's Pasture, Medocino County, California is a pastoral view of a farm that conveys the possibility for humans to harness the benefits of fertile land. With Newhall's text enquiring, "HOW SHALL WE LEARN — not to die-BUT TO LIVE?" Washburn's and Adams's photographs represent the two extremes in nature that mankind must learn to mediate.

In answer to the problems of resource distribution and scarcity, Newhall's text described how American farmers persevere with the support of federal agencies such as the Soil Conservation Service. Accompanying the label, Margaret Bourke-White's bold aerial view, Contour Plowing, Colorado, symbolized the nation's large-scale methods of cultivating soil. Newhall also employed this photograph to convey America's leadership in conservation science, as the same label described the ways in which the nation generously reached out to the international community to share its knowledge: "In more than forty other nations, in continents as remote as Africa and India, farmers of all races learn from experts taught in America how to conserve and use their land." To further affirm America's global efforts, Newhall presented a survey photograph of a bund in India, constructed to protect farmland from floods.

Midway through the sixth panel, the narrative turned to a discussion of the national forest reserves, introduced by Adams's Moon and clouds over forest hilltops. Newhall's text outlined a wide range of human uses of forests, conveying their economic value, recreational value, and spiritual value. Her labels offered a range of practical solutions for preserving forests for long term human use, including setting scientific limits to industrial development, private ownership to fund forest protection, and environmental monitoring. To the right of the label, a vertical sequence of three photographs each taken by Adams_-Thimbleberry Leaves and Horsetails, Alaska; Yellow Pines, Sierra Nevada; and Sitka Spruce, Alaska — portrayed the diverse facets of a forest environment, and with the text, it reinforced the need for these solutions: "NO TWO FORESTS ARE ALIKE ... NO MAN YET FULLY UNDERTSANDS THE DYNAMICS OF THE AMERICAN EARTH.”

While Newhall's pairing of photographs and words implied that the wilderness had great ecological value that warranted research and preservation, the subsequent series of labels complicated the 
message by highlighting the economic potential of the forests. In a pragmatic tone, Newhall's text asserted that

TODAY THE NATIONAL FORESTS HOLD

- most of our virgin timber

- one fourth of our commercial timber, which is cut and sold under scientific controls

- $\quad$ one third of our so-called forest lands, burnt-over, cut-over, but necessary for watershed and future forests.

At the bottom of the panel, Adams's Burnt Stump and Grass illustrated the detrimental effect of forest fires with its charred tree trunk. Yet the image was also hopeful, with the possibility for new growth in the young grasses in the foreground. Indeed, Newhall's text revealed solutions to forest management, while elevating the work of the U.S. Forest Service. Her label assured viewers, "Many owners of large tracts cooperate with the Forest Service, or maintain their own foresters and firefighting services ... new laws promise relief to any woodlot owner who practices conservation."

In Panel Six, Newhall characterized the wilderness as a material resource and employed factual evidence alongside landscape and nature studies to argue for conserving fertile land and timber. The panel built a sense of urgency by expressing how essential these resources are to sustaining the American people, and it also presented a series of logical solutions that highlighted the admirable efforts of the Soil Conservation Service and the U.S. Forest Service.

\section{Panel Seven}

Placing economic and nationalistic concerns aside, in the seventh panel of the exhibition Newhall encouraged a purely ecological appreciation of wilderness. As viewers turned the corner of Panel Six to the outer panels on the right side of the room, Panel Seven provided a lyrical description of the processes of life, death, evolution, adaptation, and renewal in nature. The panel opened with a pair of photographs, Cedric Wright's Beach Sand and Edward Weston's Mushroom. With this juxtaposition of two different subjects with similar visual characteristics, Newhall suggested that the two natural elements were innately interrelated. Her label characterized this phenomenon as part of nature's mystery, which was still "beyond our present grasp." Newhall's label echoed Cedric Wright's own philosophy as he once wrote of the wilderness, "A glistening silent world. Imagine all that must be happening there, beyond our knowing." 68 A coral mushroom specimen was mounted

${ }^{68}$ Cedric Wright, Words of the Earth, 30. 
above Weston's photograph, reminding the viewers that the exhibition's message directly related to a world of real living organisms. ${ }^{69}$

Newhall continued to highlight the mysterious powers of nature - its capacity for evolution and adaptation - in the next pairing of Brett Weston's Southern Swamp and his Yuccas, White Sands National Monument. The fluid appearance of the tree trunks in Southern Swamp complement Newhall's label, as she wrote how living organisms first "learned to leave the lapping edge of waters and move upward through climate after climate, continually evolving new forms, fluidly bypassing forms too limited to change." Adjacent to Southern Swamp, Weston's Yuccas represented variation of species within nature, as different desert plants grow and compete with each other. Once again echoing Wright's view of the relationship between man and nature, Newhall's text contended that "without this living pyramid beneath him, man cannot live."70

The panel progressed beyond the concepts of evolution and variation to portray the forces of life and death in nature, and Newhall emphasized the important role of soil in these continuous processes of renewal. Newhall wrote,

THE SOIL IS ALIVE.

It is the fabric of a living chemistry so complex its final mysteries still elude us. One inch of black soil may have taken centuries to make

- centuries of living and dying, by plants and animals moving above in the light.

Edward Weston's photograph Cypress and Stone Crop, Point Lobos gave expression to the text with its dynamic depiction of an entangled forest containing old and new growth. Adjacent to Weston's photograph, a close-up of a delicate insect in Adams's Moth, Interglacial Forest, Glacier Bay National Monument, Alaska supported Newhall's argument that even "the destruction of a single species can shock the entire chain of life."

In the final section of the panel, Newhall characterized the wilderness as a source of profound knowledge with "MYSTERIES AND MIRACLES WE MUST SOLVE” in order to survive. Employing Adams's serene photograph Buck with Antlers, Newhall presented an example of the way man should humbly approach nature, "light and silent as any other, to look, to listen, and leave no more trace of his passing than a deer." Newhall also described the power of instinct between animals as

\footnotetext{
${ }^{69}$ Hammond falsely identified the object as a nautilus shell rather than a coral mushroom, which is the name of a common type of mushroom that grows on decaying vegetation. Divine Performance, 114.

70 Wright wrote, "One is aware, lying under trees, of the roots and directions of one's whole being." Words of the Earth, 40.
} 
her next label referred to the migratory patterns of animals, following "paths older than man," accompanied by William Garnett's photograph Flight of Pelicans. ${ }^{71}$ With Newhall's text declaring that "THE WILDERNESS HOLDS FOR US MORE ANSWERS THAN WE YET KNOW HOW TO ASK," the final photograph by Adams, Bird's Nest, served as a visual metaphor for the way nature holds precious answers about its life cycles, which humans must discover. In Panel Seven, Newhall established nature as a complicated and versatile living system with the innate ability to govern its own renewal. With a heightened ecological perspective, Newhall informed viewers that the chain of life can easily be disrupted through human use, and encouraged humans to approach nature with an enquiring mind to learn its inherent balance.

\section{Panel Eight}

“OF ALL RESOURCES, THE MOST CRUCIAL IS MAN'S SPIRIT,” the next panel pronounced. Where in Panel Seven the wilderness seemed to be the most essential part of the natural order, Panel Eight placed man at the center of the universe and expressed the value of nature in terms of its spiritual benefit to humans. In a strong visual argument for turning wilderness areas into National Parks, seven photographs by Adams depicted the impressive landscapes of the national parks. A small cluster of rock minerals displayed in a case began the panel, and directly below this object, Adams's photograph Mount McKinley, Dawn, Mt. McKinley National Park, Alaska represented the "AWE, WONDER, AND DELIGHT OUR FATHERS FELT ON FIRST BEHOLDING THE GREATEST SPLENDORS OF THE AMERICAN EARTH." Presented in bold typeface, Newhall's label firmly linked the National Parks to America's birth as a nation. Gaining meaning from this theme, each subsequent photograph on the panel became a highly emotional appeal related to the sense of discovery and opportunity felt during America's frontier days of primeval wilderness.

The enormous geologic formations in Grand Canyon enabled man "to know immensity" and to witness the forces that shaped the continent billions of years ago. Papoose Room, Carlsbad Caverns placed viewers beneath the surface of the earth to hear the sound of "jewelled water," while the explosion of water in Old Faithful Geyser, Yellowstone National Park served as evidence of the powerful natural forces hidden within the earth. In the final photograph, Sequoia Gigantea,

\footnotetext{
${ }^{71}$ In the exhibition, Garnett's photograph was titled Flight of Pelicans. However, the correct title is Snow Geese over Buena Vista Lake. Adams and Newhall, This Is the American Earth (San Francisco: Sierra Club, 1992), 63.
} 
Mariposa Grove, Yosemite National Park, California, Adams photographed the trunks of tall forest trees, excluding their leafy canopies, to recreate the view from the forest floor. To accompany the photograph, Newhall selected a line of verse by the poet Walt Whitman, who wrote, "WHY ARE THERE TREES I NEVER WALK UNDER BUT LARGE AND MELODIOUS THOUGHTS DESCEND UPON ME?" Her pairing of photographs and text suggested that the American wilderness can inspire human creativity. Newhall's sequence of photographs in Panel Eight, depicting the variety of the American landscape from its deep canyons to snowy precipices, illustrated how America's national parks are a source of inspiration beyond both human imagination and scale.

\section{Panel Nine}

In Panel Nine, Newhall contended that the National Monuments, which preserved the most important sites in American history, are essential to sustaining the freedom of the American people. ${ }^{72}$ Newhall's labels carried a heavy patriotic sentiment as she described specific events in America's struggle for independence. Newhall selected photographs depicting American places that were

\section{hallowed by history}

- the houses where great men lived and died,

- the halls where freedom spoke and acted,

- the battlefields.

Newhall presented a photograph of the house of the American politician John Adams, who had fought for America's independence. She also selected Alexander Gardner's photograph Home Of a Rebel Sharpshooter taken just after the Battle at Gettysburg during the American Civil War, accompanied by a label that reproduced Abraham Lincoln's famous Gettysburg Address at the founding of a national cemetery in 1863.

Newhall briefly acknowledged the role of the indigenous peoples who inhabited and shaped the land that became the American continent before the European settlers arrived. Adams's photograph Mission from Graveyard, Tumacacori, New Mexico with its line of makeshift crosses against an adobe chapel, juxtaposed with the cliff dwellings of indigenous tribes in his White House

\footnotetext{
72 The paper copy of text for Panel Eleven does not provide photograph titles or arrangement. Undated exhibition text, "Master/File Copy," Bancroft Library.
} 
Ruin, Canyon de Chelly National Monument, Arizona served as evidence of "what men of all faiths, nations and races have given America."73

Within this narrative of freedom and unity, Newhall also expressed that America's landscape has the ability to inspire human creativity. Beneath two adjacent photographs by Adams of Yosemite Valley, a line of verse by Walt Whitman characterized nature as the "origin of all poems."

Reinforcing her argument, Newhall selected Barbara Morgan's photograph Girl With Recorder to accompany a label stating that if man lost all capacities for knowledge and artistic creation, his relationship to the wilderness would ensure that he "could again hear singing in himself and rebuild anew the habitations of his thought." In Panel Nine, Newhall injected America's past with a sense of heroism and idealism. She constructed a particular version of American history, in which all its citizens were recognized for their contributions to the nation's fight for democracy. To this end, Newhall argued that natural lands, preserved in the National Parks and Monuments, were important sites of human inspiration, freedom, and individuality.

\section{Panels Ten, Eleven, and Twelve}

These three panels are here discussed together because they were not designed by Adams and Newhall, and their content vastly differed from the other panels in the exhibition. Designed by the Sierra Club members Frann Spencer Reynolds and Richard Reynolds, Panels Ten and Eleven were painted with simple pictorial representations of forests, mountains, and fauna surrounding large blocks of text. The two panels were intended to be read as a pair and presented two contrasting approaches to managing forests, with Panel Ten describing the earliest forestry methods developed by the American Indians, and Panel Eleven describing the newer forestry methods of the European settlers. They were positioned along the back wall of the lodge on either side of the grand fireplace. In the exhibition leaflet, Panel Ten referred to as "The Redman's Sierra Nevada."74 From the installation photographs, one can ascertain that the four texts on Panel Ten were titled: Introduction, His Fire Shaped His Forest, Red Man's Stream Sides Fostered Life, and Sunlight, Space, and Greenery. ${ }^{75}$ Primarily employing text, the panel conveyed how American Indians were able to

\footnotetext{
${ }^{73}$ The inclusive message and tone of idealism closely match the theme of Newhall's exhibition $A$ Nation of Nations, which was produced two years later in 1957.

${ }^{74}$ Undated leaflet, "Sequence of the Exhibit," folder: "This Is the American Earth at LeConte Lodge, 1954," AAA at CCP.

75 Undated loose photographs, box 242, folder 3, GRI.
} 
maintain bountiful forests and streams through a variety of practices including controlled burnings. Panel Eleven was referred to in the leaflet as "The Whiteman's Sierra Nevada."76 The panel described how white settlers changed the composition of the forest and the shape of its waterways through four texts: Suppressing Fire Has Shaped His Forest, Whiteman's Stream Sides, Water Rocks and Roots, Concentration Plagues Us Wherever We Go, and Conclusion. ${ }^{77}$ The panel text strongly favored the American Indians' practices, which had less of an impact on nature's balance.

Having crossed the room along the back wall, viewers returned to the left side of the room at Panel Twelve, the third panel in the exhibition that was not created by Adams and Newhall. Designed by Ted Spencer, the panel featured a painted interpretation of a map of Yosemite Valley by the artist Samuel Provenzano, overlaid by four long texts and three photographs by Adams-Anne in Meadow, Yosemite National Park; Cliffs and River, Autumn, Yosemite National Park; and Yosemite Valley, Summer. Since no manuscript for the text to Panel Twelve has been located, the precise theme and argument of the panel cannot be clearly determined. From the installation photograph, it is possible to discern that the introductory text, positioned above Anne in Meadow, read,

For a fleeting moment our imagination transforms us into a little girl in a mountain meadow awed and enlightened by the beauty of nature around her.

The emotion portrayed by the little girl is our own emotion in beholding in reality the river meadow and the sheer granite wall of Yosemite Valley.

Like Panel Eight on the National Parks, Spencer began with an emotional appeal for the importance of the wilderness. Yet, from correspondence between Spencer and Newhall preserved at the Center for Creative Photography, it seems that the remainder of the text was a more factual treatment of the topic in the form of a short essay. An early undated outline for what Spencer called the "Planning Panel" is useful for understanding its broad subject matter. Spencer divided the subject matter of the panel into four sections. He proposed that section one produce "a short review of the formation of the Valley" describing how the valley has changed within the last one hundred years. Section two would provide a definition of conservation, distinguishing it from other "cult" definitions. Section three would provide data to support the predicted rise in California's population by 1970, and lastly, section four would convey how Yosemite could be designed "for flow and movement of people" while preserving the most important zones. ${ }^{78}$ Seeing the landscape

\footnotetext{
76 Undated leaflet, "Sequence of the Exhibit," folder: “This Is the American Earth at LeConte Lodge, 1954," AAA at CCP.

77 Undated loose photographs, box 242, folder 3, Nancy Newhall Papers, GRI.

78 Undated outline for Panel Twelve, box 10, folder "This Is the American Earth (Exhibit)," NN at CCP.
} 
as an architectural planner, Spencer proposed a way for Yosemite to be better preserved and accessed through a consideration of geography, design, visitor accessibility, and land planning.

\section{Panel Thirteen}

In Panel Thirteen, Newhall encouraged viewers to step into nature to experience its beauty and wonders. Following the line of outer panels on the left side of the room, viewers arrived at eight photographs by Adams, Eliot Porter, and Bradford Washburn, as well as another butterfly specimen. To open the panel, Newhall employed the same writing style as Panel One, enquiring, "WHO IS NOT GRATEFUL FOR A ROAD THAT LEADS TO WONDER?" And the text immediately answered its own question when it replied, "to the primal wonders no road can ever lead; they are not so won." Above the text, Adams's photograph Trees, Illilouette Ridge, Yosemite National Park depicts two large tree trunks that appear to block a path to the wilderness beyond them. Newhall's text suddenly changed to a more intimate voice, addressing the viewer directly with an informal "you," and recounting the rewards that await humans when they enter nature with only a few belongings and close companions. The label read, "You shall see mountains rise in the transparent shadow before dawn. / You shall see—and feel—first light." Nearby, Adams's Mount Whitney, Dawn, Sequoia National Park, directly illustrated Newhall's text with an image of a mountain in silhouette at dawn.

Moving towards the bottom of the panel, Newhall directed viewers into a purely emotional understanding of wilderness, displaying two abstract nature studies by Adams, Frozen Lake and Cliffs, Sierra Nevada and Pool, Leaves and Sun Reflections, Sierra Nevada, without an accompanying text. Indeed, in 1984, John Szarkowski noted that Frozen Lake and Cliffs had a "deathly elegance," and was "not a landscape for picnics, or for nature appreciation, but for the testing of souls."79 However, the exhibition soon transitioned back into more picturesque views. In presenting the next photograph, Adams's Cedars, Sierra Nevada, Newhall suggested that the wilderness was a nurturing place for the human body and mind, as her label read, "You shall enter the living shelter of a forest. / You shall walk where only the wind has walked before."

Moving back to the top of the panel at its midpoint, Newhall embarked on a highly spiritual entreaty for preserving the wilderness. Adams's photograph Clouds, Sierra Nevada formed the visual climax

79 John Szarkowski, “Kaweah Gap and Its Variants," in Untitled 37, Ansel Adams: 1902-1984 (Carmel: The Friends of Photography, 1984), 14. 
of the panel and Newhall's text contributed a divine quality to the landscape, declaring, "You shall live lifted up in light; you shall move among clouds. / You shall see storms arise, and drenched and deafened, shall exult in them." The tone is biblical, in its effort to persuade the viewer of the spiritual value of nature. Following this theme, to the right of Clouds, Sierra Nevada, Eliot Porter's photograph of a bird evoked the spiritual imagery of doves. Unlike Panel Seven, in which Newhall described birds as part of a system of ecological processes, Porter's illuminated tern defies any earthbound associations.

At the panel's close, Newhall intensified the religious mood, proclaiming, "You shall top a [mountain] rise and behold creation. / You shall see visions further than poet or prophet could ever utter." Alongside this label, the photograph Mt. Saint Elias, Alaska by Bradford Washburn, with its blinding white mountains, is transformed into an image of heaven itself and stands in stark contrast to the dark tones in the previous seven photographs. Where photographs and words interacted with each other in the previous panels, text is particularly essential to communicating the message of Panel Thirteen. Newhall's labels invited viewers to enter into each photographic scene as though standing on the edge of the wilderness. Nearing the exhibition's finale, Newhall completely removed factual content to express a spiritually gratifying experience that is available to mankind in nature.

\section{Panel Fourteen}

With elevated prose and a powerful tone of optimism, Panel Fourteen encouraged mankind to open his eyes and become enlightened to the possibility of a renewed relationship with the natural world. Newhall's text seemed to rejoice in the wilderness, stating, "A WORLD PRIMAL AGAIN! VISTAS OF GLORY, INCESSANT AND BRANCHING." Borrowing this line from Walt Whitman's poem Leaves of Grass, Newhall called for a return to the wilderness of America's frontier days, when the land was still largely undeveloped. She selected Adams's From Moro Rock, Sequoia National Park to represent the sense of opportunity and expanse of the American landscape. Then, Newhall fashioned the conservation movement into a battle, in which the whole of humanity, "throughout America and the world," is united in preserving this wilderness for the future.

Next to Moro Rock, Newhall conveyed man's position in the natural order as "halfway between the atom and the universe" with a photograph of the Pleiades constellation positioned nearby Barbara 
Morgan's photograph Head of Lloyd. In the remainder of the panel, Newhall displayed various nature studies and landscape photographs that reinforced the feelings of hope and renewal in her text. The panel ended with Adams's Heaven's Peak, Glacier National Park, an image of sunrise breaking over a snowy mountain peak. The base of the mountain lies in darkness, awaiting warmth and illumination. Newhall's label related this photograph to the concept of a new existence for mankind:

Morning brings back the heroic ages.

The morning wind forever blows, the poem of creation is uninterrupted.

Olympus is but the outside of the earth everywhere. 80

Only that day dawns to which we are awake.

There is more day to dawn.

The sun is but a morning star. 81

Here, Newhall quoted from Thoreau's Walden, framing man's pursuit of enlightenment as a heroic enterprise. Related to the theme of the exhibition, it promised that Americans would be filled with the heroism of their nation's past, once they gained a higher understanding of the wilderness. In Panel Fourteen, Newhall departed from any material considerations of the natural world, and placed trust in man's ability to develop a new relationship with nature and to preserve the primal beauty of the American wilderness.

\subsection{PUBLIC RECEPTION}

This Is the American Earth's opening at the California Academy of Sciences failed to attract the attention of local or national media. It appears that only one Bay Area newspaper, The San Francisco Chronicle, reviewed the exhibition in a column by the art and music critic Alfred Frankenstein. This review was reprinted in Aperture magazine in 1955, yet the columnist gave no indication of which exhibition venue he attended — the California Academy of Sciences or the LeConte Lodge — and without a date provided in the reprint it remains unclear. In the review, Frankenstein evaluated TITAE's function over its artistic merit, writing little about the photographs or sequencing of the exhibition. Instead, he established TITAE as a "propaganda show," suggesting that it might "never have been organized at all if it were not for the Echo Park controversy." ${ }^{2}$

${ }^{80}$ Henry David Thoreau, Walden, Volume I (Boston; New York: Houghton Mifflin, 1897), 140.

${ }^{81}$ Henry David Thoreau, Walden, Volume II (Boston; New York: Houghton Mifflin, 1892), 514.

${ }^{82}$ Alfred Frankenstein, review of This Is the American Earth exhibition, by Ansel Adams and Nancy Newhall, The San Francisco Chronicle, n.d. Reprinted in Aperture 3, no. 2 (1955): 33. 
The exhibition's subsequent venue in the summer of 1955 at LeConte Lodge furnished it with a large potential audience as approximately one million tourists filtered through Yosemite National Park. ${ }^{83}$ However, the public's response seems to have been lukewarm. At the end of the summer, the custodian of the lodge briefly reported that visitors did not spend time reading the panel text, though they did comment on the "beautiful pictures." ${ }^{84}$ It is likely that the public, whose primary purpose was to experience the sights of Yosemite National Park, was not prepared to spend time looking at visual representations of what awaited them outdoors, or to wade through an elaborate text. This response varied slightly on the exhibition's tour, based on the type of venue in which it was shown. In the academic setting of the Stanford University Library, which is the first known touring venue, TITAE was well received for its educational content and was proactively shown to audiences of children. The librarian wrote Adams a letter of gratitude to say that "never has an exhibition before engendered so much satisfaction and wholesome pride amid the faculty and students." 85 During the exhibition's tour to the Slater Memorial Museum in Connecticut in 1958, as part of the Smithsonian's itinerary, it was similarly viewed as educational. The Museum Teacher wrote a letter of thanks to the Smithsonian and reported that the exhibition was being presented in conjunction with a series of films about conservation in their own region. ${ }^{86}$

Near the end of 1955, Modern Photography published an unsigned article on TITAE, in which the exhibition was deemed "one of the most beautiful and remarkable photographic exhibitions ever put together." Seven of the exhibition's photographs were reproduced—one by Cedric Wright, one by Edward Weston, and five by Adams. ${ }^{87}$ No author was identified nor was the venue at which the author viewed the exhibition, suggesting that the piece was not an actual review. It is likely that Adams and Newhall supplied the magazine with the text. Some telling signs are in the article's language. Where it described the exhibition's cased objects as "sculptural relief" and "bits of color" the voice matches Newhall who wrote a similar idea in her letter to Adams in 1954.88 The editors of

831954 marked the first year that Yosemite National Park had 1 million visitors. National Park Service, "Park Statistics," accessed 16 July 2014, http://www.nps.gov/yose/naturescience/parkstatistics.htm.

84 Sierra Club Board of Directors, "American Earth Exhibit," November 1955, Sierra Club Board of Directors Meeting Minutes 1954-1955, Bancroft Library, http://oac.cdlib.org/ark:/28722/bk000786x9c/ ?order $=158$.

85 W.B. Ready to Eldridge T. Spencer, 9 November 1955, AAA at CCP.

${ }^{86}$ The Slater Memorial Museum at the Norwich Free Academy of Connecticut to Annemarie Henle Pope, 5 February 1958, NN at CCP.

87 Unidentified author, "Close-Up On Nature," Modern Photography, November 1955, 86-89; 124. ${ }^{88} \mathrm{NN}$ to AA, 3 August 1954, AAA at CCP. 
Modern Photography would have been receptive to publishing an article on This Is the American Earth, as they had published many articles by Beaumont Newhall in the past. ${ }^{89}$ Likewise, the Associate Editor Cora Wright, and her husband George Wright, had been contributors to Aperture - the brainchild of Adams, the Newhalls, and Minor White as well as a close-knit group of their contemporaries working in the field. ${ }^{90}$

That is to say, with their panel exhibition going to venues where photography exhibitions would ordinarily not be reviewed — in Yosemite Park and a university library — Adams and Newhall had to make use of their connections in the photography world to find TITAE a bit of spotlight. It was especially difficult because the blockbuster show at MoMA, Steichen's The Family of Man, had been the center of the relevant media's attention for the entire year, and was being hailed as a landmark exhibition in photography. One can imagine that Newhall and Adams were feeling quite defeated. It would be no exaggeration to say that Steichen was their arch nemesis after all that had transpired at MoMA years earlier. ${ }^{91}$ Later in life, Newhall wrote to a young writer at Afterimage:

I have the greatest difficulty in overcoming my prejudice-even hate-of Steichen, even now he is finally dead. I do not deny his power and courage, but I cannot forgive his attempt to kill photography as an art and turn it wholly into communication, with himself as the great creator of exhibitions in the center of the stage. ${ }^{92}$

Moreover, having the chance to mount his photography exhibition at one of the only art museums exhibiting photography at the time, Steichen had received the huge audiences and wide acclaim that Adams and Newhall surely wanted for their own exhibitions.

With The Family of Man consuming all media outlets, Adams and Newhall turned to their own invention, Aperture, to ensure that TITAE would be remembered in the history of photography. They placed TITAE in an issue of Aperture that also reviewed what they saw as the three most significant photography exhibitions of the century. The issue began with Stieglitz's 1910 exhibition 1971).

${ }^{89}$ Robert Sobieszek and Patricia A. Slahucka, Beaumont Newhall (Rochester: George Eastman House,

${ }^{90}$ Aperture was conceived during a photography conference in October 1951 at the Aspen Institute for Humanistic Studies in Aspen, Colorado. The other panel participants included Dorothea Lange, Berenice Abbott, Herbert Bayer, Frederick Sommer, and others. Peter C. Bunnell, Maria B. Pellerano, and Joseph B. Rauch, Minor White: The Eye That Shapes (Princeton: The Art Museum, Princeton University, 1989 ), 7. Published in conjunction with the exhibition of the same name, which opened at the Museum of Modern Art in New York.

91 O’Toole, "No Democracy in Quality," 288-317.

92 NN to Ellen Manchester, 12 June 1973, NN at CCP. 
of the Photo-Secession at the Albright-Knox Gallery in Buffalo, New York. Next, it recounted the 1929 exhibition Film und Foto (FiFo) in Stuttgart Germany, and strangely skipping over Beaumont Newhall's Photography 1839-1937, it came to Steichen's 1955 exhibition The Family of Man exhibition. Lastly, it reviewed the 1955 exhibition This Is the American Earth. ${ }^{93}$

The editors composed a particularly lengthy review section on The Family of Man titled "The Controversial Family of Man," which included twenty pages of reprinted reviews, opinion pieces, and articles. It was here that the editors established the complex theoretical groundwork to later prove how TITAE was a landmark exhibition firmly in the tradition of Stieglitz and exhibitions of art photography, but also on par with the contemporary treatment of photographs in The Family of Man. In particular, Barbara Morgan's and Dorothy Norman's articles provided the resolution between Stieglitz and Steichen that would inform Aperture's evaluation of TITAE.

The final review section on This Is the American Earth included a reprint of Newhall's exhibition text and two reviews. Minor White, delivering the last review signed with his alias "Sam Tang Wu" would apply Norman's and Morgan's conclusions to TITAE as he asserted in his mock Chinese, "In Earth show intention of photographer with his photograph is respected" in the tradition of Stieglitz, and that "this year will be remembered as the year of the Theme Shows" in the tradition of Steichen. Through Aperture, Adams and Newhall made a deliberate attempt to historicize their conservation exhibition. Although they disliked Steichen's exhibition, they were conscious of the fact that TITAE shared many qualities with The Family of Man, and they would use these points of resemblance to prove that This Is the American Earth deserved an equal amount of recognition as Steichen's blockbuster.

\subsection{THE USIA}

From 1957 to 1959, the exhibition TITAE was circulated worldwide by the USIA. The details of the tour seem to have gone largely undocumented and the primary research has yet to produce a complete list of the exhibition's touring venues, public response, and attendance record. However, through the correspondence between Adams, Newhall, and the USIA, it is possible to sketch a partial account of the exhibition's international reach. In the context of the Sierra Club, the TITAE exhibition was an affirmation of America's unique geography and people, and a stimulating

\footnotetext{
${ }_{93}$ Aperture 3, no. 2 (1955): 1-34.
} 
argument for preserving natural resources. The USIA would have certainly been attracted to the sense of idealism across the panels, with the exhibition's emphasis on freedom, democracy, and innovation. It is beyond the scope of this thesis to investigate exactly how TITAE might have furthered foreign relations between America and each of the countries on TITAE's tour. Yet, as an important cultural context of the exhibition, this thesis will present the essential facts regarding its tour under the USIA.

Near the end of 1955, Newhall promoted the TITAE exhibition to the USIA. ${ }^{94}$ Although her exact purpose in doing so was not explicitly stated, one can imagine that both she and Adams wished to spread the gospel of conservation and photography to all corners of the world, and that they had been motivated by the popular success of The Family of Man exhibition which had been touring under the USIA since 1955.95 The tour would also give Adams's photography important international exposure that would lead to print sales and requests to publish in magazines. On Newhall's first attempt at promoting the exhibition TITAE, the agency rejected it on the grounds that the "subject matter does not contain sufficient propaganda value."96 Unfortunately, at least in this letter, the USIA never revealed its criteria for evaluating potential propaganda material. However, in less than a year's time, the USIA had changed its opinion of the show. After finding it listed in the Smithsonian's travelling exhibitions catalogue, which they frequently referred to for new exhibitions, they ordered four copies of TITAE. ${ }^{97}$ Following normal procedures, the Smithsonian Institution arranged the contract with the USIA and charged 5\% of the total cost of the exhibition for "handling the contract, dispersal of funds, and general supervision of the work."98

For construction of the four copies of the exhibition, the USIA was charged $\$ 20,000$, which included $\$ 8,000$ for production of the photographs alone. ${ }^{99}$ Within a few months of establishing the contract, Adams began printing six sets of photographs, with one reserved for emergency replacements and

\footnotetext{
${ }^{94}$ Yoichi R. Okamoto, Deputy Chief Visual Materials Branch Press Service to NN, 22 November 1955, AAA at CCP.

${ }_{95}$ The Family of Man had toured to thirty-eight countries over a period of seven years, ending its tour in 1962. Eric Sandeen, Picturing An Exhibition: The Family of Man and 1950s America (Albuquerque: University of New Mexico Press, 1995), 95.

${ }_{96}$ Yoichi R. Okamoto, Deputy Chief Visual Materials Branch Press Service to NN, 22 November 1955, $\mathrm{AAA}$ at $\mathrm{CCP}$.

${ }^{97}$ Annemarie Henle Pope to Thomas Beggs, 12 July 1956, Smithsonian Institution Archives. By 1961, the Smithsonian Institution had assembled thirty-six exhibitions for circulation under the USIA. "Art on the Road" Radcliffe Quarterly, May 1961, AAA at CCP.

${ }^{98}$ Annemarie Henle Pope to Thomas Beggs, "New USIA Contract," 12 July 1956, Smithsonian Institution Archives.

${ }^{99}$ Ibid.
} 
one for publicity purposes. ${ }^{100}$ Frann Spencer Reynolds made eight copies of the painted panels and the artist Samuel Provenzano made four copies of the illustrated panel designed by Ted Spencer.101 The USIA's four copies were identical to the original version of the exhibition with the exception of the cased objects and the original photomechanical reproduction. ${ }^{102}$

It appears that Newhall might have also been required to modify some of the text to suit an international audience, since Michael Barjansky, the Chief of the Development Branch of the Exhibits Division at the USIA explained to Newhall that "many of the conservation matters presented in this exhibit involve local issues of interest primarily to people in the United States. Our overseas audience will be interested mainly in the overall story, and our experience has been that they will not read lengthy text." 103 Newhall responded with the recommendation to completely remove the lengthier texts on the three painted panels, and for specific venues, the USIA took the liberty of omitting any lines of text that might have stirred up controversy or offense. ${ }^{104}$ The panels were outfitted with aluminum channels to accommodate interchangeable labels carrying the translated text. 105 At the end of September 1957, the exhibition was shown at Photokina in Cologne, and from the Smithsonian records, this appears to have been the first venue of the exhibition's international tour. ${ }^{106}$ From there, the exhibition travelled to Baghdad, Belgrade, and Tokyo, the latter of which asked permission to produce a small book on the exhibition. ${ }^{107}$

Newhall was proactive about proposing book and exhibition projects to the USIA. In September 1956, in a letter discussing the exhibition translations, Newhall also asked the USIA if they would be interested in the book This Is the American Earth for their program, although it had yet to be produced. ${ }^{108} \mathrm{~A}$ few months later, Newhall received a response from the USIA, filtered through

${ }^{100}$ Five Associates to Smithsonian Institution, 8 October 1956, Smithsonian Institution Archives.

101 Ibid.

102 Annemarie Henle Pope to NN, 15 August, 1956, Nancy Newhall Papers, box 242, folder 3, GRI.

103 Michael Barjansky to NN, 16 July 1956, NN at CCP.

104 Michael Barkansky at the USIA Chief Development Branch Exhibits Division to NN, 1 August 1956, Nancy Newhall Papers, box 242, folder 3, GRI. A manuscript of the exhibition text showing the omissions has not been located.

${ }^{105}$ AA to Brower and Dr. Miller at the California Academy of Sciences, 1 July 1956, Sierra Club Members Papers, carton 21, folder 42, Bancroft Library.

${ }^{106}$ Annemarie Henle Pope to Thomas Beggs, "New USIA Contract," 12 July 1956, Smithsonian Institution Archives.

107 Joseph Nebesky, Exhibits Division Information Service Center to AA, 29 August 1957, AAA at CCP. Eugene A. Schnell, Exhibits Division Information Service Center to Annemarie Henle Pope, 12 July 1957, AAA at CCP.

${ }^{108}$ Newhall suggested the USIA buy 30,000 copies at $\$ 1.50$ wholesale price. NN to Michael Barjansky 22 September 1956, AAA at CCP. 
Adams, saying that the cost of the TITAE book exceeded their budget, but that they were interested in a more reasonably priced publication with the same subject matter, as "our need for this type of book continues and our desire to use such books as yours in our program is strong."109

The USIA, known abroad as the United States Information Service (USIS), adopted the former propaganda efforts of the Office of War Information Overseas Branch (OWI), which operated during WWII. The OWI was responsible for disseminating an ideal American image of "industrial and military strength, technological progress, ethnic and racial harmony, and cultural freedom."110 Similarly, the main goal of the USIA was to inform foreign countries about American culture and policy. It achieved its objective by distributing real and positive examples of American popular culture through seven media outlets including radio, television, movies, illustrated press, books, exhibitions, and the arts. ${ }^{111}$ Indeed, the USIA's promotional material for TITAE plainly stated the exhibition's original purpose in America:

The exhibition, sponsored in the United States by civilian societies interested in science and conservation, was originally created to inform American citizens, through the images and history of their own country, about one of the basic and crucial problems faced by the world today. 112

The statement expressed the belief that the exhibition was about uniquely American themes and, at the same time, America's engagement with the world. Visually, the exhibition would be easily understandable to a foreign audience as it displayed an array of beautifully printed photographs of pristine landscapes and nature studies, and a text that highlighted America as a leader in conservation science, a technological innovator, and a country that nurtured individual freedoms.

${ }^{109}$ Joseph F. Privitera, Chief Book Development Branch Information Center Service at the USIA to AA, 15 November 1956, file "Ansel Adams, 1956," Book Development Files 1944-1968, Records of the USIA, Record Group 306, National Archives and Records Administration.

110 Nick Natanson, "Old Frontiers, New Frontiers: Reassessing USIA and State Department Photography of the Cold War Era," accessed May 27, 2014, http://www.archives.gov/research /foreignpolicy/cold-war/conference/natanson.html.

111 Transcribed speech by Edward R. Murrow before the National Press Club in D.C. Release No. 24, “Who Speaks for America," 24 May 1961, folder “U.S. Information Agency (USIA) 1960 and 1961: JanuaryJune, Papers of John F. Kennedy, Presidential Papers, President's Office Files, Series 7, http://www.jfklibrary. org/Asset-Viewer/Archives/JFKPOF-091-001.aspx.

112 NN to Lawton Kennedy (exhibition text printer), 27 August 1956, AAA at CCP. 


\section{CHAPTER THREE}

\section{THE BOOK THIS IS THE AMERICAN EARTH}

Expanding on the exhibition's message and expression, Adams and Newhall developed the book This Is the American Earth, published by the Sierra Club, which would continue to bring fine art photography and conservation to a widespread audience. Two years after the initial opening of the exhibition This Is the American Earth, Newhall and Adams embarked on their production of the book, researching and selecting photographs once again to polish their grand statement on conservation. The first part of this chapter will describe important events that set the stage for a conservation-themed book of photography. Following this, the chapter will necessarily discuss the major influences on Adams's and Newhall's aesthetic decisions for the book-design, layout, and image selection — which found much inspiration in contemporaneous exhibitions and books of photography. Like the exhibition This Is the American Earth, the book was a confluence of changing perspectives within the conservation movement, and the third section of the chapter will explore the role of the Sierra Club in shaping the content of the book. In particular, the Sierra Club Executive Director, David Brower, was a leading proponent of the book and a strong influence in Newhall's process of transforming exhibition panels into book pages. The fourth section of this chapter will analyze the book's images and text, highlighting ways in which it borrowed or diverged from the exhibition, and will be followed by details of the public response to the book, which had considerably better success than its precursory exhibition.

\subsection{TRANSFORMATION: FROM EXHIBITION TO BOOK}

Adams's and Newhall's idea to produce a conservation-themed book developed alongside their process of formulating the exhibition This Is the American Earth. In May 1954, while drafting the exhibition, Newhall felt that the panel format did not effectively convey the meaning and emotion of her text. She wrote to Adams that "when one of us reads aloud, or when the continuous text is in the audience's hand, it produces more effect."1 Minor White, who was working as an assistant curator at George Eastman House, and was also an editor of the museum's journal Image, had a chance to review this material with Newhall and offer his opinion. As Newhall recounted to Adams, White expressed enthusiasm over her initial sketches but also felt that "the full significance of text and

\footnotetext{
${ }^{1} \mathrm{NN}$ to AA, 6 June 1954, AAA at CCP.
} 
image got lost in the presentation (the paste-up)," suggesting that film or television would be better suited to her design. ${ }^{2}$ Newhall certainly had a deep appreciation for popular media, yet her primary mode of creative expression was the book form. ${ }^{3}$ In that year alone, Newhall had been working on several photographically-illustrated books with Adams, including The Pageant of History and the Panorama of Today in Northern California for the American Trust Company in San Francisco, Death Valley, and Mission San Xavier del Bac. ${ }^{4}$ By June 1954, Newhall's sketch for the panels had come to closely resemble the book form and she continued to work in the structure of a book as she developed the content of the exhibition over the next two months. ${ }^{5}$

It is likely that throughout the process of creating the exhibition, Newhall was drawing upon the concept for a book that she and Adams had first discussed in 1952, about the "discovery and development of America in terms of English, Dutch, French, Spanish, Scandinavian and Russian exploration and development, the cultures they brought with them ... and use of the land in reference to the great conservation problems of our time."6 The subject matter reflected Newhall's ongoing interest in America's early inhabitants, which she likely gained through her introduction to the writings of Mary Austin by Ansel and Virginia Adams, and further developed in her articles for Arizona Highways magazine in the early 1950s. The book, which Adams and Newhall had preliminarily titled Always the Far Horizon, never came to fruition. Yet, the similarity of its conceived content to the exhibition TITAE provides a window into understanding how Newhall initially imagined and shaped the exhibition as book pages instead of panels. By the time Adams was scheduled to present the outline of the exhibition TITAE to the Sierra Club directors, Newhall was still struggling to condense what she called "the book" into exhibition panels.7 She asked

\footnotetext{
2 NN to AA, 6 June 1954, AAA at CCP.

3 Writing in retrospect, Newhall identified her 1950 photobook with Paul Strand, Time in New England, along with Adams's My Camera in the National Parks as "the roots from which the Exhibit Format series springs." NN to David Brower, 22 September 1965, Nancy Newhall Papers, GRI. For an example of Newhall's treatment of popular media, see Newhall, "Television and the Arts," Parnassus 40, no. 4 (1940): 37 38, doi: $10.2307 / 772164$.

${ }^{4}$ Nancy Newhall and Ansel Adams, The Pageant of History and the Panorama of Today in Northern California (San Francisco: American Trust Co., 1954); Death Valley (San Francisco: Five Associates, 1954); Mission San Xavier Del Bac (San Francisco: Five Associates, 1954).

5 For excerpts from the correspondence related to Newhall's work process in the early stages of the exhibition's development, see David Featherstone, "This Is the American Earth: A Collaboration by Ansel Adams and Nancy Newhall," in Ansel Adams New Light: Essays on his Legacy and Legend, ed. Michael Read (Carmel: Friends of Photography, 1993), 65.

${ }^{6}$ AA to Walter Starr, 23 August 1962, Sierra Club Members Papers, BANC MSS 71/295c, carton 2, folder 41, Bancroft Library; NN to AA, 21 February 1952, AAA at CCP.

${ }^{7} \mathrm{NN}$ to AA, 2 August 1954, AAA at CCP.
} 
Adams to "make it clear to everybody that this is not the show. Nobody in his right mind could possibly stand on his hind legs and read all this. This is the argument and organization." 8

While other projects consumed Adams's and Newhall's creative energies following 1954, it was Adams who sustained the idea of making the exhibition TITAE into a book. As early as January 1955, before the opening of the exhibition TITAE, Adams and Newhall made failed attempts to secure a publisher for the book TITAE. ${ }^{9}$ But over the next few years, Adams held onto his conviction that the message and photography in the exhibition should be eternally preserved in book form. At a time when few museums were exhibiting photography, books had provided Adams and Newhall with a platform to display and market fine art photography. Adams in particular had achieved recognition and commercial success through his photographically-illustrated books, and additionally, Newhall had used the book form to promote the work of important modernist photographers. By 1956, Newhall was working on the logistics of the TITAE book's format and cost, with the prospect that it would be funded by the USIA who had recently agreed to tour the exhibition. 10

However, it seems that the real groundwork for the book began in July 1957, upon Adams's return from a meeting in Aspen, Colorado with Newhall and representatives of the USIA about $A$ Nations of Nations. ${ }^{11}$ Feeling particularly motivated by news of the success of the TITAE exhibition's international tour, Adams was thrilled to report to the exhibition's benefactor, Walter Starr, that "the American Earth exhibit in Tokyo seems to be causing a lot of comment as it has everywhere. I strongly feel we should do the proposed book!"12 Adams suggested to Starr that they either form a syndicate to fund the book's production or persuade the Sierra Club to publish it, although the latter

${ }^{8} \mathrm{NN}$ to AA, 2 August 1954, AAA at CCP.

${ }^{9}$ Anne Hammond, Ansel Adams: Divine Performance (London; New York: Yale University Press, 2002), 114. Newhall and Adams tried to find a publisher for the book again around September 1956, considering both Alfred Knopf and Five Associates; NN to Michael Barjansky at the USIA, 22 September 1956, AAA at CCP.

${ }^{10} \mathrm{NN}$ to Michael Barkansky at the USIA, 22 September 1956, AAA at CCP.

11 Newhall's exhibition Volks aus Vielen Volkërn (A Nation of Nations) was a group exhibition of photographs and historical artefacts on the theme of American democracy, organized by Newhall as curator and designed by Herbert Bayer. It was part of the celebration of the inaugural opening of the Congress Hall in Berlin, which was conceived during the International Building Exposition of 1954, and was built to symbolize the alliance and shared democratic ideals of America and Germany during the Cold War. The opening of the building was celebrated from 19 September to 1 October, 1957 with Newhall's exhibition and an impressive program of art performances and lectures. Berlin Congress Hall programme, Nancy Newhall Papers, box 241, folder 9, GRI. In the literature, Hammond incorrectly stated that the A Nation of Nations was exhibited in 1959; cf. Divine Performance, 117.

12 AA to Walter Starr, 18 July 1957, AAA at CCP. 
seemed unlikely to Adams due to the expense of national distribution. ${ }^{13}$ Reaching the widest audience was of utmost importance to Adams, who had a deep personal connection to the national parks and would have also recognized an opportunity to market his photography. Beginning in August 1957, Adams took it upon himself to secure a publisher and distributor, first approaching editor Paul Brooks at Houghton Mifflin, with whom he had worked in the past. ${ }^{14}$ In the end, the book was published by the Sierra Club with the help of a bequest from Marion Randall Parsons and a grant from the conservationist Max McGraw through the McGraw Foundation. ${ }^{15}$ The book was printed by Peter Convente at the Photogravure and Color Company, New York, and was completed by the end of December 1959 for publication in January 1960.16

According to a letter she wrote to Michael Barjansky at the USIA in 1956, Newhall recognized the opportunity to produce a book that would not only serve a didactic purpose, but would also prove that American photobooks were on par with the craft and quality of European photobooks. ${ }^{17}$ It would seem that the high price of these books would make them more suitable for a niche art market than a national awareness campaign, but Adams and Newhall insisted on maintaining the same standard of aesthetic quality that they had upheld for Adams's books and for photography as they thought it should be presented in the museum. It was part of their desire for photography to be recognized as a fine art. Adams had learned about the importance of fine print quality in his meetings with Strand and Stieglitz in the 1930s, and he would emulate this practice in his earliest books which contained superb photographic prints and reproductions. The photographs in Adams's first book, Taos Pueblo, were made on fine photographic paper and packaged in a specially dyed linen cover binding. 18 Five years later, in Making a Photograph, a "how-to" book on photography, Adams displayed tipped-in, varnished, photographic reproductions that gave the remarkable

${ }^{13}$ AA to Walter Starr, 18 July 1957, AAA at CCP.

${ }^{14}$ AA to Paul Brooks, 6 August 1957, AAA at CCP.

15 The McGraw Foundation contributed a total of $\$ 22,500$ to the book- a $\$ 12,500$ grant in addition to a $\$ 10,000$ advance to the order of the Sierra Club. McGraw Foundation to David Brower, 21 May 1959, Sierra Club Office of the Executive Director Records, BANC MSS 2002/230c, carton 21, folder 42, Bancroft Library. It should be recognized that Adams often used personal funds to develop Sierra Club projects and had contributed approximately $\$ 750.00$ to the book. Additionally, neither Adams nor Newhall were remunerated for their time on the project, but did receive royalties from the sale of books. AA to Brower, 6 February 1958, AAA at CCP.

${ }^{16}$ AA to David Llewellyn, 18 December 1959, Sierra Club Members Papers, BANC MSS 71/295c, carton 1, folder 4, Bancroft Library. Up until December 31, 1959, the book was sold on a pre-publication price. Although completed at the end of 1959, the book was copyrighted 1960 since it was officially published in the new year.

17 NN to Michael Barjansky at the USIA, 22 September 1956, AAA at CCP.

${ }^{18}$ Ansel Adams and Mary Austin, Taos Pueblo (San Francisco: Grabhorn Press, 1930). 
illusion of original photographic prints. ${ }^{19}$ It is worth mentioning here, that as loyal followers of Alfred Stieglitz, both Adams and Newhall revered the individual and unmanipulated fine photographic print. Adams meticulously controlled the tonal contrast of the book's reproductions, and he was not satisfied with the first print run of the book. He requested for the book to be reprinted in early January of 1960 to correct any images that were not reproduced to achieve his desired standard.20

The book's physical characteristics and design served as a model for the succeeding nineteen volumes of the Sierra Club Exhibit Format published from 1960 to 1968.21 The book This Is the American Earth measured 13 1/2 by 10 1/4 inches, containing eighty-five rotogravure reproductions on eight-nine pages of heavy enamelled dull-finish paper. ${ }^{22}$ The covers were green cloth-bound with the title blind stamped on the bottom left of the cover and stamped in gold on the spine. The front of the white dust jacket reproduced the final image in the book, Aspen, Northern New Mexico (1958), with the title of the book as well as Adams's and Newhall's names set in Arrighi, black, upper case type below the image. The remainder of the book was set in Centaur. The book's size not only reflected the stylistic conventions of well known European photobooks, such as Henri CartierBresson's Les Européens, Photographies published in France five years before TITAE, but also enabled Adams and Newhall to print the images with the highest reproduction quality to closely resemble the look of original photographic prints. ${ }^{23}$ It is in these ways that Newhall and Adams fashioned the book TITAE into the finest example of photobook production and graphic art, carrying the high price of $\$ 15.00$ upon its release on January 1, 1960.24 Although the book did not in any way duplicate the layout of the exhibition panels, the name "Exhibit Format" evoked a fine art museum experience of viewing individual pieces in a slow and meditative manner, in contrast to

${ }^{19}$ Ansel Adams, Making A Photograph (New York: The Studio Publications, 1935).

${ }^{20}$ AA to Peter Convente, Brower, and NN, 10 January 1960, AAA at CCP.

${ }^{21}$ Brower directed the production of the remainder of the series, with Adams and Newhall contributing to some of the volumes.

22 The type of paper was called Warren offset enamel dull.

${ }^{23}$ Henri Cartier-Bresson, Les Européens, Photographies (Paris: Verve, 1955). The Newhalls admired the work of Cartier-Bresson and included him in their book Masters Of Photography (New York: George Braziller, Inc., 1958). Adams wrote that "to get the best results on Gillick's Heidelberg Press, the size should be 10 1/4 X 13 1/2 inches." AA to NN, 17 January 1958, AAA at CCP.

${ }^{24}$ Until December 31, 1959, the book had a pre-publication cost of $\$ 12.50$. For the first printing of 10,000 books, the unit cost to produce was relatively high at $\$ 3.50$. AA to David Llewellyn, 18 December 1959, Sierra Club Members Papers, carton 1, folder 4, Bancroft Library. 
the visual overload of picture magazines. ${ }^{25}$ In addition, the size of the book's reproductions closely corresponded to the size of typical exhibition prints of the era, notwithstanding the enormous enlargements made for exhibitions such as The Family of Man. ${ }^{26}$

In the book TITAE, Newhall integrated the work of thirty-two photographers with her own writing, as well as selections from historical and contemporary sources, some of which had appeared in the exhibition. The book contained a broad spectrum of nineteenth- and twentieth-century images made by well-known and unidentified photographers. The contemporary camp included photographs by Ansel Adams, Werner Bischof, Margaret Bourke-White, Wynn Bullock, Philip Hyde, Eliot Porter, Arthur Rothstein, Gerry Sharpe, Edward Weston, Minor White, Cedric Wright, and others. ${ }^{27}$ Newhall's layout varied, with the double-page spread containing anywhere from one to four photographs varying in size and often asymmetrically arranged. For example, in some cases two facing images were positioned at different distances from the gutter with borders around one image and a partial bleed on the other image, and in other cases a single photograph may be printed over the gutter to occupy three-quarters of the double-page spread. In a few instances, three or four small photographs were arranged vertically on a single page or balanced symmetrically across a double-page spread. The design closely resembled the conventions of the illustrated press, although the text never appeared in a succession of columns, but rather centred in the empty white spaces above, below, or beside the photographs.

Newhall viewed the book as an opportunity to revise the content of the exhibition, remarking in separate letters to the Sierra Club Editorial Board and the USIA that she wanted to improve "many of the passages in the show text that I never solved to my own satisfaction," and to deliver a more comprehensive account of the conservation concept by adding "references to past and present in

${ }^{25}$ Hammond offers a slightly different interpretation of the Exhibit Format, describing "the experience of an exhibition of pictures and text transferred to the page, perhaps carrying an overtone of evidence as offered to a court of law rather than a book placed on a coffee table." Divine Performance, 115.

${ }^{26}$ Since the original photographic prints from the exhibition TITAE have not been located and may no longer exist, an exact measurement of the range of print sizes has not been possible. However, as two examples, Newhall requested a 16 x 20 -inch print from Edward Steichen and John Morris of the Henri CartierBresson photograph, and an $11 \times 14$-inch print of Margaret Bourke-White's photograph for the exhibition. To compare, the largest reproductions in the book spanning the double-page spread are 20 inches long, and the majority of the photographs are not reproduced under 9 inches on the horizontal dimension. Various correspondence from Newhall, folder "TITAE 1955, Early Correspondence," [Jan-May 1955], AAA at CCP.

27 The list is not exhaustive. For a complete list of photographers and their works, see Adams and Newhall, This Is the American Earth (San Francisco: Sierra Club Books, 1960), xviii. 
other nations and continents." 28 While the book was expanded conceptually, it did not increase in the amount of text and number of images. A close examination of the overall differences between the two TITAE productions reveals that Newhall actually omitted images and scenarios appearing in the exhibition that may have seemed repetitive in book form, likely due to the restricted book length. For the book, Newhall selected text and photographs that would generate the most immediate and dramatic impact on the viewer through the double-page spread. Thus, the book contains seventeen fewer images than the exhibition did, and only thirty-two imagesapproximately one third of the exhibition prints - were also part of the exhibition.

In the process of revising from exhibition panels to pages, Newhall's writing style became less factual and incorporated new allusions to religious and mythical narratives comprised of an array of archetypal characters such as Eve, Satan, Faust, Lillith, Prometheus, and Osiris, to name a few. Thus, the exhibition's focus on American history, organizations, and important figures was largely replaced with an allegorical presentation of the American conservation movement and the problems faced by a modern society disconnected from nature. Featherstone rightly pointed out that the book conveyed "the need for a more broadly based environmentalism," as Newhall introduced new topics from the field of conservation such as population growth and pollution, which later became critical issues in the gradual shift from America's conservation movement to a modern environmental movement during the 1950s and 1960s. ${ }^{29}$ David Brower played a significant role in the addition of these topics, and he contributed to Newhall's process of drafting and editing the book. This chapter will address Brower's specific contributions to the book in a later section devoted to describing in what ways the book reflected a variety of perspectives on conservation.

A promotional pamphlet distributed by the Sierra Club in December 1959 announced the book's ambitious and timeless theme in this way:

Moving from a paradise lost in the Old World, our fathers brought forth upon this continent not only a new nation, but also an ability to change, at an ever-increasing rate, the face of the earth. To consider what the change portends for our standard of life - our very survival—Nancy Newhall has written a compact, vital, and moving text. ${ }^{30}$

${ }^{28}$ NN to Editorial Board, 1 April 1958, NN at CCP; NN to Michael Barjansky, 22 September 1956, AAA at CCP.

${ }^{29}$ Featherstone, "A Collaboration," 69.

${ }^{30}$ Undated pamphlet, signed by David Brower, "The Most Important Announcement the Sierra Club has Ever Made," [December 1959], Sierra Club Office of the Executive Director Records, carton 21, folder 43, Bancroft Library. 
While Newhall retained her previous historical perspective of environmental issues, she considerably expanded the timeframe, extending it back to the point of Earth's creation, and into the future when mankind would be forced to leave planet Earth to begin a new civilization. She divided the material into six chronological chapters: (1) Brief Tenant; (2) New World; (3) The Machine and a New Ethic; (4) The Mathematics of Survival; (5) Dynamics; and (6) The Crucial Resource. However, it was Newhall's intention that each chapter or smaller sequence within the chapter could be appreciated on its own independent of the rest of the book. In a letter to Brower, Adams asserted that the book was not designed to be "read from cover to cover," but rather to be experienced as "a series of emotional impacts" that were created by the book's interior flow of sequence and layout. ${ }^{31} \mathrm{He}$ characterized it as a combination of "picture book" and "extended poem."32 Judging by Adams's justification of the content of the book, it seems that the club wanted a more straightforward account of conservation. However, Newhall's signature style of combining photographs and words would deliver an emotional presentation on conservation rather than a chain of factual arguments.

The club was likely offering its criticism with a particular end goal in mind, as it hoped to send the book to members of Congress to help pass the long-awaited Wilderness Bill. ${ }^{33}$ While Adams agreed that the book should reflect recent developments in nature conservation issues that were not represented by the exhibition, he was unwavering on the aesthetic front. On several occasions, both privately to Newhall and openly to the Sierra Club, Adams adamantly expressed that all decisions regarding the TITAE project strictly belonged in the Adams-Newhall domain. ${ }^{34}$ As Newhall's close friend and collaborator, Adams fervently supported her vision and continuously reminded the Sierra Club that "the project is ethically Nancy Newhall's." 35 The Sierra Club marketed TITAE as a "coffee-table book," but the charged nature of its text, its direct treatment of world issues, and its strong tone of disillusionment mixed with romantic idealism made the book less of a picture story and more of a serious photobook that reacted to the problems of post-war America.

${ }^{31}$ AA to Brower, 15 March 1958, AAA at CCP.

32 Ibid.

${ }^{33}$ Brower to NN, 7 February 1958, AAA at CCP. Two months earlier, on the occasion of presenting the book dummy to the Sierra Club Board of Directors, Adams urged Newhall to accentuate the importance of wilderness in the book in order to support the bill. AA to NN, 16 December 1957, AAA at CCP, cited in Hammond, Divine Performance, 127.

${ }^{34}$ AA to Brower, 15 March 1958, AAA at CCP. For more information on the Adams-Newhall collaboration, see Featherstone, "A Collaboration," 63-73.

${ }^{35}$ AA, David Brower, and August Frugé to NN, 16 January 1958, AAA at CCP. In part, this may have been a strategic move on behalf of Adams, since Newhall was not a member of the Sierra Club and could not be expected to accommodate the club's wishes. 


\subsection{AESTHETIC INFLUENCES}

By the time it was published in 1960, the design of TITAE had come a long way from the formal page layouts of Newhall's landmark photobook, Time in New England, in which she and Paul Strand had experimented with the "additive caption" through a unique sequencing of historical texts and photographs. ${ }^{36}$ In her introduction to the book in 1950, Newhall stated their joint aims:

The usual pairing of text and photograph, or the insertion of a sheaf of photographs at regular intervals struck us as monotonous. Apt or literal juxtapositions we avoided as static.... Throughout, our purpose has been to create a portrait more dynamic than either medium could present alone. ${ }^{37}$

Despite the complex integration of the two media, the layout was simple and subdued, with each image centred on the page. This resulted in minimal variety for the double-page spread-image facing image, image facing text, and text facing text-throughout the 249-page book. The book perhaps was notable at the time for its elegant visual statement, which stood in contrast with the overcrowded pages of the illustrated press. However, compared to Time In New England, TITAE employed the additive caption through a more dynamic composition that combined several images and text on a single page. As Newhall wrote in her 1952 Aperture article "The Caption: The Mutual Relation of Words/Photographs," she believed meaning was created by "neither words nor photographs but only in their juxtaposition," and in the ten years between Time In New England and TITAE, she had moved closer to a literal translation of her manifesto by dramatically reducing the physical space between image and text within the book. ${ }^{38}$ For example, a single page in the book TITAE displayed an image embedded between two blocks of text, or several images appeared around a block of text across the double-page spread.

Departing from her previous publications, Newhall's layout for TITAE was heavily influenced by the illustrated press. As Hammond rightly pointed out, "one of the influences on the conception of the book was the presentational style of Life magazine," as well as The Family of Man exhibition and book. ${ }^{39}$ While both the books TITAE and The Family of Man were clearly influenced by the illustrated press, they differ in subtle but important ways. In planning The Family of Man, Steichen openly embraced the conventions of popular picture magazines, and as historian Eric Sandeen remarked, the idea for Steichen's exhibition and book may have been inspired by a 1947 series of

36 Nancy Newhall, "The Caption: The Mutual Relation of Words/Photographs," Aperture 1, no.1 (1952): 19; Paul Strand and Nancy Newhall, Time In New England (New York: Oxford University Press, 1950).

${ }^{37}$ Nancy Newhall, forward to Time In New England, vi.

${ }^{38}$ Nancy Newhall, "The Caption," 19.

${ }^{39}$ Hammond, Divine Performance, 115. 
photo-essays in Ladies Home Journal entitled "People are People the World Over," conceived by the picture editor John G. Morris. ${ }^{40}$ With Wayne Miller's assistance, Steichen drew heavily upon the Life files for the exhibition, and designed the book with a similar editorial aesthetic as magazines. One of the most utilized layouts in the book contains six images across a double-page spread — two images occupying roughly the top half portion of the double-page spread and four smaller images in a horizontal sequence below, emulating the look of a film reel or cinematic montage. ${ }^{41}$ On average, this horizontal sequence presented up to six images, to make a total of eight images across the double-page spread. ${ }^{22}$ Occasionally, to emphasize the human themes in the photographs, short lines of text, selected by writer Dorothy Norman, appear alongside the images. In the most complex layouts, the double-page spread contains eighteen images, and in one instance, several images overlay one enlarged image with text printed across the image areas. ${ }^{43}$ Like the picture editors of magazines who designed photo-essays, Steichen liberally cropped, enlarged, reduced, and changed the contrast of the photographs to suit the mood and storyline. In addition, like the magazines, The Family of Man book contained small photograph credit lines that did not highlight the identity of the photographer as the creator, and did not reflect original photograph titles. Instead, Steichen replaced each title with the geographic location represented in the photograph, in order to construct an exhibition-sized picture story about a world family.

Adams and Newhall, certainly sympathetic to some of the photographers' wishes to retain the dignity of the original fine print, maintained a more equal proportion between the negative and the reproduction size in the book TITAE, thus restricting the number of images that could appear across the double-page spread. Although Adams and Newhall selected photographs to advance their theme, they ensured that photographers' names, original titles, and image sources, were clearly visible, even after the President of the Sierra Club complained that the titles detracted from the

${ }^{40}$ Eric J. Sandeen, Picturing the Exhibition: The Family of Man and 1950s America (Albuquerque: University of New Mexico Press), 25. In his memoir, John G. Morris recounted how he conceived the picture series, "People Are People the World Over," on the universality of family life, in 1947. The Family of Man's similar theme and sentimental approach are easily recognizable in the ninth part of the series, "This Is the World At Home," in which the text read, "By such small tokens these twelve families, strangers in a baffling world, are familiar to one another." Steichen also employed a similar layout as this photo-essay in The Family of Man book. John G. Morris, Get the Picture: A Personal History of Photojournalism (Chicago: University of Chicago Press, 2002), 112-113; "This Is the World At Home," part 9, People Are People the World Over, Ladies Home Journal, January 1949, 44-45; cf. The Family of Man (New York: The Museum of Modern Art, 1955), $94-$ 5.

${ }^{41}$ Edward Steichen, The Family of Man, 38-9. As another example, see pages 116-17.

42 Ibid., 136-37. As another example, see pages 164-65.

43 Ibid., 94-5, 48-9. 
overall effect. ${ }^{44}$ In addition to the titles, the book's front matter included a page entitled "Photographers" that listed the photographers' names in alphabetical order, the original titles of their works, and the page on which each image could be found. Adams and Newhall showed a great amount of respect for the photographers' intentions, and while Adams maintained complete control over the printing, Newhall happily conceded to any of the photographers' requests for title changes in the book's second edition printed in July 1960.45

As Hammond has also noted, the image selection for the book TITAE was influenced by The Family of Man exhibition, which Newhall had the opportunity to see in January 1955 at MoMA, as well as during its presentation at George Eastman House in July 1956.46 At the beginning of the TITAE book's first chapter "Brief Tenant," Newhall presented a photograph of a stellar nebula from the Palomar Observatory, bearing a striking resemblance to the stellar nebula photograph from the Lick Observatory which appeared in The Family of Man exhibition. The Family of Man book also presented the stellar nebula photograph as its frontispiece in full bleed on the left-hand page facing a smaller and roughly-centred image of an abstract nature study. Newhall used this identical layout for her presentation of the stellar nebula photograph in TITAE. Yet, from exhibition to book, Newhall actually omitted three of the photographs included in the original exhibition TITAE that had also been shown in The Family of Man exhibition and book. ${ }^{47}$ Therefore, the book TITAE and The Family of Man exhibition and book share only one image, William Garnett's Snow Geese over Buena Vista Lake, California (p. 63). Newhall had used the stellar nebula photograph in two other projects before she began drafting the book TITAE. The photograph appeared in her exhibition $A$ Nation of Nations, as well as its travelling panel version, I Hear America Singing. 48 Significantly, the installation photographs from the exhibition A Nation of Nations reveal some of the same photograph pairings that appear in the book TITAE, such as the William Garnett sequence in the third chapter "Mathematics of Survival" (p. 36-37) as well as a double-page spread in the fifth chapter "Dynamics" (p. 56-57).

${ }^{44}$ Dick Leonard to AA, 12 Jan 1960, AAA at CCP.

45 In the second printing, Newhall corrected the titles that accompanied the photographs by Dick McGraw, Ray Atkeson, and William Garnett. NN to Brower, 25 July 1960, AAA at CCP.

${ }^{46}$ Hammond, Divine Performance, 116.

${ }^{47}$ Ibid. The three other photographs that the exhibition TITAE shared with The Family of Man exhibition and book were Henri Cartier-Bresson's Mohammedan Women Praying (TITAE Panel Two), Werner Bischof's Famine, India (TITAE Panel Two), and Barbara Morgan's Girl with Recorder (TITAE Panel Thirteen). Hammond listed these photographs in Divine Performance but left out the Bischof photograph.

${ }^{48}$ Undated installation photographs of $A$ Nation of Nations, Nancy Newhall Papers, box 241, folder 1 , GRI; Undated installation photographs of I Hear America Singing, Nancy Newhall Papers, box 242, folder 2, GRI. 
Additionally, Hammond identified similarities between Newhall's text in TITAE and the text selections by Dorothy Norman for The Family of Man book, yet there are many important differences to be found between them. Finding similarities between the two texts, Hammond wrote that Newhall's text "shared a declamatory quality with the proverbs and poetic excerpts compiled by Dorothy Norman for Steichen's The Family of Man."49 On the contrary, Newhall's text formed a lengthy narrative, mainly composed of her own free-form prose that was then interspersed with short selections from historical works. Newhall's writing style closely aligned with the lengthy free verse of Walt Whitman. It is quite possible that Newhall was influenced by Whitman while creating the book, since she had recently finished organizing the exhibition A Nation of Nations, which was composed entirely of selections from Whitman's Leaves of Grass.

In contrast, Norman's selections for The Family of Man were brief, one- or two-line excerpts that thematically introduced a grouping of photographs, and there was no textual exposition or narrative that linked the excerpts. Norman sought out universal texts such as the Bible and Bhagavad-Gita, while Newhall primarily chose works by American writers and historical figures, with a strong emphasis on New England sources, which likely originated from her previous work with Paul Strand on Time in New England. The next section of the chapter will detail the ways in which Newhall integrated words and images to produce a timeless argument for conserving the American wilderness, and will highlight the ways in which the book preserved the content of the exhibition or diverged from its viewpoint and presentation.

\subsection{DESCRIPTION AND ANALYSIS}

\section{The Introduction}

The book opens with a visual "Overture" of four double-page spreads, in which Newhall introduced the wilderness and its spiritual benefits to humans before the book's title page spread and front matter (p. i-ix). For the overture, Newhall effectively transplanted Panel One of the exhibition into book form, making only minor changes to the text and keeping four of the panel's six images. The fourth double-page spread presents a different image selection alongside Newhall's text from the exhibition that read, "What is the cost of freedom," employing Eliot Porter's photograph Bird in Flight and Adams's Clouds and Peaks, Glacier National Park to accompany the text (p. viii-ix). With this combination of words and images, Newhall gives the impression of a boundless form of

${ }^{49}$ Hammond, Divine Performance, 115. 
freedom in nature that humans can be inspired by as observers of the natural world. The two images share a feeling of movement with the clouds travelling over mountains and the bird appearing as though it has out-flown the clouds to clearer sky. The precursor to this arrangement originated in Panel One, in which Newhall juxtaposed a butterfly specimen with Adams's photograph Nevada Fall, Yosemite National Park to illustrate the interrelatedness of two contrasting scales in nature.

For Adams and Newhall, the idea of an "Overture" first appeared in their 1959 book Yosemite Valley, a collection of Adams's photographs accompanied by Newhall's selections of his writing. Judging by the temporal proximity of the two books, it is not surprising that TITAE's page layouts in many ways resemble the design of Yosemite Valley. The musical reference to an "overture" does not seem to be the most suitable term for TITAE's introductory sequence, which more closely parallels the "cold open" in a television show or movie, which precedes the title sequence. ${ }^{50}$ Nevertheless, like the exhibition, the sequence effectively introduces the natural scene as a source of freedom, spiritual fulfillment, material wealth, and American identity. The four double-page spreads lead into a title page spread displaying an image of Half Dome in wintertime with "This Is the American Earth" printed in upper case Arrighi typeface below it (p. x-xi).51 The photograph captures the moment in which a strong gust of wind lifts snow off the cliff face. It is an image that reveals both the magnificent enormity and the delicate details in nature. Newhall chose one of the most iconic landmarks in Yosemite Valley for the title page, endowing the American earth and its people with a monumental quality.

\section{Brief Tenant}

Like Panel Two of the exhibition, the first chapter "Brief Tenant" chronicles the downfall of the earliest human civilizations who abused the earth's natural resources to sustain their survival. However, for the book, Newhall began her narrative farther back in time at the point of Earth's formation, arguing that the human race is insignificant in relation to the interminable forces of nature that have acted upon Earth since its creation. The chapter's theme of man as a "Brief Tenant"

50 U.S. Camera's review of TITAE also recognized the influence of television on the "Overture." Ed Hannigan, ed., "New Books," review of This Is the American Earth, by Ansel Adams and Nancy Newhall, U.S. Camera, September 1960, 26.

51 The photograph is Halfdome, Blowing Snow, Yosemite National Park, California, ca. 1955. 
on earth was not newly researched, as Newhall had expressed a similar idea in her 1953 Aperture article "Controversy and the Creative Concepts." She wrote, "The proper study of Man in the West is the powers of the functions of the earth, and how he may live with them during his brief tenancy.... In man as in nature, the same forces are at work." 52 Thus, in the first chapter Newhall established that humanity, like nature, was subject to the continual forces of life and death.

In the opening double-page spread, Newhall displays two images to convey the early history of the planet. On the left-hand page, a full bleed image of Spiral Nebula from the Palomar Observatory depicts space, complementing Newhall's text on the facing page, which imagines the moment of Earth's creation "seven billion years ago" as a "cosmic cloud" and "the vast light of Creation" (p. 1). On the right-hand page, Spiral Nebula is visually mirrored on a smaller scale by Minor White's Rock Pool. The glaring spot of sunlight depicted in the image seems to illustrate the text, in which Newhall characterizes man's existence on Earth as brief and transitory, "a meteor's flash" (p. 1). Newhall's treatment of the human race on this opening double-page spread starkly contrasted with the exhibition panel, which adopted an anthropocentric viewpoint and described the creation of mankind as "a comet rising." Rock Pool continues to illustrate various aspects of Newhall's text, which emphasizes man's humble beginnings as a low animal form before becoming recognizably human. Unlike in the exhibition, in which she remained grounded in fact, Newhall mythologizes the early history of Earth and the human race, with a line of her text enquiring, "What were we when we saw a phoenix hatch in flame, a serpent fly?" (p. 1).

On the next page, Newhall advances chronologically through the stages of man's evolution with Adams's Petroglyph, Hawaii, depicting a pictorial representation of a human made with leaves and carved stone. The composition of the image, as well as the contrast between the dark background and bright leaves, makes Petroglyph, Hawaii resemble Spiral Nebula from the previous page. Through this sequence, as well as Newhall's text, Adams and Newhall imply that humans have now become the center of "the radiant vernal earth to which / we waked as king!" (p. 2). Yet, as Newhall's text continues, Petroglyph, Hawaii becomes an image of man as a basic and mortal creature that has been expelled from the Garden of Eden: "What was our sin! [...] 0 strange creation! Why should new forms of love, evolving, demand / new forms of death?" (p. 2). Petroglyph, Hawaii sets the tone for a longer section in which Newhall emphasizes the mortality of the human race, describing the collapse of various early human societies as a result of their overuse

52 Nancy Newhall, “Controversy and the Creative Concepts," Part I, Aperture 2, no. 2 (1953): 12. 
of natural resources. While this content is based on Panel Two of the exhibition, in the transformation of her exhibition text to the book format, Newhall made considerable omissions. Where the exhibition referred to nine episodes of environmental ruin occurring in nine different ancient cultures, the book referred to only six episodes and contained new selections from historical texts that dramatized Newhall's narrative of human catastrophe.

Introducing the main exposition of the chapter, like the exhibition, the book's text declares, "Brief tenant! / Already across the continents Man's record of ruin lies very old" (p. 4). The statement is followed by a long excerpt from the ancient Egyptian poem The Admonitions of Ipuwer that relates the rise of chaos, starvation, and cannibalism in an ancient society to a series of natural disasters (p. 4).53 Directly following the quote, Newhall recounted the fall of Mesopotamia, in her own words, and presented two images of ancient ruins that correspond to the time period and geographic locations reflected in the text. Francis Frith's Colossi, Nubia occupies a half page and depicts two statues from the mortuary temple of Amenhotep III in Egypt. Balancing this image on the facing page is James Robertson's The Acropolis, Athens, also occupying a half page. Both of these photographs were originally produced as souvenirs in the 1850 s for a predominantly Western tourist industry, and would have appealed to consumers as archaeological studies and evidence of an exotic and romanticized past. However, the tragic mood of the Ipuwer text accentuates the weathered appearance of the statues and temple, turning them into signs of human decay and a lost civilization.

The book's treatment of the rise and fall of humanity becomes increasingly dark with Werner Bischof's Famine, India on the next page (p. 6). The close-up image of a starving woman holding a malnourished child occupies an entire page and abruptly pulls the reader out of the ancient past and into the present. It is the first overt depiction of human destitution in the book, as well as the first reference to a contemporary post-war issue. The photograph was taken in April 1951 during the American relief operation in India following a severe period of drought and flooding that caused famine in the state of Bihar. The facing page of text guides the reader to interpret the image.

53 The excerpt appears to be taken from John A. Wilson's translation of The Admonitions of Ipuwer, in Ancient Near Eastern Texts Relating to the Old Testament, $2^{\text {nd }}$ edition, ed. James B. Pritchard (Princeton, New Jersey: Princeton University Press, 1955), 441-44. In TITAE, Newhall frames The Admonitions of Ipuwer as a true historical event. While floods of the Nile River in thirteenth century BC did in fact severely impact Egypt's economic, social, and political stability, the poem has not been conclusively accepted among scholars as evidence of this occurrence. Fekri A. Hassan, "Nile Floods and Political Disorder in Early Egypt," in Third Millenium B.C. Climate Change and Old World Collapse NATO ASI Series Volume 49 (Berlin: Springer Berlin Heidelberg, 1997), 2, doi: 10.1007/978-3-642-60616-8_1. 
Selecting a long excerpt from the ancient Roman scholar Tertullian, describing "hungry multitudes" and a "teeming population" that is "burdensome to the world," Newhall framed the Bihar famine issue in terms of overpopulation fears (p. 7). Bischof's photograph was not originally intended to express this anxiety. The other photographs he took in Bihar convey America's generous response to a nation in need and also serve as convincing social documents of human suffering that would compel people and government leaders to offer humanitarian aid. In the book, Newhall does not express sympathy towards the woman and child. Instead, she uses the image in a sensationalist manner, fashioning the woman into an archetypal "specter of famine" to evoke fear around food security and global population growth (p. 7).

The first chapter ends on a more positive note with Clarence Kennedy's Renaissance Man, a close-up image of a statue of a determined young man (p. 9). The text across this double-page spread summarizes the fall of the last ancient civilization due to human overuse of the land, and the subsequent rise of new intellectual pursuits throughout the fifteenth century. Together, the image and text symbolize the persistent hope and ambition of mankind, with the empty eyes of the statue seeming to gaze endlessly ahead to future "dream[s] of new ways to live" (p. 8). Having depleted the continent's resources, the people's "memory of wilderness had vanished / and the only hope of freedom lay in conquest" (p. 9).

Unlike the exhibition, which ended with a cathartic image of women praying in the sun, "Brief Tenant" ends on an inconclusive note. By contrast, Clarence Kennedy's Renaissance Man is a cold and empty photograph of man's ambition to conquer new land, rather than worship and protect the one on which he already stands. Preserving the exhibition's theme of Panel Two, the first section of the book contends that the natural environment is essential to man's progress and survival. With the chapter's focus on human mortality, an "age of the dance of death," the book begins with a serious warning against nature's misuse.

\section{New World}

The second chapter of the book "New World" follows the theme of Panel Three from the exhibition, conveying the arrival of Europeans in the American continent in the seventeenth century and the settlers' decimation of the land as they constructed settlements throughout the Industrial Revolution. One main difference in the book was that Newhall added a discussion of the rise of the 
modern city and its subsequent negative effect on man's relationship to the wilderness. However, the first double-page spread in the chapter contains the same two Adams images and William Bradford excerpt from the opening of Panel Three (p. 10-11). ${ }^{54}$ Only the text on the facing page that accompanies Adams's Mortar Holes, Yosemite National Park has been slightly altered to reflect more strongly the American narrative of Manifest Destiny, with Newhall characterizing the American continent as an "Eden" where American Indians "lived on the wild earth lightly" in "paradise" (p. 11).

The book continues to reflect the settlers' belief in Manifest Destiny. In the exhibition, where Newhall's text read, "Here any man could hew his own home and his own freedom," the corresponding text in the book reads, "Here any man with ax and gun could live, clear his own fields, hew his own home, win for himself a long forgotten birthright—independence" (p. 12). Newhall selected the sweeping landscape of Adams's Moro Rock, occupying three-quarters of the double-page spread, to symbolize American independence and the settlers' feeling of unlimited opportunity "over the next ridge," with the rock in the foreground of the image forming a crest to peer beyond (p. 12-13). As she had in the exhibition, Newhall chose to insert texts by Roger Williams and John Wise which convey the American wilderness as inspiration to the pursuit of human freedom. 55

On the next double-page spread, employing the exhibition's arrangement of image and text, Newhall argued that the wilderness can provide humans with a positive experience of solitude (p. 14-15). Then, continuing to adopt the text from Panel Three, the book conveys the period of westward expansion in America that caused the eradication of the American Indians, animal populations, and wilderness lands (p. 16-17). In addition to reproducing Arthur Rothstein's Clearing, entitled Stumps and Rail Fence, Maryland in the exhibition, Newhall introduces two new images to accompany the text-Cross, Truchas, New Mexico by Adams and Scarcee Indian by the firm Boorne and May — to emphasize how the settlers' economic activities had an irreversible impact on the American Indians' culture and population (p. 16-17). On this double-page spread,

${ }^{54}$ The William Bradford excerpt that appears in the exhibition and book TITAE is from a modern version of the original text. William Bradford, History of Plymouth Plantation, rev. ed. by Samuel Eliot Morrison (1856; repr. New York: Alfred A. Knopf, 1952), 61.

${ }^{55}$ Roger Williams, Bloudy Tenent of Persecution For Cause of Conscience Discussed and Mr. Cotton's Letter Examined and Answered, rev. ed. by Edward Bean Underhill (1644; repr. London: J. Haddon, 1848), 214. The second excerpt is from John Wise, Vindication of the Government of New England Churches (1717; repr. Florida: Scholars' Facsimiles and Reprints, 1958), 61. 
Newhall presents the three images in an asymmetrical layout, and their smaller scale makes them appear as illustrations to the text.

As newly conceived material for the book, the next double-page spread builds to a din of factories and pollution, with Newhall's text describing how the growth of American cities has led to the separation of humans from the wilderness. Newhall selected Jacob Riis's Bandits' Roost, Lower East Side, New York City to illustrate the appalling living conditions in American urban centers at the end of the nineteenth century (p. 19). The narrow alleyway crowded with people contrasts starkly with the open landscapes and descriptions of solitude on the preceding pages. The value of experiencing nature in solitude to restore a spiritual connection between oneself and the universe was a main tenet of Transcendentalist writings by Henry David Thoreau and Ralph Waldo Emerson. For the book, Newhall chose longer selections from their writings to appear opposite Bandits' Roost, suggesting that Riis's image is as much a portrayal of economic poverty as spiritual poverty (p. 1819). ${ }^{56}$

The chapter ends on a similarly high note as Panel Three did, with the founding of America's first state and national parks. However, in the book, Newhall characterizes the national park as a "marvelous hell" and presents two landscape images by Adams_-Yosemite Valley, Thunderstorm and Old Faithful Geyser - that capture the powerful and threatening side of nature (p. 20-21). Through these images, Newhall conveys a wilderness that humans can only approach in "awe and humility," thus promoting a more harmonious relationship between man and nature (p. 20-21). Like Panel Three of the exhibition, the second chapter traces the growth of the American nation. However, in adapting the exhibition to book form, Newhall added an explicit aspect of human misery and a troubled modern society to further emphasize the human need for the national parks as a source of freedom, individuality, and spiritual enlightenment.

\section{The Machine and a New Ethic}

Following Panel Four of the exhibition, the third chapter of the book conveys the period of industrial development in America and its negative impact on the earth. Newhall made several

${ }^{56}$ Henry David Thoreau, “Chesuncook," The Atlantic Monthly 2, no. 8 (June 1858): 317;

Ralph Waldo Emerson, "Prospects," in Nature, rev. ed. by Kenneth Walter Cameron (1836; repr. New York: Scholars' Facsimiles and Prints, 1940), 93. 
changes in image selection and text for the book. It includes only three of the same images as the exhibition and does not contain as many facts about American history. "The Machine and a New Ethic" opens with a half-page image of Minor White's Ax and Plowed Field, Oregon. As the title reveals, the photograph depicts the way farmers cultivate soil for bountiful crops. However, Newhall's text places the image in the context of Americans who "conquered a continent," thus transforming the ax from a harvesting tool into a weapon used to destroy the land (p. 22). On the facing page, two nineteenth-century partial stereoviews, Wagon Train, Rocky Mountains, c. 1868 and Railroad Across the Plains, c. 1868 depict the land as prospective commercial real estate; to a nineteenth-century viewer, they would have represented America's wealth. However, Newhall's accompanying text carries a negative tone, recounting the period of commercial development in this manner: "Reckless, we tore at the last great virgin resources. / What did it matter what we wasted or exhausted?" (p. 23). In the chapter's opening sequence, Newhall used the double-page spread to show the transition from old farming practices in White's image to America's age of machinery, which severely depleted the nation's natural resources.

On the next double-page spread, the intimate format of the stereoviews is replaced with two nearly full-page images, Bill Sears's Cattle Driving, Arizona and Ray Atkeson's Log Pond, Oregon (p. 24-25). The sudden change in scale adds drama to the narrative, and without text, Newhall visually conveys how natural resource development grew to enormous proportions in the twentieth century. Following this, Newhall employed a similar arrangement of images and text as she did in the exhibition to demonstrate how uncontrolled commercial activity destroyed the wilderness. In support of her text, she selected four small images of mining, hunting, farming, and animal grazing, of which only one image appeared in the exhibition panel (p. 26-27).

From this long list of environmental problems, Newhall led to the founding of the American conservation movement. On a double-page spread mainly composed of text, Newhall delved into the ideological battles waged over the meaning and practice of "conservation." Greatly condensing the material, Newhall chose to highlight only the opposition between Gifford Pinchot and John Muir. She dramatized their antagonism and made it a universal point of contention by stating that theirs was "a conflict as old as the snake in Eden" (p. 29). In contrast, the exhibition portrayed a more dynamic and constructive conservation movement in which many actors and organizations with competing objectives engaged in an ideological "war for the very life of America." For the book, Newhall selected only two images from Panel Four and positioned them in a nominal space 
between her text. The absence of a strong visual impact across the double-page spread creates an inconclusive feeling that crescendos into the crisis of the 1930s in the following pages.

Newhall devoted a full-page of text to describing the human misery that resulted from poor resource management and farming problems during the Dust Bowl era. However, on the facing page, Margaret Bourke-White's Contour Plowing, a bold aerial view of farmland, illustrates the solutions and development projects that came out of the Great Depression (p. 31). While this appears to be hopeful, the next image Moon and TV Antennae, Hawaii by Adams serves as a dire warning alongside Newhall's text. With the image of the wire antennae against a black sky, Newhall suggested that the future for humans will be dark, as human ambitions will continue to grow until mankind is forced to inhabit another planet. The chapter closes with a plea to "come humbly, softly, to look, listen, learn, / to cherish and to shield" the natural beauty of the earth before it is too late (p. 32-33). "The Machine and a New Ethic" offered little of the positive and nationalistic mood that could be found in Panel Four of the exhibition, as it heavily focussed on the way machines contributed to human despair and environmental ruin. While fewer images may have been better suited to the book format, Newhall removed much of the vitality of the history of the American conservation movement expressed in the exhibition, with its variety of actors and clear examples of American innovation and spirit.

\section{The Mathematics of Survival}

Forming the climax of the book, the "The Mathematics of Survival" addressed the most urgent problems that faced post-war America. The section was newly conceived for the book and took no direction from the exhibition. Thirteen photographs accompanied by an apocalyptic text expressed the social and environmental problems caused by the atom bomb, pollution, water shortages, population increases, and poor urban planning. On the opening page, Newhall imagined a calamitous end to the world, with her text describing Dante Alighieri's descent into Hell and John Milton's fallen angels (p. 34). ${ }^{57}$ Above these references to epic poems in the text, an image of an obliterated sun in Adams's Thundercloud contributes to the cataclysmic mood. On the facing page, Newhall links this imagined collapse of modern society to the problems caused by the hydrogen bomb, with her text referring to a "columned cloud," and further declaring that "Death rides a ray,

${ }^{57}$ Dante Alighieri, Divine Comedy, vol. 1 Inferno; John Milton, Paradise Lost, bk. 1. 
an atom" (p. 35). Below the text, Adams's Trailer Camp Children gives the impression of human fear and links Newhall's poetic text to real human consequences.

On the subsequent double-page spread, Newhall simultaneously conveyed the problems of pollution and urban planning. Alongside her text, asserting, "Hell, we are building here on earth," she presented an image of the city of Los Angeles cloaked in smog, as though it was a modern hell. On the adjacent page, Newhall arranged three aerial photographs by Garnett of crowded tract housing, each called Housing Development, Los Angeles. In their original context, made on commission for the developers of Lakewood Park, these images were symbolic of America's remarkable innovation and prosperity after the Second World War. ${ }^{58}$ However, alongside Newhall's critique of the modern city, they convey the homogeneity of buildings and the visual monotony of the modern landscape (p. 36-37). To further her critique of urban sprawl, Newhall reproduced one of Garnett's aerial views Los Angeles on the next double-page spread in full bleed.

Los Angeles's flat urban landscape is replaced by a different geometry in Wynn Bullock's Erosion on the next page. It appears that Newhall selected the photograph for its unique point of view that shows both the surface and the inside of the earth, illustrating a variety of conservation issues that occur both in plain view and hidden from sight. Newhall's text describes the loss of wilderness to highways, dams, erosion, and finally to the less visible "plunder of this planet's crust" for fossil fuels (p. 40-41). On the facing page, Newhall focussed on the social consequence of poor urban planning and uncontrolled resource development with Henri Cartier-Bresson's Boy in Passage, Adalucia. The text in the half page below the image describes the loss of a nurturing environment for children who are "trapped in city corridors" and "enmeshed in suburbs" (p. 41). Much like the meaning of Riis's Bandits' Roost in the previous chapter, which also conveys an alleyway setting, Boy in Passage, Adalucia becomes an image about the spiritual and moral poverty of a modern society detached from nature.

The chapter then opens onto an overwhelming full-bleed image of Ferenc Berko's Bathers on the Ganges across a double-page spread (pg. 42-43). Without an accompanying text, Newhall highlighted the expanding size of the crowd through the full bleed, and on the subsequent page, she

58 "Lakewood California," The J. Paul Getty Museum Collection, http://www.getty.edu/art/ gettyguide/artObjectDetails?artobj=256209; "New Homes: 1,000 A Month," Business Week, September 9, 1950, 52-3, in Adam Rome, The Bulldozer in the Countryside Suburban Sprawl and the Rise of American Environmentalism (Cambridge: Cambridge University Press, 2001), 2. 
expressed overpopulation fears, declaring that "the needs of all these multitudes drives nations into madness" (p. 44). It is the same treatment of the population problem as in "Brief Tenant." Significantly, these two analogous moments in the book reflect America's broadening perspective on conservation issues after the war, as "increasing numbers of American strategists, including many top American officials, came to believe that the imbalance of people and resources around the world threatened American national security." 59 In Hammond's interpretation of Bathers on the Ganges, she rightly pointed to the irony of Newhall's criticism of the crowds by recognizing that the bathers flock to the river "seeking the same kind of spiritual renewal for which Sierra Club members might go to the High Sierra."60

At this point in the chapter, Newhall portended a hostile future in which the polluted environment causes humans to devolve into "a feeble race, misshapen, [and] febrile" (p. 45). She selected Crab Nebula to accompany her description of "a poisoned, gutted planet, rolling through dark noxious air," suggesting that Earth will end in radioactive dust and pollution, returning to a similar formative stage represented by Spiral Nebula in the first chapter. Although Newhall emphasized a gloomy reality in chapter four, she ended with an encouraging sermon that addressed the whole of humanity. Newhall's text celebrates the collective achievements of mankind and encourages humans to use the "burning brilliance" of their minds to reflect on the problems of the world and to find ways to "lie lightly on this earth" (p. 46). The full-page image of Sun Halo, Death Valley by Adams on the facing page appears to symbolize a new beginning with the reappearance of the sun. "Mathematics of Survival" was an imagined end to a modern American society faced with polluted cities, a scarcity of resources, crowds of people, and a weapon of mass destruction. Unlike any panel in the exhibition, this chapter created a mood of anxiety and fear in order to persuade the reader that preserving the wilderness was ultimately about preserving the future of humanity.

\section{Dynamics}

Composed of twenty photographs, Newhall devoted the largest section of the book, "Dynamics," to describing the earth's complex natural and ecological cycles. The section derives from several panels of the exhibition including Panel Five and Panel Seven. The chapter opens with Adams's

\footnotetext{
59 Thomas Robertson, "This Is the American Earth: American Empire, the Cold War, and American Environmentalism," Diplomatic History 32, no. 4 (September 2008): 571, doi: 10.1111/j.1467-7709.2008.007 13.x.

${ }^{60}$ Hammond, Divine Performance, 118.
} 
Pasture, Sonoma County, California, an image where man-made structures blend into the landscape, as evidence that it is possible to "shape a civilization in harmony with the earth" (p. 48-49). The next double-page spread directly follows the image selection and text from Panel Five of the exhibition, in which Newhall explained the process of the water cycle. Her text on the subsequent pages has a similar message as Panel Seven of the exhibition, although she made minor changes. Newhall's text describes nature's incredible ability for adaptation and variation alongside Adams's Refugio Beach, California and Brett Weston's White Sands, New Mexico (p. 52-53). Refugio Beach replaced Weston's Southern Swamp from Panel Seven of the exhibition, but it essentially carries a similar meaning and mood as an abstract image of water, which continuously changes form (p. 52). As in the exhibition, Weston's White Sands, New Mexico implies the constant evolution and competition between plants, "pressing with delicate filaments against harsh and hostile barriers" (p. 53).

Continuing on the theme of adaptation in the next double-page spread, Newhall's text discusses the ability for these natural forms to flourish in extreme habitats ranging from oceanic depths to mountainous heights. Philip Hyde's Aspens, Sierra Nevada and Eliot Porter's Tern in Flight, Maine depict the versatility of animal and plant species to survive in arduous climates (p. 54-55). Cedric Wright's Junipers at Timberline facing Newborn Fawn remind the reader that all natural species, whether plant or animal, must compete for survival (p. 56-57). In the half page above Newborn Fawn, Newhall selected lines from Robinson Jeffers's poem “The Bloody Sire," turning Newborn Fawn into an image of nature's fragility (p. 57). Influenced by the arrangement of image and text in Panel Seven of the exhibition, with its portrayal of the forces of life and death and emphasis on the role of soil in the process of nature's renewal, Newhall again displayed Edward Weston's Cypresses and Stonecrop, Point Lobos, California (p. 59).

As she had in Panel Seven, in which she expressed an ecocentric viewpoint, Newhall argued that nature holds wisdom and power beyond human knowledge. She wrote, "Still beyond our grasp shimmer the ultimate truths. / Unless we master these, how shall we learn-not to die-but to live?" (p. 60). Occupying a full-page facing the text, Adams's Burnt Stump and New Grass, Sierra Nevada complements these lines of text, as evidence of nature's power of self-renewal. However, when Newhall posed the same question in her exhibition text for Panel Six, she followed with a series of practical ways to maximize the use of forests. In contrast, here she maintained an ecocentric viewpoint, in which humans have much to learn from nature's cycles. Additionally, this 
specific line in Newhall's text strongly echoes Emerson, who wrote, "Let us interrogate the great apparition that shines so peacefully around us. Let us inquire to what end is nature?"61 Like in the exhibition, on the next double-page spread Newhall reproduced three photographs and text from the end of Panel Seven, which described the wilderness as an interconnected living system that humans have yet to understand (p. 62-63).

Up to this point in "Dynamics," Newhall conveyed the ecological value of the wilderness. However, Newhall adopted a more anthropocentric viewpoint in the chapter's final three double-page spreads, in which she proposed ways that humans can sustainably use natural resources. With a half-page image of Adams's Irrigation, Salinas Valley, California facing his Shasta Dam, California, as well as with the next double-page spread presenting Adams's San Francisco from TV Hill, Newhall promoted planned cities, clean air, and the well-researched use of natural resources (p. 66-69). Unlike Panel Five of the exhibition, Newhall does not differentiate between good dams and bad dams in the book, only briefly stating that they are essential to human survival. The chapter ends on Edward Weston's Grains Beside the Pacific California, a serene image that gives the impression that modern society can learn to use natural resources with little impact on nature's balance.

\section{The Crucial Resource}

With fourteen images in the final section, Newhall returned to her celebration of the intangible benefits that nature can offer mankind. The chapter primarily borrowed its theme and text from Panel Ten, sharing its opening statement, "Of all resources, the most crucial is Man's spirit." Yet, unlike the exhibition, the chapter begins with a subdued tone with Newhall's text describing humanity's spiritual deprivation. In support of her text, Pirkle Jones's Wave and Sun, the Pacific facing Gerry Sharpe's Boy and Horns, give the impression of darkness and a depressed human state (p. 73).

On the next double-page spread, Adams's Tenaya Lake, Yosemite, printed across the gutter, becomes the ultimate answer to man's need for creative and spiritual inspiration alongside Newhall's text, which contends that elements of the natural world are "sources of Man's spirit [and] symbols of his goals" (p. 74-75). Throughout the remainder of the section, Newhall borrowed the argument and

${ }^{61}$ Ralph Waldo Emerson, Nature, rev. ed. by Kenneth Walter Cameron (1836; repr. New York: Scholars' Facsimiles and Prints, 1940), 6. 
visual form from Panels Ten and Thirteen of the exhibition, presenting a variety of images to convey the diversity and thrilling beauty of the American landscape which mankind should experience "with only a few companions." As she had in the exhibition, Newhall portrays the wilderness as a safe and inviting environment to explore, choosing to present Adams's Child in Mountain Meadow (p. 80). At the same time, the book shows a more exhilarating side of nature with two newly selected images by Adams, Yosemite Falls and Stump and Mist, Northern Cascades, Washington (p. 82-83). In Hammond's interpretation, Stump and Mist is evidence of the complete cycle of life as it depicts the youthful sapling, mature pine, and old stump. ${ }^{62}$ It is in this way that Newhall utilizes the image to represent "the whole of life strange, miraculous, living, dying, changing" (p. 83). The elevated emotion in the sequence builds to a double-page spread of Adams's Winter Storm, Yosemite, representing the "immortal challenges" that the wilderness offers to those seeking adventure (p. 84-85).

This sequence abruptly turns to quiet with the image of a still lake in Adams's Sunrise, Mount McKinley, occupying most of the double-page spread. Here, Newhall's text describes the wilderness as a refuge for individual thought and self-renewal, especially in humanity's darkest moments when "all learning [is] lost" and "all music [is] stilled" (p. 86-87). The book's final double-page spread displays Adams's Aspens, New Mexico, an image of a young aspen tree that appears to be emanating light. The high contrast of the image causes the single aspen tree to stand out from its dark surroundings as a unique and individual element in nature. While the final lines of Newhall's text address the whole of humanity, reading, "Tenderly now let all men turn to the earth," the photograph of the aspen tree appeals to the individual alone, as an intimate plea to cherish the unique beauty of the wilderness.

\subsection{CONSERVATION PERSPECTIVES}

The content of the book This Is the American Earth largely reflected Adams's and Brower's purist standpoint on nature conservation, and the book did not have the support of the majority of the Sierra Club. Looking back in 1963, Brower could not forget that it was published "over the almost complete objection of the then Editorial Board."63 Both Adams and Brower represented a more militant view of national parks protection and unlike the rest of the Sierra Club, they had a deep

${ }^{62}$ Hammond, Divine Performance, 123.

${ }^{63}$ Brower to Publications Committee, 9 October 1963, Sierra Club Office of the Executive Director Records, carton 20, folder 7, Bancroft Library. 
emotional attachment to the wilderness that led them to deplore any form of human activity in the parks, from tourism to resource development. As an example, while the Sierra Club frequently promoted resort vacations in the parks, in 1938 Brower adamantly opposed the construction of resorts in an article in the Sierra Club Bulletin. ${ }^{64}$ Similarly, writing for the Bulletin in 1932, Adams stated, "we should bear in mind that the mountains are more to us than a mere proving ground of strength and alert skill. Rock climbing should be considered a thrilling means to a more important end."65 Theirs was a viewpoint that closely aligned with Muir's ideals, and several areas of the book TITAE reflected Muir's philosophy that nature should be preserved for its spiritual and ecological value.

While Newhall conducted research for the book in 1958, David Brower became considerably involved in editing her manuscript and suggesting books for her to read. ${ }^{66}$ Newhall began to collaborate with Brower on "what we agreed was missing in the original show." 67 In particular, Brower played a large role in the book's inclusion of the overpopulation issue, which was not part of the original exhibition. While drafting the book, Newhall wrote to Adams that she and Brower "decided to add the population problem ... and to keep all our eyes peeled for some good bad photographs - the devastations etc."68 Newhall's and Brower's approach to overpopulation was unsympathetic to the human race, and by taking this stance, Newhall, Adams, and the Sierra Club risked appearing to be anti-humanist. In the newly added section entitled "The Mathematics of Survival" Newhall and Brower characterized the archetypal Man as "a looming devourer, / disproportionate to earth, threatening with his multitudes all life" (p. 58). Additionally, as Newhall's text argued, the people in Berko's photograph Bathers on the River Ganges not only exhaust the supply of resources but are an immoral race that will "exploit and murder weaker nations" (p. 4244). Significantly, Newhall and Brower did not implicate American citizens in their discussion of overpopulation, although Newhall does criticize the development of American cities. By contrast, the exhibition TITAE did not promote such an extreme criticism of the human race, especially not with exclusive reference to India. Where the exhibition briefly touched upon the issue of population

\footnotetext{
${ }^{64}$ David Brower, "Beyond the Skiways," Sierra Club Bulletin 23 (April 1938): 40-45, quoted in Michael P. Cohen, The History of the Sierra Club, 1892-1970 (San Francisco: Sierra Club, 1988), 81.

${ }^{65}$ Ansel Adams, “Retrospect Nineteen-Thirty-One," Sierra Club Bulletin 17 (February 1932): 7, quoted in Cohen, History of the Sierra Club, 81.

66 Brower to NN, 29 November 1958, Sierra Club Office of the Executive Director Records, carton 21, folder 42, Bancroft Library. Brower suggested Newhall read two books by John Kenneth Galbraith, Perspectives in Conservation: Essays on America's Natural Resources, ed. Harry Jarrett (Baltimore: John Hopkins Press, 1958); The Affluent Society (Boston: Houghton Mifflin, 1958).

${ }^{67} \mathrm{NN}$ to Brower, 29 June 1958, NN at CCP.

${ }^{68} \mathrm{NN}$ to AA, 19 May 1958, AAA at CCP.
} 
increase in Panel Three, it was expressed as a positive historical fact rather than an anxiety. Newhall's text from Panel Three read, "From America poured such wealth and hope that populations began a rise unprecedented in history."

Unlike the exhibition, the book included many overtly negative depictions of humanity. Conveying a morally and spiritually deprived human race, these images included Jacob Riis's Bandits' Roost, Lower East Side; Gerry Sharpe's Boy and Horns; Werner Bischof's Famine, India; and Adams's Trailer Camp Children. Through these images, Newhall and Brower argued that severe negative social consequences will result from society's disconnect from nature. By contrast, in the exhibition, where Newhall displayed photographs depicting humans, they were neutral portraits of America's conservation leaders on Panel Four and positive images of children such as Barbara Morgan's Girl with Recorder on Panel Eleven, and Adams's Boy and Waterfall on Panel Fourteen. The single exception to this was Panel Two, which presented Bischof's photograph of starving people in Bihar, India. However, paired with the accompanying text, it was solely intended to illustrate the terrible effects of famine caused by poor methods of farming. Despite Brower's input and editorial control over Newhall's text for the book TITAE, Newhall did not incorporate many of his suggestions. For example, Newhall's final text for the book does not reflect Brower's comments on the TITAE manuscript that he sent to Newhall in 1959.69 Spaulding's biography on Adams provides further evidence of Newhall's artistic reign in the book, as he recalls how Brower, in an interview, reenacted the dramatic "No!" that Newhall produced whenever he made an editorial suggestion. ${ }^{70}$

The book also reflects some of the more extreme opinions held by Adams, such as his repulsion for the droves of tourists in Yosemite National Park, to which Sierra Club programming often contributed. During his first summer as the custodian of LeConte Lodge, he wrote:

The old Yosemite spirit has long past [sic] and the atmosphere of several years ago is no more. The crowds are of the cheapest and commonest cast and social doings supercede [sic] the Natural Attractions. The roads are like Market Street and Camp Curry like a city Hotel lobby. I am glad indeed to be in my position at the Lodge where I am away from all that noise and hurry, and the next time I come to the Valley, I [will] camp by myself near the river and get into the High Sierra as fast as I can for the floor of the Valley is one big parking station. ${ }^{71}$

69 David Brower to NN, 3 August 1959, NN at CCP.

70 Spaulding, Biography, 309.

${ }^{71}$ AA to Charles Adams, 2 June 1920, AAA at CCP, quoted in Rebecca Senf, "Ansel Adams's 'Practical Modernism': The Development of a Commercial Photographer, 1916-1936," (doctoral dissertation, Boston University, 2008), 44. 
Just four years earlier, Adams and his family could have counted themselves among these tourists on Adams's first summer holiday in Yosemite, but by 1920 Adams had grown into a serious hiker and yearned for the more remote and solitary experience of the wilderness that the park offered. ${ }^{72}$ Possibly influenced by Adams's perspective, in TITAE's third section, "The Machine and a New Ethic," Newhall delivered a lengthy criticism of tourist culture in the 1920s and 30s:

Even on holidays ... we jammed the highways, moved bumper to bumper, inch by inch, past suburbs, industries, junkyards, evil marshes, burning refuse, until, weary, desperate the day half gone, we turned off at the first shine of leaves or glint of water - and crashed through saplings, tore flowers and branches, threw trash, polluted streams. . . ${ }^{33}$

Adams also expressed his wish for the book to address the 1957 Tenaya Lake proposal, put forth by the National Park Service to increase the number of visitors in the parks. ${ }^{74}$ It was part of the NPS's initiative to make the parks more accessible by 1966, and their first project was to improve the Tioga Road in Yosemite National Park in order to allow commercial vehicles to pass easily from Owens Valley to the densely populated San Joaquim Valley. ${ }^{75}$ Although the plan was opposed by Adams, Brower, and Richard Leonard, the rest of the club did not want to fight against the federal agency. ${ }^{76}$ As Cohen's history of the club recounts, Adams felt so strongly about preserving the original road, as well as the meadows and lake in its immediate surroundings, that he submitted his resignation to the Sierra Club board, allowing him to make an individual statement of opposition to the NPS. ${ }^{77}$ However, Adams was not able to stop the proposal himself and the road was quickly constructed in 1958. Adams's letter asking Newhall to address Tenaya Lake in the book revealed that he was still deeply upset over this outcome. He wrote, "It is the prime example of what NOT to do! The NPS simply has to be cut down to size and to proper function!!!!!!!"78 In the end, Newhall chose not to address the construction of Tioga Road in the book, although she briefly condemned the construction of highways.

Newhall also chose to leave out the material from the three panels by Frann Spencer Reynolds, Richard Reynolds, and Ted Spencer. Although she first entertained the idea of making the illustrations into endpapers, she and Adams, as well as Brower and editorial board member August

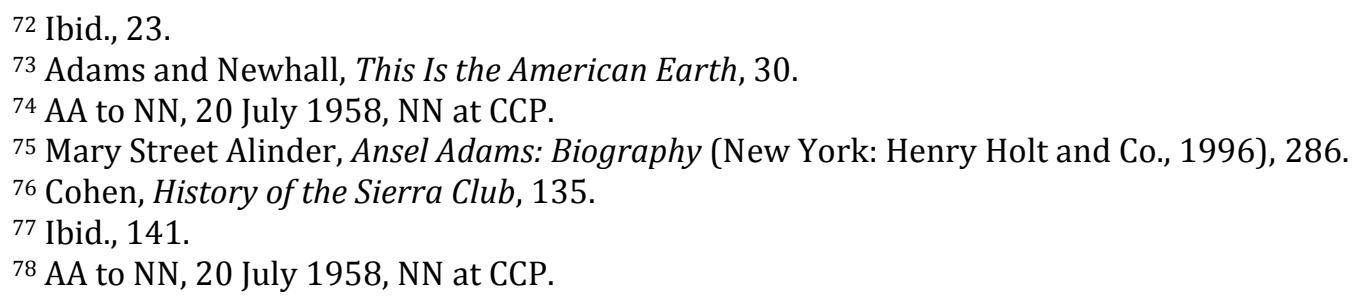


Frugé, remarked that the content was "an entirely different 'language."'79 In a later letter to Newhall Adams complained that the Spencers' approach to conservation was too "intellectual," in contrast to the emotional presentation desired by Adams, Newhall, and Brower. ${ }^{80}$

\subsection{DISTRIBUTION, SALES, AND RECEPTION}

The Sierra Club oversaw the book's distribution in thirteen western states including Alaska, Arizona, California, Colorado, Idaho, Hawaii, Montana, Nebraska, New Mexico, Oregon, Utah, Washington, and Wyoming. For the remainder of the national distribution, the Sierra Club enlisted the help of Alfred Knopf of Borzoi Books. ${ }^{81}$ However, with their conservation themed-message packaged into a high-quality photography book, Adams and Newhall wanted This Is the American Earth to be read not just by Sierra Club members and the general public, but also by people interested in photography. Beaumont Newhall sent copies of the book to his international network of film and photography people including the director of Photokina, Fritz Gruber; collectors and photo-historians Helmut and Alison Gernsheim; the director of an Amsterdam-based press agency and son of the famous photojournalist Erich Salomon, Peter Hunter; the editor of the Swiss magazine Camera, R. Martinez; Belgian filmmaker Henri Storck; German photographer Otto Steinert; the exhibitions manager and photography curator at the Victoria and Albert Museum, Charles Gibbs-Smith; and the co-curator at the Bibliothèque Nationale, Jean Prinet. ${ }^{82}$

Despite its high price, the book This Is the American Earth sold 7,500 copies—nearly its entire first print run — within seven months of its publication date and over the next few years, garnered acclaim from book clubs, the graphic arts community, and the photography scene. ${ }^{83}$ Among the people interested in photography, from collectors to camera club members, TITAE caused a wide range of reactions. Historian and photography collector Helmut Gernsheim, who frequently corresponded with Beaumont Newhall, generously reviewed the book TITAE in the London based

${ }^{79}$ AA to NN, 17 January 1958, AAA at CCP.

${ }^{80}$ AA to NN, 1 March 1958, AAA at CCP.

81 Brower to Sidney R. Jacobs at Alfred Knopf, 4 March 1960, Sierra Club Office of the Executive Director Records, carton 21, folder 42, Bancroft Library; Sidney R. Jacobs to Brower, 23 November 1960, Sierra Club Office of the Executive Director Records, carton 21, folder 42, Bancroft Library.

82 Elizabeth Lehman to Beaumont Newhall, 18 August 1960, Sierra Club Office of the Executive Director Records, carton 21, folder 42, Bancroft Library.

82 Brower to Publications Committee, 9 October 1963, Sierra Club Office of the Executive Director Records, carton 21, folder 42, Bancroft Library.

83 Of the 7,500 copies, 2000 were sold at a special prepublication offer. Brower to Sidney R. Jacobs, 21 July 1960, Sierra Club Office of the Executive Director Records, carton 21, folder 42, Bancroft Library. 
visual arts journal Motif. He opened with an acknowledgement of the particularly unfortunate state of American photobooks, in which the "standard for printing and design is on the whole even worse than here." 84 Then, he followed with a glowing review of TITAE, singling it out as a wonderful anomaly among its American counterparts. He praised the book's selection of photographs and goes "so far as to say that the photogravure reproductions are indistinguishable" from the originals. ${ }^{85}$ Given his relationship to the Newhalls, and his reliance on them for information on the history of photography as well as for their connections to American photography journals, it is unlikely that he would have written an unfavorable review. The George Eastman House journal Image included a review of TITAE written by Hugh Edwards, the curator of photography at the Art Institute of Chicago, who spoke generously of the high-quality reproductions, and perhaps as a subtle critique of Steichen's exhibitions at MoMA, commented that the book remains "free of the shallow, unrewarding horrors of togetherness." 86

As they had with the exhibition, Adams and Newhall used Aperture as a platform for publicity. Reviewing the book for Aperture, Minor White affirmed the book's aesthetic superiority, declaring that "the welding of visual and verbal experience has rarely been matched." He applauded the way "words and pictures are put to the only inevitable purpose that man knows - the preservation of his own means of life on earth, in order to cultivate his own soul." 87 White's review emphasized that TITAE delivered a significant message about nature as a source of creative and spiritual inspiration. However, TITAE was not equally popular in the camera club arena. U.S. Camera hailed Adams's photographs for their "sincerity of vision," but called the book "pretentious" and interpreted the large format as a sign of narcissism on the part of the photographer. ${ }^{88}$ With U.S. Camera's regular suggested reading list of inexpensive photography manuals catering to an audience of amateur and commercial photographers, the magazine criticized TITAE's high cost, writing that it "will go only to those people already devoted to the cause [of conservation] who are affluent enough to purchase it." 89

\footnotetext{
${ }^{84}$ Helmut Gernsheim, “Book Reviews: Photographic Images,” Motif 8 (1961): 98.

85 Ibid.

${ }^{86}$ Hugh Edwards, review of This Is the American Earth, by Ansel Adams and Nancy Newhall, Image 1, March 1960, 48.

${ }^{87}$ Minor White, review of This Is the American Earth, by Ansel Adams and Nancy Newhall, Aperture 7, no. 4 (1959):172.

${ }^{88}$ Ed Hannigan, ed., "New Books," review of This Is the American Earth, by Ansel Adams and Nancy Newhall, U.S. Camera, September 1960, 26.

${ }^{89}$ Ibid.
} 
Not surprisingly, in America the book found popularity among the conservation-minded and those who were already acquainted with the themes of the book. Secretary of the Interior Stuart L. Udall listed TITAE among his favorite books in an interview that year with the Vassar Club, while Supreme Court Justice William O. Douglas hailed it as "one of the great statements in the history of conservation." 90 A review in National Parks Magazine by co-founder of the Wilderness Society, Benton MacKaye, reveals that Adams's and Newhall's photography-writing was not lost among conservationists. MacKaye called TITAE an "emotional experience" and a "symphony of word and picture." 91 While it does not appear that the NPS reviewed the book in its quarterly publication, Brower did receive a personal letter from its editor, Herbert Evison, who remarked that the messages it conveyed "are not of the moment; in book or exhibit, what it has to say will be of importance still in the year 2,000 and probably much farther in the future than that."92

This Is the American Earth also received attention in popular media. Life magazine published a double-page spread titled "Serene Sermon in the Sierra" reproducing Adams's Sierra Nevada from Lone Pine, California - the first spread in TITAE's overture. ${ }^{93}$ A Sierra Club advertisement announced that the book received positive reviews from The New York Times, San Francisco Examiner, The Washington Star, Los Angeles Mirror, The Phoenix Gazette, and the Columbus Citizen Journal. ${ }^{94}$ In a particularly enthusiastic treatment of the book, the Rochester Democrat and Chronicle, the local paper that consistently reviewed the Newhalls at George Eastman House, produced a feature that presented six photographs from the book with accompanying articles over a period of six days. ${ }^{95}$ The newspapers and editorials focussed on the way TITAE gave artistic expression to a theme that was more likely to be expressed, but less effectively so, in the technical jargon of science and politics. They gave equal mention to the book's words and photographs, discussing them as a unified voice in presenting the wilderness case. Newhall's elevated style of prose-poetry was compared to the writings of William Shakespeare, Cotton Mather, and Walt Whitman.

\footnotetext{
90 William Hogan, “The Literate Cabinet Reveals Their Favorites," A Bookman's Notebook, The Victoria (TX) Advocate, n.d., Nancy Newhall Papers, box 242, folder 4, GRI.

91 Benton MacKaye, review of This Is the American Earth, by Ansel Adams and Nancy Newhall, National Parks Magazine, February 1960.

92 Herbert Evison to Brower, 29 October 1960, AAA at CCP.

93 "Serene Sermon in Sierra," Life, 28 November 1960, 10-11.

94 Sierra Club Bulletin 45, no. 3 (March 1960), Sierra Club Members Papers, Bancroft Library.

95 The last article in the feature was Jean Walrath, "Grandeur of the Earth," review of This Is the American Earth, by Ansel Adams and Nancy Newhall, Rochester Democrat and Chronicle, February 14, 1960. Nancy Newhall Papers, box 242, folder 4, GRI.
} 
The book won awards in various fields outside of photography. It won a place among the American Institute of Graphic Arts' "Fifty Books of the Year" in 1961 and earned a place in its annual book exhibition. ${ }^{96}$ TITAE was also selected among the 1960 list of "Notable Books of the Year" by the American Library Association, based on recommendations from thirty-six libraries across the United States. ${ }^{97}$ To compile its annual list, the association selected forty-six books that were "significant in content [and] readable in style, for the adult who is looking for contemporary material worthy of his reading time." 98

This Is the American Earth's selling success proved its popularity among a post-war American audience, and within three years, TITAE had sold 17,000 copies. ${ }^{99}$ TITAE's unique form, along with the lack of an established American photobook market, make it difficult to compare it to other photobooks of its time. However, it showed considerably greater success on the market than its contemporaries, with the exception of The Family of Man which sold an astounding 4 million copies.100 TITAE's strong sales were likely due to the accessibility of its subject matter. Even if it contained an element of negativity and criticism, the book's overall emotional message about the beauty of the American landscape and its images of breathtaking scenery could be appreciated by an average reader, and the book's serious argument about conservation would only help to broaden the readership to include intellectuals and environmental activists. To take one comparison, the English edition of Robert Frank's The Americans, published in the same month as TITAE, sold only 1,100 of its 2,600 copies before being withdrawn by its publisher within a year's time, in part due to reviews that criticized the book's anti-American sentiment and photograph quality. ${ }^{101}$ In addition, unlike TITAE, the format of Frank's book was small and bore no resemblance to the familiar large size and varied page layouts of picture magazines, and thus it would not be familiar to a readership outside of photographers and book collectors. As a closer comparison to TITAE in terms of its price and aesthetic, Richard Avedon's 1964 graphic photobook Nothing Personal, measuring eleven by fourteen inches with accompanying text by James Baldwin, was harshly criticized for its pretentious

\footnotetext{
${ }^{96}$ Brower to John L. Fasmore, 15 February 1960, Sierra Club Office of the Executive Director Records, carton 21, folder 42, Bancroft Library.

${ }_{97}$ Marion L. Simmons to Paul Tanner at the Democrat-Chronicle, 4 July 1961, Nancy Newhall Papers, box 242, folder 4 , GRI.

98 Ibid.

${ }^{99}$ Brower to Publications Committee, 9 October 1963, Sierra Club Office of the Executive Director Records, carton 20, folder 7, Bancroft Library.

${ }^{100}$ Sandeen, Picturing An Exhibition, 38.

101 David Harris, "The Americans at 50: A Review of the Exhibition and Related Publications of Looking In: Robert Frank's The Americans," Photography \& Culture 4, no. 1 (March 2011): 94, doi: http:// dx.doi.org/10.2752/17514521 1X12899905861555.
} 
large format in a scathing review from The New York Review of Books entitled "Everybody Knows My Name."102 Thus, it seems that TITAE managed to evade severe criticism by engaging with widely marketable American themes rather than simply standing as a book of art photographs. Its sales potential was undoubtedly a concern from the outset, as the high-priced photobook had not yet found a foothold in the American book market. Nevertheless, the outcome of TITAE seemed to prove, as Brower had said, that "art books by no means necessarily reach the converted," and that it could be appreciated by a wide range of consumers. ${ }^{103}$ The book later reached a larger audience through a less expensive paperback version by Ballantine Books released in 1968, and went out of print in the 1970s. ${ }^{104}$ A revised version was published by the Sierra Club in 1992.

102 Robert Brustein, review of Nothing Personal, by Richard Avedon, New York Review of Books 3, no. 9, December 17, 1964.

${ }^{103}$ Brower to NN, 29 November 1958, Sierra Club Office of the Executive Director Records, carton 21, folder 42, Bancroft Library.

${ }^{104}$ Featherstone, "A Collaboration," 63. 


\section{CHAPTER FOUR}

\section{IMPACT AND LEGACY}

The exhibition and book This Is the American Earth helped to redefine the purpose and activities of the Sierra Club throughout the 1960s. The book initiated a change in the club's campaign strategies, which became more direct and proactive, as the club embarked on an ambitious program in publishing conservation-themed photography books from 1960 to 1968. In addition, the exhibition This Is the American Earth inspired a continuation of several smaller conservation-themed exhibitions that were shown in Yosemite National Park and toured nationally. The project proved to be a defining moment in the club's history, and in the 1990s, the club reissued the book and sponsored a restaging of the exhibition.

The Sierra Club viewed the book as an immediate success because of its potential to influence legislation. During the book's development from 1957 to 1960, the Sierra Club was focussed on supporting the passage of the Wilderness Bill, which was first conceived by the Executive Secretary of the Wilderness Society Howard Zahniser at the Second Biennial Wilderness Conference in $1951 .{ }^{1}$ Then in 1956, Senator Hubert Humphrey presented a draft of the bill to the Senate. ${ }^{2}$ Eager for the bill to be passed, the Sierra Club's Trustees for Conservation sent a copy of TITAE to every member of Congress in January 1960 with an accompanying letter that read, "I hope that it will reinforce your conviction that America owes a great debt to its wilderness-a debt that can best be paid by saving the best of what is left in the short time that remains." 3 Although the Wilderness Act was not passed for another four years, the club's campaign efforts did not go unnoticed. In August 1960, Senator Moss quoted Newhall's text from TITAE in his address to Congress:

Mr. President, I rise to talk about our blessed land ... What Americans must have is a new realization of the necessity of preserving our resources. We must understand that money wisely spent on conservation yields direct returns in timber, forage, and other products.... Nancy Newhall, one of our poets, recently compiled some of her verse under the title "This Is the American Earth." In a particularly moving poem she had this to say: In the centuries to come / Always we must have water for dry land, / Rich earth beneath the plow / Pastures for flocks and herds ... Yet never can man live by bread alone.... Too few of us aware [sic] that to

\footnotetext{
${ }^{1}$ Sierra Club, “History: Sierra Club Timeline," http://www.sierraclub.org/history/timeline.aspx.

2 David Backes, $A$ Wilderness Within: The Life of Sigurd F. Olson (Minneapolis: University of Minnesota Press, 1997), 266. Hammond addresses the Wilderness Bill in further detail in Divine Performance, 127-28.

3 Anne Chamberlain to Mr. Sandström, 25 January 1960, Sierra Club Office of the Executive Director Records, BANC MSS 2002/230c, carton 21, folder 42, Bancroft Library.
} 
any beauty we must come as lovers, not destroyers; Come humbly, softly, to look, listen, / Learn to cherish and to shield. 4

Senator Moss drew upon Newhall's text to make the case for increased government funding for natural resource development. However, it should be noted that unlike the original standpoint of TITAE, he framed nature's value in terms of economic benefit. The conservationist Max McGraw also distributed the book in the industrial sector, targeting companies that specialized in commercial resource development. ${ }^{5}$

Significantly, TITAE marked a return to a kind of campaign strategy used by John Muir and Robert Underwood Johnson, who fought for Yosemite State Park to be expanded into a national park. ${ }^{6}$ Muir and Johnson highlighted the aesthetic value of the wilderness through "ornate descriptive prose, elaborate drawings, paintings, photographs by William Henry Jackson, and engravings, which Johnson distributed to Congress."7 In the decades following this campaign stunt, the Sierra Club primarily campaigned for wilderness protection through its recreation programs. It was not until almost fifty years later in 1936, that an equally extravagant argument was made by Adams, as part of a campaign for expanding the national parks into the Kings Canyon region, using his recently published Sierra Nevada: The John Muir Trail. It was an expensive large-format book containing reproductions of landscape photographs, the originals of which Adams presented at an NPS conference on the Kings Canyon Bill. Later, Adams sent the book to Secretary of the Interior Harold Ickes to further advocate for the protection of Kings Canyon.

The only other book project that approached TITAE in its intention was This Is Dinosaur: Echo Park Country and Its Magic Rivers by Brower, Wallace Stegner, and Martin Litton, published by Knopf in 1955 as part of a campaign to save Dinosaur National Monument in Echo Park. ${ }^{8}$ Yet Brower later acknowledged that it was truly This Is the American Earth that marked the beginning of conservation publishing. ${ }^{9}$ The book TITAE was a dramatic shift in the club's campaign strategies.

\footnotetext{
486 Cong. Rec., 106, no. 137 (August 19, 1960), statement of Sen. Frank E. Moss, Sierra Club Office of the Executive Director Records, carton 21, folder 42, Bancroft Library.

${ }^{5}$ Max McGraw received letters of thanks from several companies including the Automatic Electric Sales Corporation, Corning Glass, New Orleans Public Service, Ohio Brass Company, Wilbur B. Driver Company (Strip Mill), Dole Valve Company, Phillips Petroleum Company, Sangamo Electric Company, and others. Various correspondence, AG31:1:41, folder "Max McGraw 1960," AAA at CCP.

${ }^{6}$ Michael P. Cohen, The History of the Sierra Club, 1892-1970 (San Francisco: Sierra Club, 1988), 6.

7 Ibid, 7-8.

${ }^{8}$ Wallace Stegner, This Is Dinosaur: Echo Park Country and Its Magic Rivers (New York: Knopf, 1955).

9 Brower to Publications Committee, "The High Cost of Consensus," 9 October 1963, Sierra Club Office of the Executive Director Records, carton 20, folder 7, Bancroft Library.
} 
The club no longer relied solely on tourism to educate and convince the public to preserve America's natural resources. Through books, they could effectively disseminate the message of conservation in the intimate setting of a home, library, or workplace. As the promotional pamphlet for TITAE amiably stated, "To own this book, to know it, to display it, to give it - this in itself is conservation." 10

Inspired by the success of the book TITAE, the Sierra Club embarked on a rigorous conservation publishing program, directed by Brower and a Publications Committee, with nineteen volumes to follow in the Exhibit Format Series. The books ranged from general nature appreciation books to those with a regional focus that could be used to support specific campaigns. While Brower and the committee determined the subject matter of each book in the series, Adams continued to generate the momentum behind many of the book projects. For example, in 1963, in an effort to save the Grand Canyon region from being flooded as part of a dam proposal, Adams proposed a book on the area as well as a smaller, more easily distributable pamphlet.11 A year later, when the Sierra Club proposed a book on the Big Sur region on the central coast of California, they approached Adams, who was then sitting as a member of the board of trustees of the Foundation for Environmental Design. Speaking on behalf of the board, Adams stated that the proposed book related to areas of "deepest interest to the Foundation," and offered a generous revolving fund in support of the project. ${ }^{12}$ Although Adams consistently supported Brower's book proposals and the publishing program, after TITAE he was much less involved, as he had to return to commercial work and his individual practice. ${ }^{13}$ Newhall was also occupied with other projects, one of which was a collaboration with Adams in 1963 on a book commissioned by the University of California. ${ }^{14}$

${ }^{10}$ Sierra Club Office of the Executive Director Records, carton 21, folder 43, Bancroft Library.

${ }^{11}$ George Marshall to Publications Committee, 24 October 1963, Sierra Club Members Papers, carton 2, folder 26, Bancroft Library. The book contained poetry by Robinson Jeffers and was titled Not Man Apart. Many of the Sierra members expressed dissatisfaction over the book as they found its approach too "antihuman." There are copious amounts of correspondence revealing the ideological debates within the club over the book. In one of the more extreme criticisms, the feeling of the book was compared to the Nietzschean sentiment of 1930s Germany. George Marshall to Wallace Stegner, 23 December 1964, Sierra Club Members Papers, carton 2, folder 26, Bancroft Library.

12 AA to Sierra Club, 14 September 1964, Sierra Club Members Papers, BANC MSS 71/295c, carton 2, folder 26, Bancroft Library.

${ }^{13}$ Jonathan Spaulding, Ansel Adams and the American Landscape: A Biography (Berkeley: University of California Press, 1995), 335.

${ }^{14}$ Ibid; Newhall and Adams, Fiat Lux: The University of California (New York: McGraw Hill, 1967). 
The club, now faced with the decision of how best to divide its funds and market its objectives through printed materials, asked whether it should engage in general nature publishing with magazines and pamphlets or produce books with a clear conservation purpose. ${ }^{15}$ Their debates, recorded in the club's meeting minutes, indicate that TITAE triggered a large re-evaluation of the club's mission, leading them to new possibilities for communicating with a broad audience and confronting a wider range of conservation issues. Brower was won over by the success of TITAE, and was impressed by the even higher sales of the first color Exhibit Format Series book with photographs by Eliot Porter, In Wildness Is the Preservation of the World, produced at the suggestion of Newhall. ${ }^{16}$ However, certain members of the editorial board did not share Brower's enthusiasm for books; they wondered whether the high cost of these publications would be beneficial in the long run, or whether the club could increase its membership through more affordable means. ${ }^{17}$ It was a valid concern, since over a period of three years, from 1963 to 1966, the club's deficit had grown by over $\$ 100,000$, and by 1968 , the club's President reported on the club's serious financial situation that could impact its individual directors. ${ }^{18}$ Regardless of these financial concerns, by this year, Brower's campaign goals had grown to encompass global conservation issues. The final two volumes of the series were international in scope and focussed on the threatened wilderness of the Galapagos Islands in Ecuador. Brower did not always have the support of the club in these books and there were instances in which he spent club funds on producing books and publicity materials without the consent of the publications and executive committees. ${ }^{19}$ Eventually, the series ended in 1968.

Despite the continuous appearance of new Sierra Club books and the battles within the club over publishing, the book TITAE continued to be relevant. In 1968, the Sierra Club issued a more affordable paperback version priced at $\$ 3.95$ through Ballantine Books. ${ }^{20}$ The exhibition TITAE also

\footnotetext{
15 Minutes of the Publications Committee, 14 October 1963, Sierra Club Members Papers, carton 2, folder 27, Bancroft Library.

${ }^{16}$ Eliot Porter, "In Wildness is the Preservation of the World," Exhibit Format Series 4 (San Francisco: Sierra Club Books, 1962).

17 Spaulding, Biography, 333.

18 Ibid., 144.

19 Ibid., 345.

20 Joseph Haas, "Best of the Paperbacks: Sierra Club Books Nature Showcases," review of This Is the American Earth, by Ansel Adams and Nancy Newhall, Chicago Daily News, 16 November 1968. The paperback version was out of print by January 1970. AA to Philip Berry, 24 January 1970, Sierra Club Members Papers, carton 2, folder 25, Bancroft Library.
} 
had an extended life. ${ }^{21}$ It spurred a variety of smaller conservation-themed exhibitions, sponsored by the Sierra Club, and produced for the LeConte Lodge and for national circulation. Newhall did not have a hand in organizing these exhibitions, and it was essentially Adams who continuously reworked the original This Is the American Earth project over the next few years. In late 1960, Adams successfully proposed a new version of the exhibition TITAE that displayed photographs and pages from the book TITAE mounted to card supports. ${ }^{22}$ This new exhibition occupied sixteen panels and was circulated by the Smithsonian Institution to universities, libraries, and art institutions from April 1962 to October 1963.23 In addition, in August 1962, Adams announced the deteriorating state of the exhibition at LeConte Lodge and urged the club to reaffirm its presence at the lodge by mounting a new exhibition. ${ }^{24}$ The new exhibition was completed in 1963 and included photographs, texts, and book prints from all the Exhibit Format Series books that had been published thus far. ${ }^{25}$

On the occasion of the Sierra Club's $100^{\text {th }}$ anniversary in 1992, to coincide with its release of a revised edition of the book This Is the American Earth, the Sierra Club invited the independent curator David Featherstone, who previously worked at the Friends of Photography, to restage the exhibition This Is the American Earth. By this time Adams and Newhall had both died, and the market for Adams's photographs had been growing steadily since the 1970s. The Friends of Photography, a non-profit photography organization co-founded by Adams and a group of West Coast photographers in 1967, was now the principal commercial representative of Adams's work. ${ }^{26}$ The exhibition opened at The Friends of Photography and toured internationally, with sponsorship from the Kubota Corporation, an environmentally-conscious construction company in Japan. Acknowledging that the 1955 exhibition was vastly different from the 1960 book, Featherstone arranged the new version of the exhibition to reflect the structure, photograph selection, and text of the book TITAE. This iteration travelled to six venues after its opening in Carmel, including The American Museum of Natural History in New York, four venues in Japan, and a final stop in

21 The Smithsonian duplicate returned to the California Academy of Sciences on March 23, 1959 but was not further exhibited. Annemarie Henle Pope to NN, 5 February 1959, AAA at CCP.

${ }^{22}$ The original idea for an exhibition displaying mounted book pages was suggested to Adams by Herbert Evison at the National Park Service. AA to Brower, 13 November 1960. Sierra Club Office of the Executive Director Records, carton 21, folder 42, Bancroft Library.

${ }^{23}$ Annemarie Henle Pope to AA, 17 October 1963, AAA at CCP. Library.

${ }^{24}$ AA to Walter Starr, 23 August 1962, Sierra Club Members Papers, carton 2 folder 41, Bancroft

${ }^{25}$ AA to Brower, Gerry Sharpe, Dick Pitman, and Virginia Adams, 7 May 1963, Sierra Club Members Papers, carton 2, folder 41, Bancroft Library. The exhibition was organized with the help of Brower and Adams's assistant, Gerry Sharpe, as well as Dick Pitman who did the panel construction. Sharpe mounted the prints at Adams's home in Carmel.

${ }^{26}$ Spaulding, Biography, 352-54. 
Yosemite National Park. ${ }^{27}$ The exhibition not only revitalized national awareness for the Sierra Club, but was also excellent publicity for Adams's work.

${ }^{27}$ Collection of David Featherstone. 


\section{CONCLUSION}

For This Is the American Earth, Adams and Newhall reconciled fine art photography with the medium's capacity for mass communication. In an oral history interview conducted by the Bancroft Library at the University of California at Berkeley, Adams characterized This Is the American Earth as a "theme show," a type of exhibition, Adams explained, that uses "photography for expressing ideas." ${ }^{1}$ He continued to define the theme show by explaining its particular aesthetic:

They were fine prints, but of a type. You see, the really fine print - the exhibit print — which is in effect a work of art, should be taken care of and presented and handled as such. Now, when you make prints for big exhibits - theme show exhibits — especially ones that are mounted on panels, you just say, "Well, these have a different function."2

Significantly, Adams's comments on the theme show demonstrate that the photographs in This Is the American Earth served a dual purpose, both as fine prints and as illustrations to advance a theme and argument. Adams and Newhall strove to balance the two competing aims of delivering an important educational message on nature conservation for the Sierra Club while remaining loyal to their credo on art photography.

As this thesis has revealed, the function of the exhibition and book This Is the American Earth was a key consideration for Newhall, who poured her energies into researching conservation history and practice to determine the precise message to present to the public in photographs and words. Rather than choosing a single perspective, Newhall organized the exhibition and book to express the diversity of opinions she encountered in her research, reflecting the plurality of America's conservation movement during the 1950s. As the primary stakeholder in the project, the Sierra Club viewed the purpose of TITAE in the context of regional activism, and it employed the exhibition and book as campaign tools to further its political agenda and increase its membership during the decade when the club was rapidly expanding.

A large portion of this thesis has brought to light the ways in which the exhibition and book engendered different philosophies and concerns about the natural environment from 1954 to 1960. In retrospect, Brower wrote that the exhibition TITAE embodied many ideas that were "later to be renamed environmentalism."3 For the book, Newhall and Brower expanded upon these ideas and

\footnotetext{
${ }^{1}$ Adams, Conversations, 540.

2 Ibid.

${ }^{3}$ David Brower, Work in Progress (Salt Lake City, Peregrine Smith Books, 1991), 12.
} 
incorporated new subject matter that would become, in the subsequent decade, the defining concerns of America's modern environmental movement. ${ }^{4}$ Despite differences between the exhibition and book, the latter ensured that a kernel of the exhibition, in its ephemeral form and as a major part of the Adams-Newhall collaboration, would not be altogether forgotten and would continue to reach an audience.

Newhall believed that the book This Is the American Earth had pioneered the way for a thriving market for photobooks made by art photographers. In her posthumously published essay "Photography Is my Passion," Newhall insisted that it was Adams's photographically-illustrated books from the late 1940s that initiated the "boom in fine books by and about photographers," and she insisted that she and Adams "touched off a further extension of the field when we did This Is the American Earth." ${ }^{5}$ Certainly, with historical perspective and a consideration of the limited scholarship on TITAE, it is evident that it has not significantly defined the market for American photobooks. However, Newhall's genuine conviction about the far-reaching impact of TITAE reveals that she approached the project not simply as a volunteer effort for the Sierra Club, but as a project that would have a greater impact on the acceptance of photography as a fine art with a defined market. Through TITAE, she continued the tradition of Stieglitz in her own form of expression that united images and words.

With the burgeoning market for photography and photobooks following the 1970s, the original social and political function of the book TITAE has largely been replaced by aesthetic and economic value. Undeniably, Newhall and Adams had wanted this kind of recognition for TITAE in the first place. However, there were considerable obstacles. Firstly, TITAE emerged during an era when photography was not yet widely appreciated as a fine art. Photography was primarily experienced through the illustrated press, and was almost exclusively perceived as a form of social communication. Secondly, with MoMA as one of the few art museums exhibiting photography during this time, and with the lack of such an influential institution on the West Coast, Adams and Newhall had limited choices in reaching a large audience with their exhibitions of photography. Thus, opportunistically, Adams viewed the LeConte Lodge as a space to display fine photography to the public. Moreover, through the exhibition's tour under the Smithsonian and USIA, Adams and Newhall were able to bring TITAE to a wider public and spread their ideal vision of America to the

\footnotetext{
${ }^{4}$ David Brower, Work in Progress, 12.

${ }^{5}$ Nancy Newhall, "Photography Is My Passion," in From Adams to Stieglitz: Pioneers of Modern Photography (New York: Aperture Foundation, 1989), 158.
} 
world. It was their deep wish for the exhibition This Is the American Earth to receive wide acclaim that exacerbated Adams's and Newhall's contempt for The Family of Man at MoMA, which has made an indelible mark on the history of photography, as was then predicted. The lack of attention This IS the American Earth received in its time and in the history of photography was largely a symptom of inadequate institutional support for photography in art museums across America and the widespread view of photography as popular art without significant economic value.

In this thesis' re-examination of the roots of TITAE, beginning with the exhibition and its subsequent evolution to book form, the project emerges as a significant example of how Adams and Newhall actively sought out and sustained projects that enabled them to advance their fight for the acceptance of photography as fine art. From Adams's modest proposal to save and refurbish the LeConte Lodge, This Is the American Earth transformed the Sierra Club and became an important creative outlet for Adams and Newhall, providing them with an opportunity to meld their philosophies on art and photography with their views of American society and the American landscape. 


\section{APPENDIX A}

This Is the American Earth Exhibition: Photograph Sources

The exhibition This Is the American Earth presented photographs from a variety of individual and institutional sources. Although not all of the following contributors were credited in the exhibition, these were the photographers that Newhall included in the exhibition as well as the sources she contacted to obtain negatives and prints: ${ }^{1}$

\section{Collectors and Institutions}

Alfred Knopf, American Trust Co., Francis P. Farquhar, George Eastman House, Farm Security Administration, Lick Observatory, Life magazine, Look magazine, Magnum Photos, National Park Service, Ralph Anderson, Samuel Chamberlain, Sierra Club, Soil Conservation Service, U.S. Forest Service, and U.S. National Archives.

\section{Photographers}

Werner Bischof, Margaret Bourke-White, Harold Bradley, Henri Cartier-Bresson, David Brower, Alexander Gardner, William Garnett, Tomar Jacob Hileman, Philip Hyde, William Henry Jackson, Joseph N. Le Conte, Barbara Morgan, Herman Postlethwaite, Eliot Porter, Arthur Rothstein, James

Robertson, A. J. Russell, Bradford Washburn, Carleton Watkins, Brett Weston, Edward Weston, and Cedric Wright.

${ }^{1}$ Various correspondence from Newhall, folder “TITAE 1955, Early Correspondence," Jan-May 1955, AAA at CCP; Nancy Newhall, Mr. Baillie, and Adams, "This Is the American Earth: List of Photographs," 8 August 1956, AAA at CCP. 


\section{APPENDIX B}

This Is the American Earth Exhibition and Book: Literary Sources

The following is a list of literary sources that Newhall made selections from and may have consulted in composing the text for the exhibition and book This Is the American Earth. The list corresponds to sources the author has referenced in the footnotes of the thesis and is by no means comprehensive. The author has compiled bibliographic information from online databases including WorldCat, Hathi Digital Trust Library, and Google Books.

"Additional Sources" are sources that the author consulted to investigate Newhall's use and interpretation of the original texts. Sources cited in this appendix are not included in the Bibliography.

\section{Newhall's Sources}

Alighieri, Dante. Divine Comedy. Vol. 1 Inferno.

Bradford, William. Of Plymouth Plantation. 1856. Revised edition by Samuel Eliot Morison. New York: Alfred Knopf, 1952.

Emerson, Ralph Waldo. "Prospects." In Nature. 1836. Revised edition by Kenneth Walter Cameron. New York: Scholars' Facsimiles and Prints, 1940.

Galbraith, John Kenneth. The Affluent Society. Boston: Houghton Mifflin, 1958.

— Perspectives in Conservation: Essays on America's Natural Resources, edited by Harry Jarrett. Baltimore: John Hopkins Press, 1958.

Leopold, Aldo. A Sand County Almanac and Sketches Here and There. New York: Oxford University Press, 1949.

Marsh, George. Man and Nature. Cambridge: Belknap Press, 1864.

Milton, John. Paradise Lost. Book 1.

Plato. Dialogues: Critias.

Powell, John Wesley. "Report on the Lands of the Arid Region of the United States." U.S. Geographical and Geological Survey, 1979. https://archive.org/details/reportonlandsofa 00geog. 
Thoreau, Henry David. “Chesuncook.” The Atlantic Monthly 2, no. 8 (June 1858).

Thoreau, Henry David. Walden. Volume I and II. Boston; New York: Houghton Mifflin, 1892.

Whitman, Walt. Leaves of Grass. Brooklyn, New York, 1855.

Williams, Roger. Bloudy Tenent of Persecution For Cause of Conscience Discussed and Mr. Cotton's Letter Examined and Answered. 1644. Revised edition by Edward Bean Underhill. London, 1848.

Wilson's, John A, trans. The Admonitions of Ipuwer. In Ancient Near Eastern Texts Relating to the Old Testament, edited by James B. Pritchard. $2^{\text {nd }}$ ed. Princeton: Princeton University Press, 1955.

Wise, John. Vindication of the Government of New England Churches. Boston, 1717.

\section{Additional Sources}

Hassan, Fekri A. "Nile Floods and Political Disorder in Early Egypt." In Third Millenium B.C. Climate Change and Old World Collapse NATO ASI Series Volume 49. Berlin: Springer Berlin Heidelberg, 1997. doi: 10.1007/978-3-642-60616-8_1.

Marks, Robert B. China: Its Environment and History. New York: Rowman and Littlefield, 2011.

Pinchot, Gifford. The Fight For Conservation. New York: Doubleday, Page, and Co., 1910.

Shaw, Norman. Chinese Forest Trees and Timber Supply. London: T. Fisher Unwin, 1914. 


\section{APPENDIX C}

This Is the American Earth Exhibition Itinerary

It has been possible to piece together an approximate itinerary for the exhibition's national and international touring venues through fragments of correspondence from the Ansel Adams Archive at the Center for Creative Photography and the meticulous record-keeping of the Smithsonian Institution Traveling Exhibition Service now preserved at the Smithsonian Institution Archives. ${ }^{2}$ While the following itinerary may not be entirely accurate since the Smithsonian's document listed the "Available Dates" for each exhibition venue and was certainly subject to revisions, it gives an overall idea of the types of venues in which This Is the American Earth would have been seen.

\section{Date} Sierra Club Tour Venue

\section{5}

Fall 1955; exact date Stanford University Library, Stanford, California unknown

\section{Smithsonian Institution Tour Venues}

\section{6}

April 1-June 30

August 1-September 16

October 5-26

December 12-January 3

1957

January 17-February 10

February 24-March 17
Museum of Science, Boston, Massachusetts

Rochester Museum Association, Rochester, New York

Lenscraft Studios, New York City

University of Illinois, Architecture Building, Urbana, Illinois
University of South Carolina, Russell House, Columbia, South Carolina

Michigan State University, Art Department, East Lansing, Michigan

${ }^{2}$ Undated document, "This Is the American Earth: Itinerary," Smithsonian Institution Traveling Exhibition Service, collection 290, box 58, folder 11, Smithsonian Institution Archives. 
April 1-22

May 5-26

1958

\section{9} unknown

February 21-Mar 1

March 14-22

March 23

February; exact date
Cranbrook Institute of Science, Bloomfield Hills, Michigan

New York State Museum, State Education Building, Albany, New York

Slater Memorial Museum, Norwich Free Academy, Norwich, Connecticut ${ }^{3}$

Other tour venues unknown
Idaho Historical Society, Boise, Idaho ${ }^{4}$

Des Moines, Iowa ${ }^{5}$

Chicago Horticultural Society at the Chicago World Flower Show, Chicago, Illinois ${ }^{6}$

Return to the California Academy of Sciences, San Francisco, California ${ }^{7}$

\title{
USIA Tour Venues
}

1957

\author{
Photokina, Cologne, Germany ${ }^{8}$ \\ Baghdad, Iraq ${ }^{9}$ \\ Belgrade, Yugoslavia ${ }^{10}$ \\ Tokyo, Japan ${ }^{11}$
}

${ }^{3}$ Slater Memorial Museum at the Norwich Free Academy of Connecticut to Annemarie Henle Pope, 5 February 1958, NN at CCP.

${ }^{4}$ Annemarie Henle Pope to H.J. Swinney at the Idaho Historical Society, 5 February 1959, AAA at CCP.

${ }^{5}$ Annemarie Henle Pope to NN, 5 February 1959, AAA at CCP.

${ }^{6}$ Ibid.

7 Ibid.

${ }^{8}$ Annemarie Henle Pope to Thomas Beggs, "New USIA Contract," 12 July 1956, Smithsonian Institution Archives.

${ }^{9}$ Joseph Nebesky at the USIA Exhibits Division Information Center Service to AA, 29 August 1957, AAA at CCP. Also see Annemarie Henle Pope to NN, 3 September 1957, NN at CCP.

${ }^{10}$ Annemarie Henle Pope to NN, 3 September 1957, NN at CCP.

${ }^{11}$ Eugene A. Schnell at the USIA Exhibits Division Information Center Service to Annemarie Henle Pope, 12 July 1957, AAA at CCP. 


\section{APPENDIX D}

\section{This Is the American Earth Exhibition Checklist}

This checklist has been compiled by the author as a visual aid for understanding the content and sequence of the exhibition. The order of the panels reflects the sequence of the exhibition at LeConte Lodge.

The order of the photographs, and their accompanying textual information, is primarily based on a 1956 typed document entitled “This Is the American Earth: List of Photographs," which appears to have been the documentation that accompanied the USIA's copies of the exhibition. ${ }^{12}$ This list produced a slightly different panel sequence, yet content and ordering of photographs within each panel remained the same. The 1956 document contains the photographs' original titles, negative numbers, and creator name, as well as the original photograph source.

In some instances, the author has deemed it useful to provide a contemporary published title, according to current printed and online sources. Some dates have been transcribed from the 1956 "List of Photographs," and others have been further researched.

Reference images may not accurately render the original printing of the photographs by Adams and his assistant Pirkle Jones.

\section{Panel 1}

1.

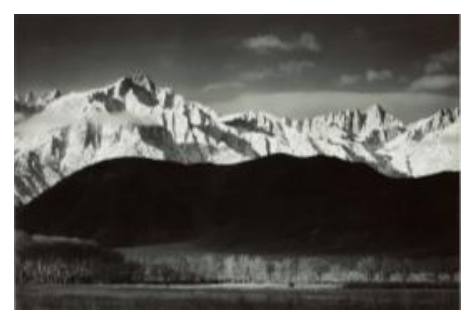

Adams, Ansel (American, 1902-1984)

Sierra Nevada from Lone Pine

[Published title: Winter Sunrise, Sierra Nevada, from Lone Pine, California]

Gelatin silver print

1944

Image courtesy of George Eastman House, 1967:0123:0024,

(C) Ansel Adams Trust

\footnotetext{
12 Nancy Newhall, Mr. Baillie, and Adams, "This Is the American Earth: List of Photographs," 8 August 1956, AAA at CCP.
} 
2.

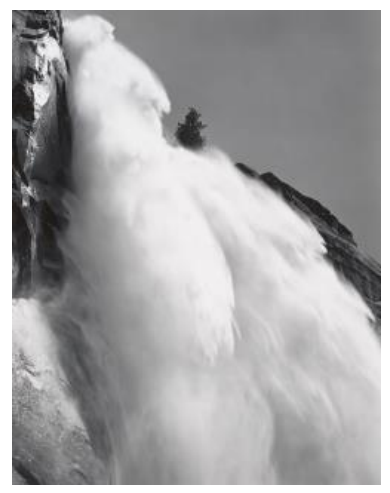

3.

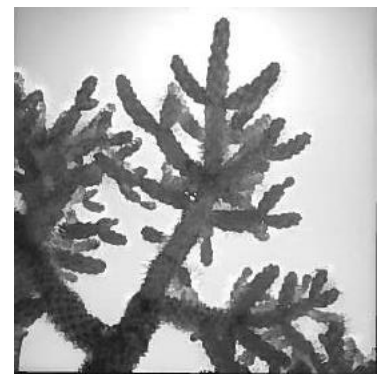

4.

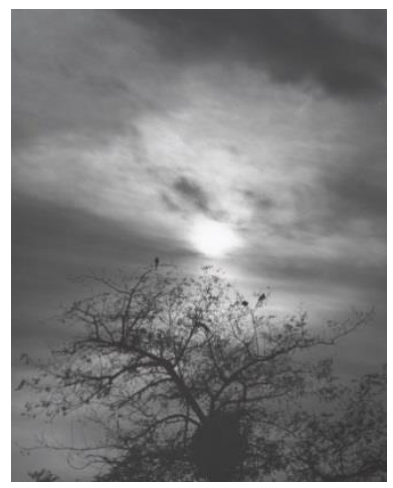

Adams, Ansel (American, 1902-1984)

Nevada Fall, Yosemite National Park 1946

Gelatin silver print

Image courtesy of the Center for Creative Photography, (C) Ansel Adams Trust
Adams, Ansel (American, 1902-1984)

Cholla, Noon, Organ Pipe National Monument [Published title: Detail, Cholla, Organ Pipe National Monument, Arizona]

1954

Gelatin silver print

Image courtesy of the Center for Creative Photography, (C) Ansel Adams Trust

Adams, Ansel (American, 1902-1984)

Midnight Sun, Glacier Bay National Monument [Published title: Midnight Sun, Glacier Bay National Park, Alaska]

n.d.

Gelatin silver print

Image courtesy of the Center for Creative Photography, (C) Ansel Adams Trust 
5.

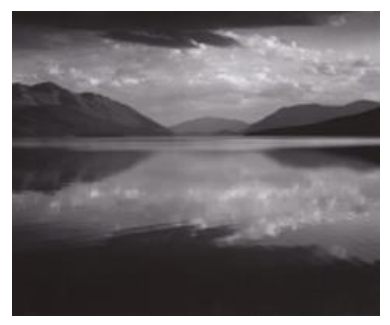

6.

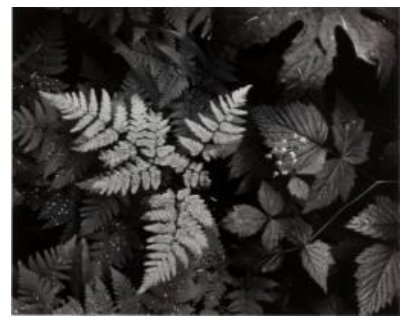

\section{Panel 2}

1.

No image available

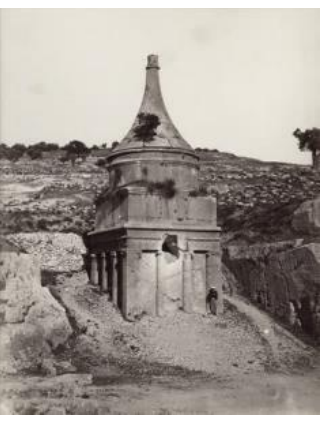

Adams, Ansel (American, 1902-1984)

Lake McDonald, Evening, Glacier National Monument [Montana]

1942

Gelatin silver print

Image courtesy of the Center for Creative Photography, (C) Ansel Adams Trust

Adams, Ansel (American, 1902-1984)

Fern and Leaves, Dew, Mount Rainier National Monument [Published title: Leaves, Mount Rainier National Park, Washington]

ca. 1942

Gelatin silver print

Image courtesy of George Eastman House, 1972:0065:0068, (C) Ansel Adams Trust

Unidentified Photographer

Halley's Comet

1910

Gelatin silver print

Original photograph courtesy of the Lick Observatory

Unidentified photographer

Tomb of Absalom, Palestine

ca. 1867

Gelatin silver print from an albumen silver print Original photograph courtesy of George Eastman House 
3.

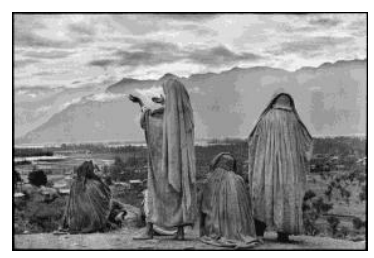

4.

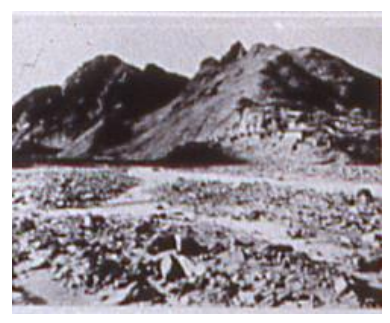

5.

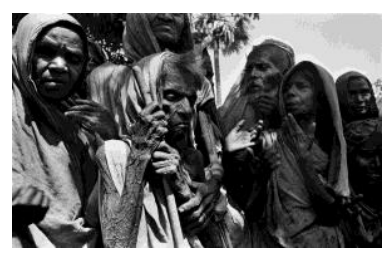

6.

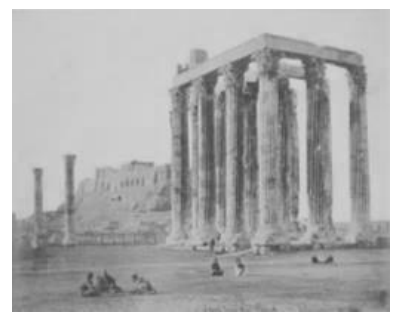

Cartier-Bresson, Henri (French, 1908-2004)

Mohammedan Women Praying, Sunrise, Himalayas

[Published title: INDIA. Kashmir. Srinagar. Muslim women on the slopes of Hari Parbal Hill, praying toward the sun rising behind the Himalayas.]

1948

Gelatin silver print

Original photograph courtesy of Magnum

Image courtesy of Magnum Photos

Unidentified Photographer

Shanxi Province, China

1903

Gelatin silver print

Original photograph courtesy of the U.S. Forest Service

Bischof, Werner (Swiss, 1916-1954)

Famine, India

[Published title: Bihar province. Dighiar. Starving Women.] From the series Hunger in Bihar

1951

Gelatin silver print

Original photograph courtesy of Magnum

Image courtesy of Magnum Photos

Robertson, James (British, 1813-1888)

The Acropolis

[Descriptive title: Olympian Zeus Temple and Acropolis, Athens.]

ca. 1854

Gelatin silver print from a salted paper print

Original photograph courtesy of George Eastman House

Image courtesy of George Eastman House, 1979:0001:0006 


\section{Panel 3}

1.

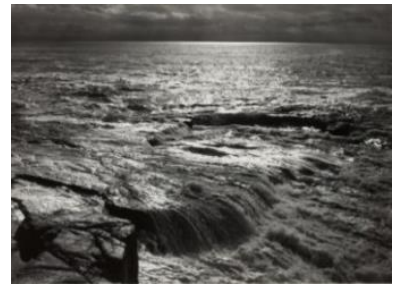

2.

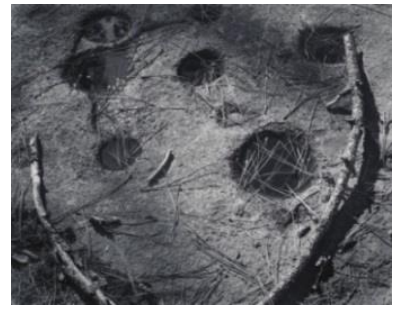

3.

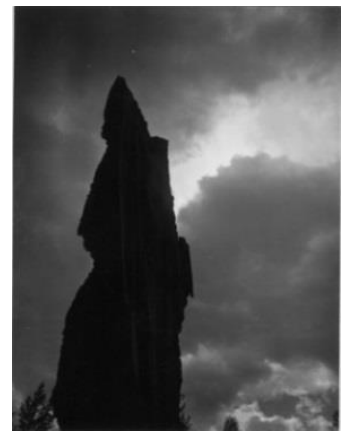

Adams, Ansel (American, 1902-1984)

The Atlantic, Clearing Storm, Acadia National Park [Published title: The Atlantic, Schoodic Point, Acadia National Park, Maine]

Gelatin silver print 1949

Image courtesy of George Eastman House, 1981:1017:0014, (C) Ansel Adams Trust

Adams, Ansel (American, 1902-1984)

Indian Mortar Holes, Yosemite National Park 1947

Gelatin silver print

Image courtesy of the Center for Creative Photography, (C) Ansel Adams Trust

Wright, Cedric (American, 1889-1959)

Stump in Thunderstorm, Sierra Nevada

n.d.

Gelatin silver print

Image courtesy of the Colby Memorial Library, Sierra Club 
4.

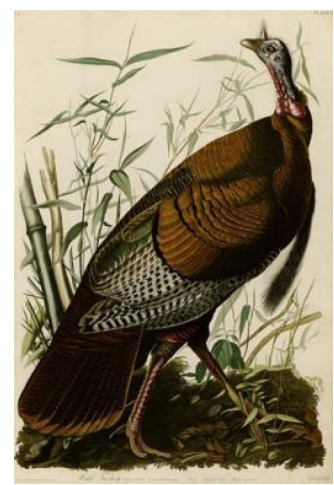

5.

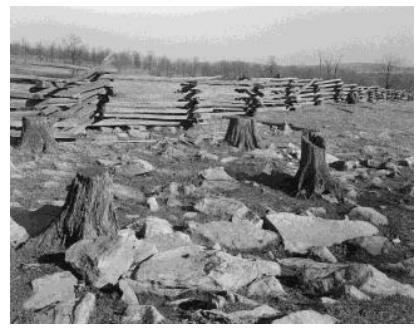

6.

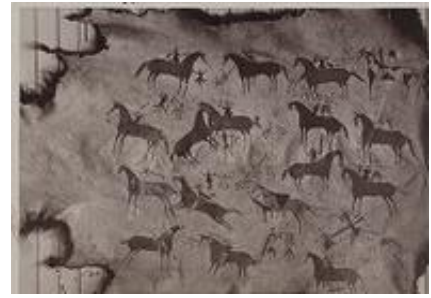

Audubon, John James (French American, 1785-1851)

Wild Turkey

Plate 1 from The Birds of America folio

1827-1839

Lithograph

Original print purchased for the exhibition
Rothstein, Arthur (American, 1915-1985)

Stumps and Rail Fence, Maryland

[Descriptive title: Rail fence and cut-over land. Garrett County, Maryland]

1937, Dec.

Gelatin silver print

Original photograph courtesy of the Farm Security

Administration

Image courtesy of the Library of Congress Online Collection

Jackson, William Henry (American, 1843-1942)

\section{Painting on Buffalo Robe}

[Descriptive title: Pawnee decorative painting on buffaloskin]

1868

Gelatin silver print from an albumen silver print Original photograph courtesy of Francis P. Farquhar

Image courtesy of Princeton Library Online Collection 
7.

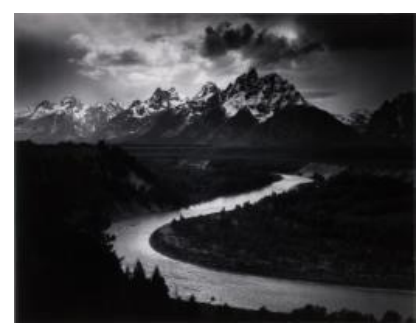

8.

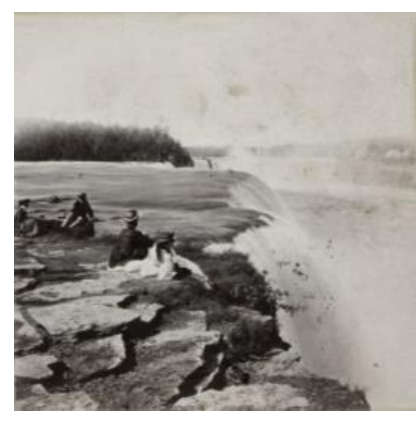

9.

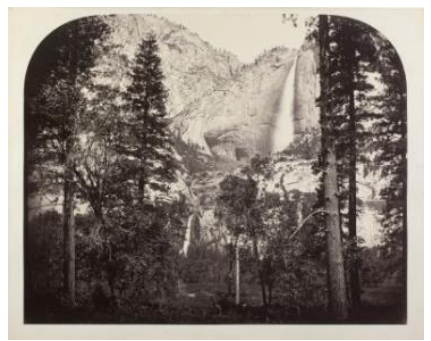

Adams, Ansel (American, 1902-1984)

Teton Range from Snake River

[Published title: The Tetons and the Snake River, Grand Teton National Park, Wyoming]

1942

Gelatin silver print

Image courtesy of George Eastman House, 1981:1029:0006, (C) Ansel Adams Trust

Unidentified photographer

Majesty and Beauty of Niagara

[Title on Object: The Falls, from Point View, American Side.] ca. 1865

Partial stereoview

Gelatin silver print

Original photograph courtesy of George Eastman House

Image courtesy of George Eastman House, 1981:8869:0008

Watkins, Carleton (American, 1829-1916)

Yosemite Falls

[Title on Object: Cho-Looke or Yosemite Fall From the Upper House]

1861

Gelatin silver print from an albumen silver print

Original photograph courtesy of George Eastman House

Image courtesy of George Eastman House, 1981:2899:0025 
10.

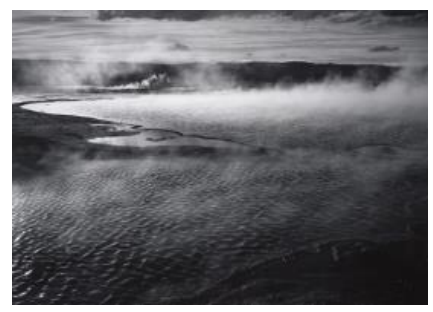

\section{Panel 4}

1.

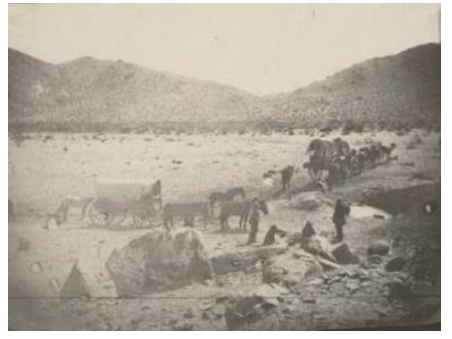

2. $\quad$ No image available
Adams, Ansel (American, 1902-1984)

Fountain Geyser Basin, Yellowstone National Park [Published title: Grand Prismatic Spring, Midway Geyser Basin, Yellowstone National Park, Wyoming] 1942

Gelatin silver print

Image courtesy of the Center for Creative Photography, (C) Ansel Adams Trust

D’Heureuse, Rudolph [unknown life dates.]

Rock Point

1863

Gelatin silver print from an albumen silver print Original photograph courtesy of Francis P. Farquhar

Image courtesy of Bancroft Library, University of California Berkeley, Online Archive of California

Russell, Andrew Joseph (American, 1830-1902)

Union Pacific Railroad, Citadel Rock, Green Valley River before 1870

Before 1870

Gelatin silver print from an albumen print Original photograph courtesy of Francis P. Farquhar 
3.

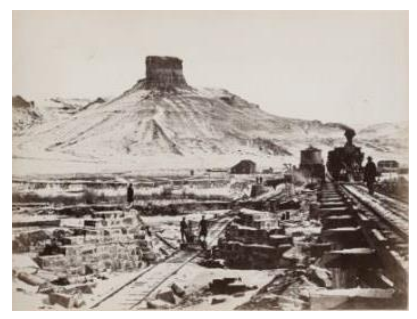

4.

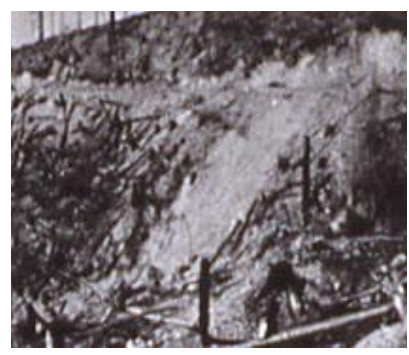

5.

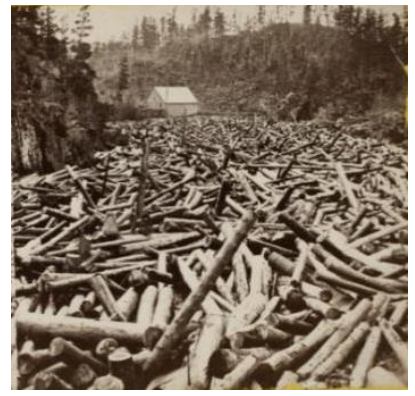

6. $\quad$ No image available
Unidentified Photographer

Hydraulic Gold Mining, near Dutch Flat, California before 1870

Before 1870

Gelatin silver print from an albumen silver print Original photograph courtesy of Francis P. Farquhar

Image courtesy of George Eastman House

Unidentified Photographer

Erosion caused by spur road construction, logging \& slash burning, Oregon

1950

Gelatin silver print

Original photograph courtesy of the U.S. Forest Service

Upton, Benjamin F. (American, 1818-after 1901)

Dells of St. Croix, Minnesota

n.d.

Partial stereoview

Gelatin silver print

Original photograph courtesy of George Eastman House

Image courtesy of George Eastman House, 1981:7078:0001

Unidentified Photographer

Effects of Overgrazing, Thin Cows, Arizona

1943

Gelatin silver print

Original photograph courtesy of the U.S. Forest Service 
7.

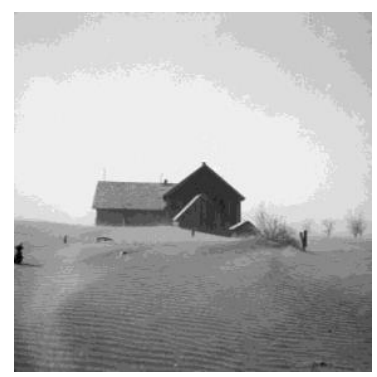

8.

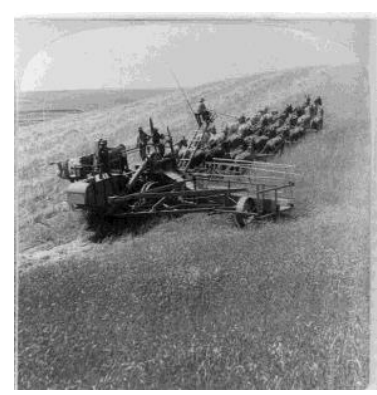

9.

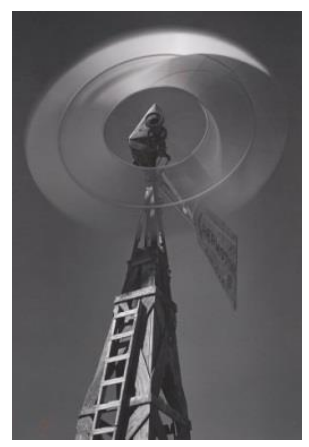

Rothstein, Arthur (American, 1915-1985)

Dust Storm Damage, Cimarron County, Oklahoma 1936

Gelatin silver print

Original photograph courtesy of the FSA

Image courtesy of the Library of Congress Online Collection

Unidentified Photographer, published by Underwood \& Underwood

Harvesting Great Western Wheat Fields, Washington [variant in series]

1902

Partial stereoview

Gelatin silver print

Original photograph courtesy of George Eastman House

Image courtesy of the Library of Congress

Adams, Ansel (American, 1902-1984)

Windmill, Owens Valley, California

[Published title: Aermotor Windmill Spinning, Owens Valley, near Independence, California]

ca. 1935

Gelatin silver print

Image courtesy of the Center for Creative Photography, (C) Ansel Adams Trust 
10.

No image available

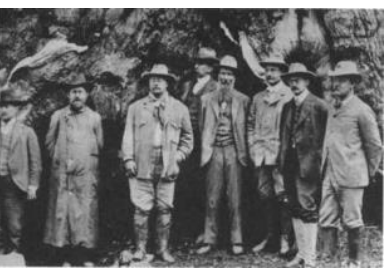

12.

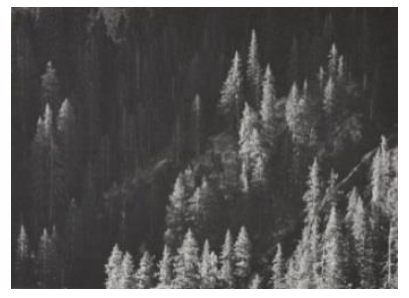

13.

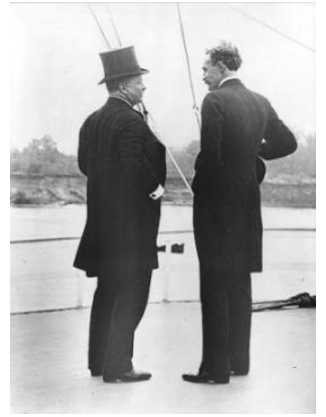

Hillers, John Karl (American, 1843-1925)

Major John Wesley Powell and Tau-gu, Chief of Paiutes 1873

Gelatin silver print

Original photograph courtesy of George Eastman House

Le Conte, Joseph N. (American, 1823-1901)

President Theodore Roosevelt, John Muir, Gifford Pinchot, party, in front of Grizzly Giant, Yosemite National Park 1903

Gelatin silver print

Adams, Ansel (American, 1902-1984)

National Forest, Mokelumne River area, California [variant] n.d.

Gelatin silver print

Image courtesy of the Center for Creative Photography, (C) Ansel Adams Trust

Unidentified Photographer

President Theodore Roosevelt and Gifford Pinchot 1907

Gelatin silver print

Original photograph courtesy of the U.S. Forest Service 
14. No image available

$15 . \quad$ No image available

16.

No image available

17.

No image available

$18 . \quad$ No image available
LeConte, Joseph N. (American, 1823-1901)

Hetch-Hetchy Valley

1903

Gelatin silver print

Original photograph courtesy of the Sierra Club

Colby, William (American, 1875-1964)

John Muir

n.d.

Gelatin silver print

Original photograph courtesy of the Sierra Club

Unidentified photographer

Stephen Mather inspecting trails, Glacier National Park n.d.

Original photograph courtesy of Alfred A. Knopf

Postlethwaite, Herman [unknown life dates.]

Dr. Hugh H. Bennett in his Virginia Garden 1951

Gelatin silver print

Original photograph courtesy of the U.S. Forest Service

Bourke-White, Margaret (American, 1904-1971)

Cornfield in the Dust Bowl

1934

Gelatin silver print

Original photograph courtesy of Life Magazine 


\section{Panel 5}

1.

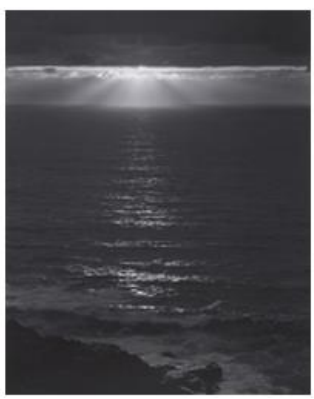

2.

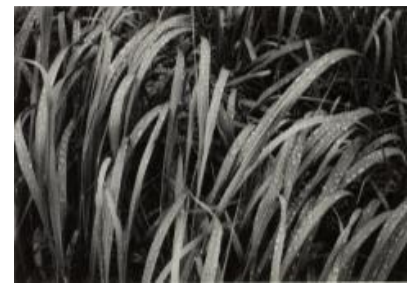

3.

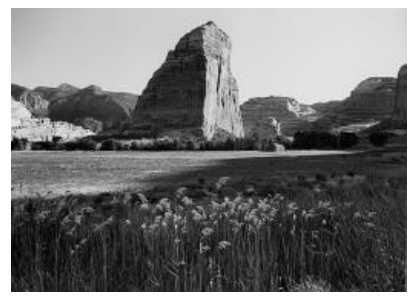

Adams, Ansel (American, 1902-1984)

Sundown, the Pacific

[Published title: Sundown, the Pacific, Carmel Highland, California]

1946

Gelatin silver print

Original photograph courtesy of American Trust Co.

Image courtesy of the Center for Creative Photography, (c) Ansel Adams Trust

Adams, Ansel (American, 1902-1984)

Grass in Rain, Alaska

[Published title: Grass in Rain, Glacier Bay National Park, Alaska]

1948

Gelatin silver print

Image courtesy of George Eastman House, 1972:0065:0051, (C) Ansel Adams Trust

Hyde, Philip (American, 1921-2006)

Steamboat Rock, Dinosaur National Monument n.d.

Gelatin silver print

Image courtesy of the Sierra Club Online Collection 
4. No image available

5. $\quad$ No image available

6.

No image available

7.

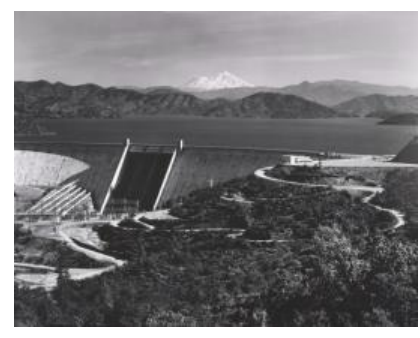

Unidentified Photographer

Mono Dam and Reservoir filled with silt 1938

Gelatin silver print

Original photograph courtesy of the U.S. Forest Service

Brower, David (American, 1912-2000)

Hetch-Hetchy Reservoir

n.d.

Gelatin silver print

Bradley, Harold (American, 1911-1969)

Lake Mead, after Drawdown

1954

Gelatin silver print

Adams, Ansel (American, 1902-1984)

Shasta Dam, California

n.d.

Gelatin silver print

Original photograph courtesy of the American Trust Co.

Image courtesy of the Center for Creative Photography, (C) Ansel Adams Trust 
8.

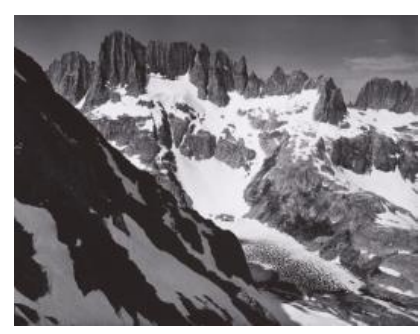

9.

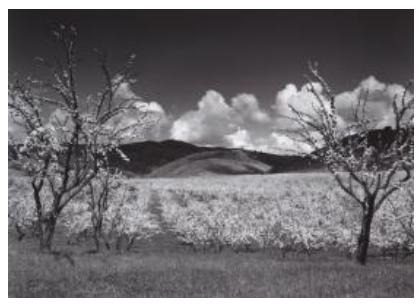

\section{Panel 6}

1.

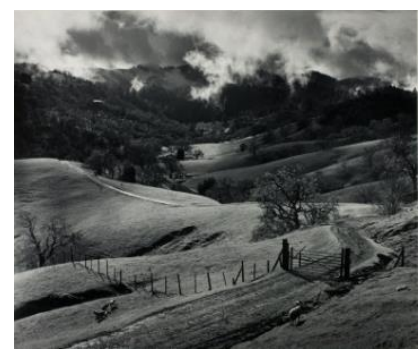

Adams, Ansel (American, 1902-1984)

The Minarets, Sierra Nevada

[Published title: The Minarets and Iceberg Lake from Volcanic Ridge, Sierra Nevada, California]

ca. 1935

Gelatin silver print

Image courtesy of the Center for Creative Photography, (c) Ansel Adams Trust

Adams, Ansel (American, 1902-1984)

Orchard in Bloom, Santa Clara Valley [California] ca. 1954

Gelatin silver print

Image courtesy of the Center for Creative Photography, (C) Ansel Adams Trust

Adams, Ansel (American, 1902-1984)

Pasture, Medocino County, California

[Published title: Pasture, Sonoma County, Northern California]

1951

Gelatin silver print

Original photograph courtesy of the American Trust Co.

Image courtesy of George Eastman House, 1972:0065:0038, (C) Ansel Adams Trust 
2.

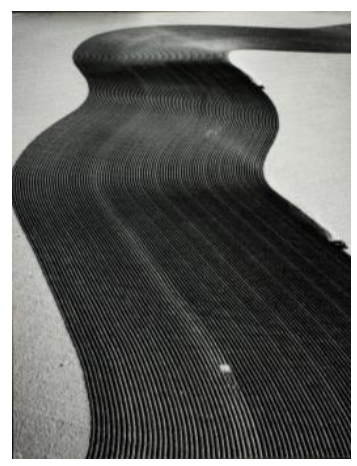

3. No image available

4.

No image available

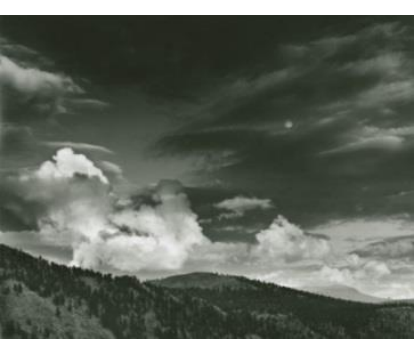

Bourke-White, Margaret (American, 1904-1971)

Contour Plowing, Colorado

1954

Gelatin silver print

Original photograph courtesy of Life Magazine

Image courtesy of George Eastman House, 1971:0155:0006

Washburn, Bradford (American, 1910-2007)

Mt. Hayes, Alaska

n.d.

Gelatin silver print

Unidentified Photographer

Putting the Bund, India

n.d.

Gelatin silver print

Original photograph courtesy of the Soil Conservation Service

Adams, Ansel (American, 1902-1984)

Moon and clouds over forest hilltops

[Published title: Moon and Clouds, Kern River Basin, Sierra Nevada, California]

ca. 1936

Gelatin silver print

Image courtesy of the Center for Creative Photography, (C) Ansel Adams Trust 
6.

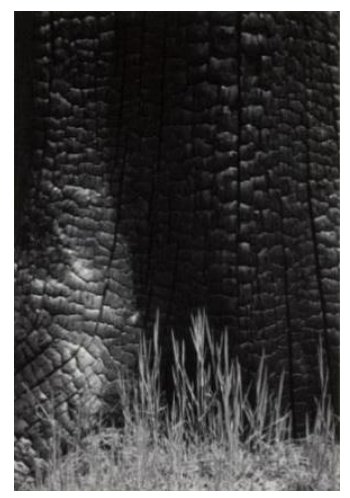

7.

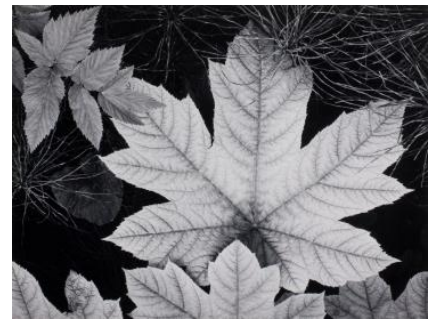

8.

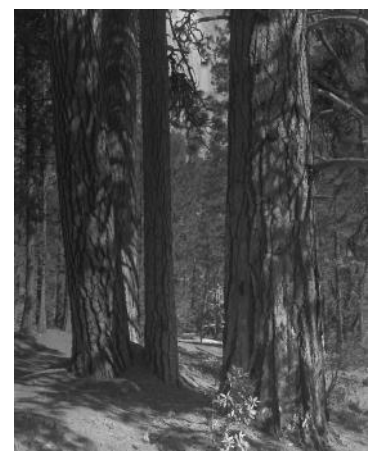

Adams, Ansel (American, 1902-1984)

Burnt Stump and Grass

[Published title: Burnt Stump and New Grass, Sierra Nevada, California]

1935

Gelatin silver print

Image courtesy of George Eastman House, 1967:0123:0029, (C) Ansel Adams Trust

Adams, Ansel (American, 1902-1984)

Thimbleberry Leaves and Horsetails, Alaska [Published title: Leaf, Glacier Bay National Park, Alaska] n.d.

Gelatin silver print

Image courtesy of George Eastman House, 1967:0123:0036, (C) Ansel Adams Trust

Adams, Ansel (American, 1902-1984)

Yellow Pines, Sierra Nevada

1950

Gelatin silver print

Image courtesy of the Center for Creative Photography, (C) Ansel Adams Trust 
9. No image available

\section{Panel 7}

1.

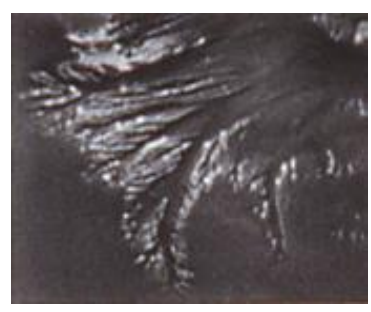

2.

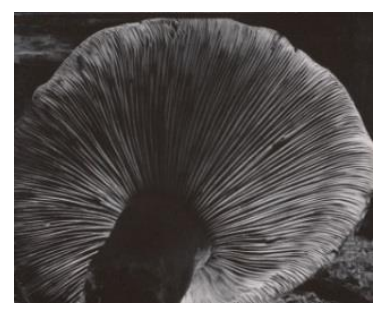

3.

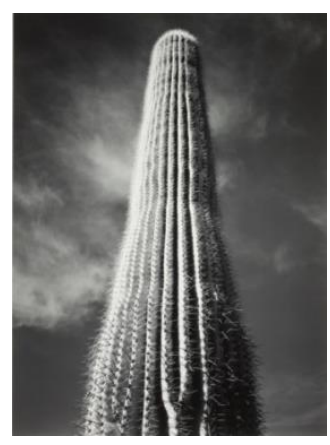

Adams, Ansel (American, 1902-1984)

Sitka Spruce, Alaska

n.d.

Gelatin silver print

Wright, Cedric (American, 1889-1959)

Beach Sand

n.d.

Gelatin silver print

Weston, Edward (American, 1886-1958)

Mushroom

[Published title: Toadstool]

1931

Gelatin silver print

Image courtesy of the Center for Creative Photography

Adams, Ansel (American, 1902-1984)

Saguaro, Organ Pipe National Monument [Published title: Saguaro Cactus, Arizona] 1942

Gelatin silver print

Image courtesy of George Eastman House, 1981:1016:0002, (C) Ansel Adams Trust 
4. No image available

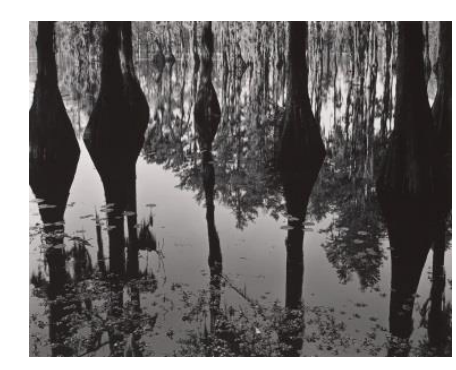

6.

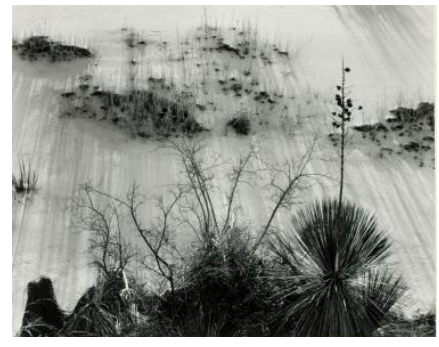

5.

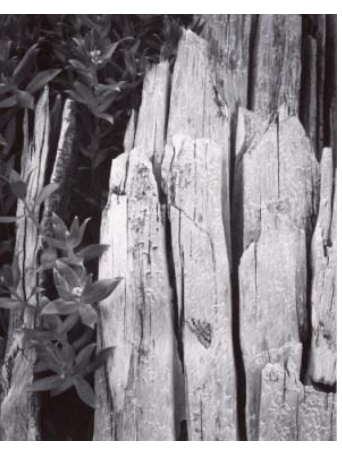

Weston, Edward (American, 1886-1958)

Cypress and Stone Crop, Point Lobos

1946

Gelatin silver print

Image courtesy of George Eastman House, 1976:0061:0054

Weston, Brett (American, 1911-1993)

Southern Swamp

[Published title: Cypress Swamp, North Carolina] 1947

Gelatin silver print

Image courtesy of the Center for Creative Photography

Weston, Brett (American, 1911-1993)

Yuccas, White Sands National Monument

[Published title: Yucca and Scrub, White Sands]

1946

From Portfolio White Sands

Gelatin silver print

Image courtesy of George Eastman House, 1979:0080:000

Adams, Ansel (American, 1902-1984)

Moth, Interglacial Forest, Glacier Bay National Monument, Alaska

1948

Gelatin silver print

Image courtesy of the Center for Creative Photography, (C) Ansel Adams Trust 
8.

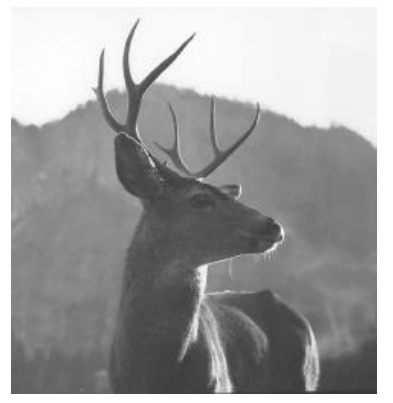

9.

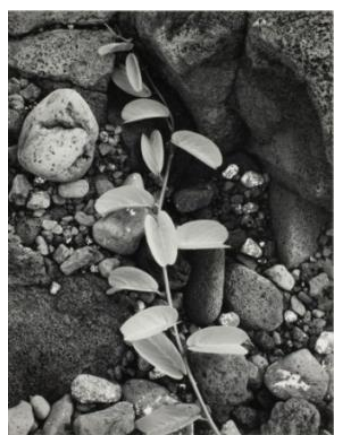

10.

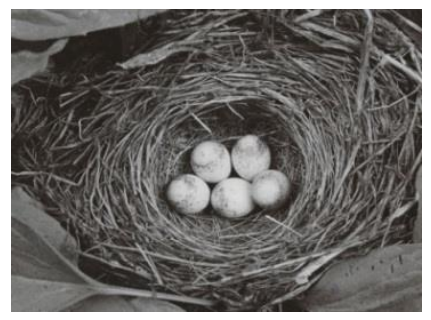

Adams, Ansel (American, 1902-1984)

Buck with Antlers [variant]

[Published title: Deer, Yosemite National Park, California] ca. 1935

Gelatin silver print

Adams, Ansel (American, 1902-1984)

Vine Among Volcanic Boulders, Hawaii

1948

Gelatin silver print

Image courtesy of George Eastman House, 1981:1016:0005, (C) Ansel Adams Trust

Adams, Ansel (American, 1902-1984)

Bird's Nest

[Published title: Eggs in Nest, Yosemite National Park] ca. 1936

Gelatin silver print

Image courtesy of the Center for Creative Photography, (C) Ansel Adams Trust 
11.

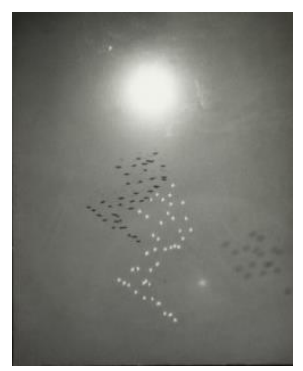

Adams, Ansel (American, 1902-1984)

Flight of Pelicans

[Published title: Snow Geese over Buena Vista Lake, California]

n.d.

Gelatin silver print

Image courtesy of George Eastman House, 1973:0063:0002

\section{Panel 8}

1.

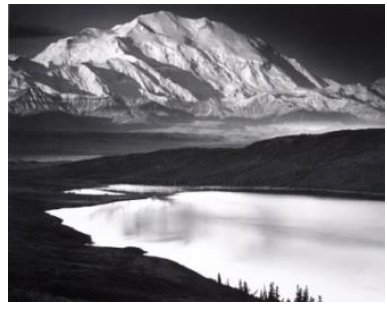

2.

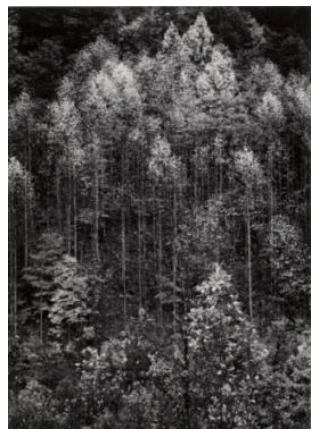

Adams, Ansel (American, 1902-1984)

Mount McKinley, Dawn, Mt. McKinley National Park, Alaska [Published title: Mount McKinley and Wonder Lake, Denali National Park, Alaska]

1947

Gelatin silver print

Image courtesy of the Center for Creative Photography, (C) Ansel Adams Trust

Adams, Ansel (American, 1902-1984)

Autumn Forest, Great Smoky National Park [Published title: Dawn, Autumn, Great Smoky Mountains National Park, Tennessee]

1948

Gelatin silver print

Image courtesy of George Eastman House, 1981:1017:0015, (C) Ansel Adams Trust 
3.

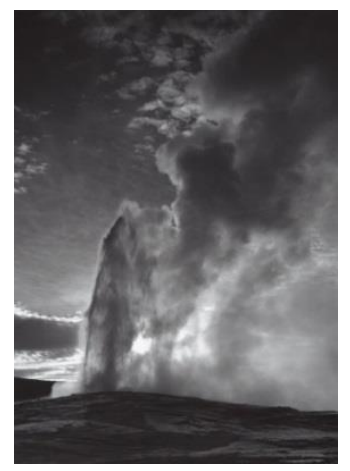

4.

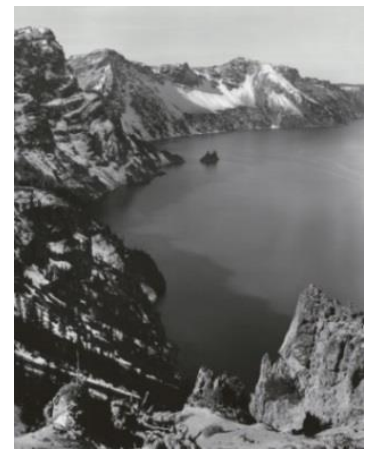

5.

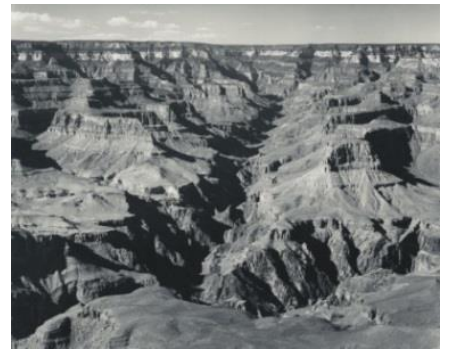

Adams, Ansel (American, 1902-1984)

Old Faithful Geyser, Yellowstone National Park [Wyoming]

1941-42

Gelatin silver print

Image courtesy of the Center for Creative Photography, (C) Ansel Adams Trust

Adams, Ansel (American, 1902-1984)

Crater Lake National Park

[Published title: Crater Lake and Snow, Crater Lake National Park, Oregon]

1943

Gelatin silver print

Image courtesy of the Center for Creative Photography, (C) Ansel Adams Trust

Adams, Ansel (American, 1902-1984)

Grand Canyon

[Published title: Grand Canyon from Yavapai Point, Bright Angel Canyon, Grand Canyon National Park, Arizona] 1942

Gelatin silver print

Image courtesy of the Center for Creative Photography, (C) Ansel Adams Trust 
6.

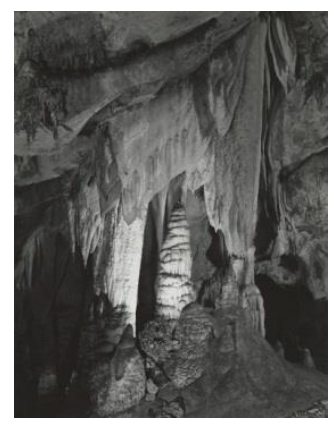

7.

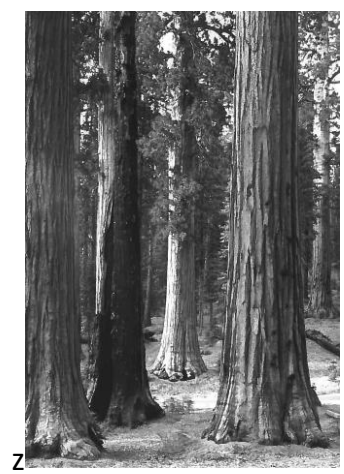

\section{Panel 9}

1.

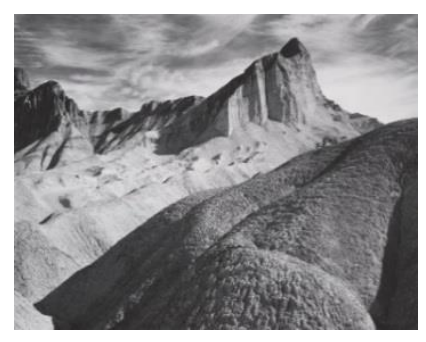

Adams, Ansel (American, 1902-1984)

Papoose Room, Carlsbad Caverns

n.d.

Gelatin silver print

Image courtesy of the Center for Creative Photography, (C) Ansel Adams Trust

Adams, Ansel (American, 1902-1984)

Sequoia Gigantea, Mariposa Grove, Yosemite National Park, California

n.d.

Gelatin silver print

Image courtesy of the Center for Creative Photography, (C) Ansel Adams Trust
Adams, Ansel (American, 1902-1984)

Manly Beacon, Death Valley National Monument ca. 1948

Gelatin silver print

Image courtesy of the Center for Creative Photography, (C) Ansel Adams Trust 
2.

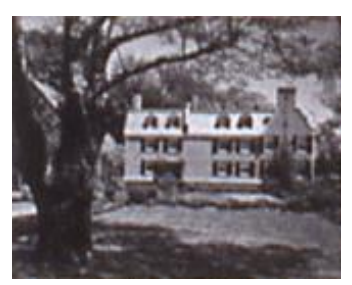

3. $\quad$ No image available

4.

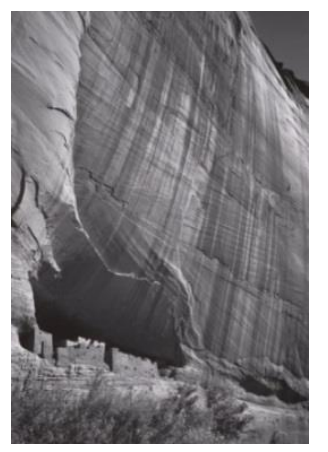

5.

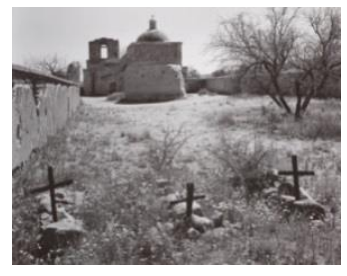

Chamberlain, Samuel (American, 1895-1975)

House From Lawn, Adams's National Historic Site, Quincy Massachusetts,

n.d.

Gelatin silver print

Anderson, Ralph H. (American, 1900-1964)

Abigail Adams's Collection

n.d.

Gelatin silver print

Original photograph courtesy of the National Park Service

White House Ruin, Canyon de Chelly National Monument, Arizona

1942

Gelatin silver print

Image courtesy of the Center for Creative Photography, (C) Ansel Adams Trust

Adams, Ansel (American, 1902-1984)

Mission from Graveyard, Tumacacori National Monument [Published title: Churchyard, Tumacacori Mission, Arizona] 1952

Gelatin silver print

Image courtesy of the Center for Creative Photography, (C) Ansel Adams Trust 
6. No image available

7.

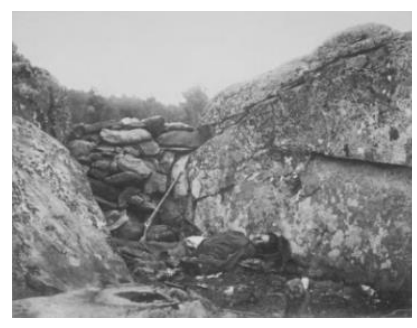

8.

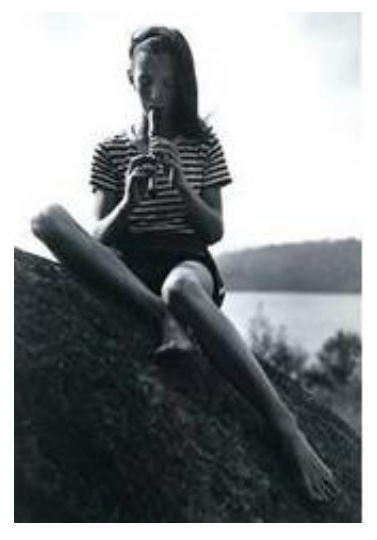

Unidentified Photographer

Abraham Lincoln, four days before his assassination 1865

Gelatin silver print from an albumen silver print or a collodion positive process

Original photograph courtesy of the U.S. National Archives

Gardner, Alexander (American, b. Scotland, 1821-1882)

Home of a Rebel Sharpshooter, Gettysburg

1863

Gelatin silver print from an albumen silver print

Original photograph courtesy of George Eastman House

Image courtesy of George Eastman House, 1981:0004:0041

Morgan, Barbara (American,1900-1992)

Girl with Recorder

[Published title: Girl Playing Recorder, Camp Treetops] 1945

Gelatin silver print 
9.

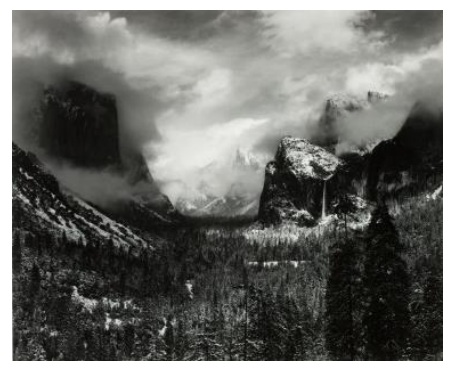

10.

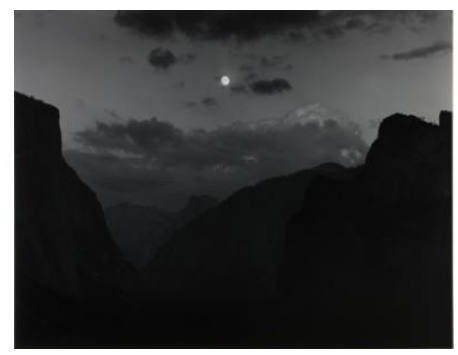

Adams, Ansel (American, 1902-1984)

Yosemite Valley, Winter Storm

[Published title: Clearing Winter Storm, Yosemite National Park, California]

ca. 1937

Gelatin silver print

Image courtesy of George Eastman House, 1981:1018:0009, (C) Ansel Adams Trust

Adams, Ansel (American, 1902-1984)

Yosemite Valley, Moonrise [California]

1944

Gelatin silver print

Image courtesy of George Eastman House, 1972:0065:0061, (C) Ansel Adams Trust

\section{Panel 10}

No photographs.

"Redman's Sierra" painted panel by Frann Spencer Reynolds with text by Richard Reynolds

\section{Panel 11}

No photographs.

"Whiteman's Sierra" painted panel by Frann Sepncer Reynolds with text by Richard Reynolds 


\section{Panel 12}

1.

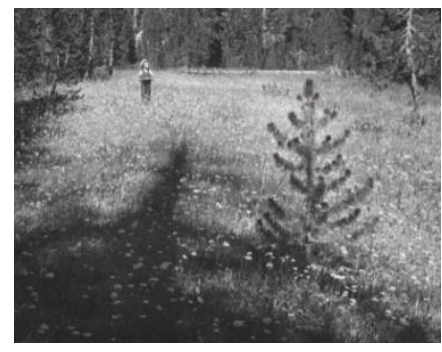

2.

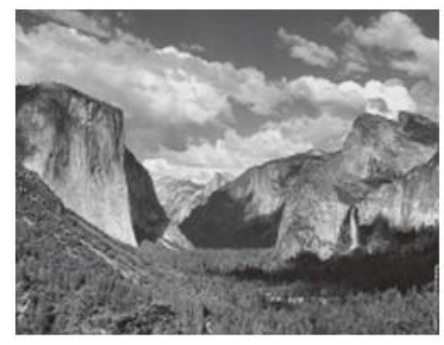

3.

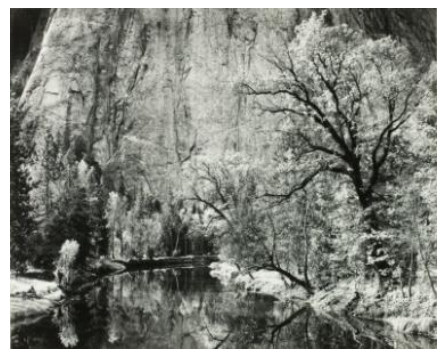

Adams, Ansel (American, 1902-1984)

Anne in Meadow

[Published title: Child in Mountain Meadow, Yosemite National Park, California]

ca. 1941

Gelatin silver print

Image courtesy of the Center for Creative Photography, (C) Ansel Adams Trust

Adams, Ansel (American, 1902-1984)

Yosemite Valley, Summer

ca. 1935

Gelatin silver print

Image courtesy of George Eastman House, 1972:0065:0070, (C) Ansel Adams Trust

Adams, Ansel (American, 1902-1984)

Cliffs and River, Autumn, Yosemite National Park [Published title: Merced River, Cliffs of Cathedral Rocks, Autumn, Yosemite National Park, California] 1939

Gelatin silver print

Image courtesy of George Eastman House, 1981:1018:0002, (C) Ansel Adams Trust 


\section{Panel 13}

1.

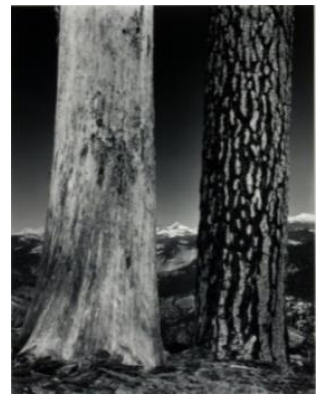

2.

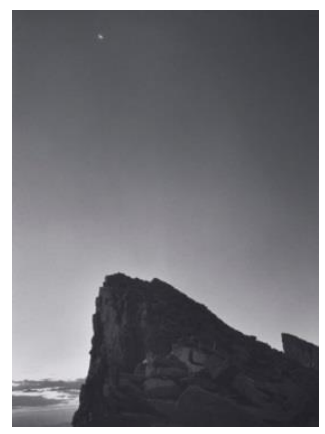

3.

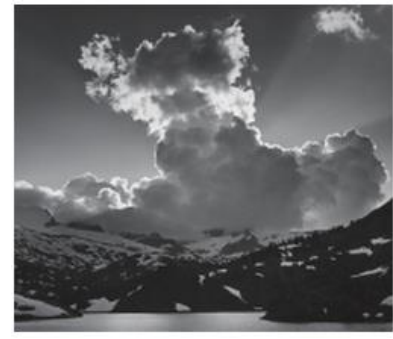

Adams, Ansel (American, 1902-1984)

Trees, Illilouette Ridge, Yosemite National Park [California]

1945

Gelatin silver print

Image courtesy of George Eastman House, 1972:0065:0062, (C) Ansel Adams Trust

Adams, Ansel (American, 1902-1984)

Mount Whitney, Dawn, Sequoia National Park [Sierra Nevada, California]

1932

Gelatin silver print

Image courtesy of the Center for Creative Photography, (C) Ansel Adams Trust

Adams, Ansel (American, 1902-1984)

Clouds, Sierra Nevada

[Published title: Thundercloud, Ellery Lake, High Sierra, California]

1934

Gelatin silver print

Image courtesy of the Center for Creative Photography, (C) Ansel Adams Trust 
4.

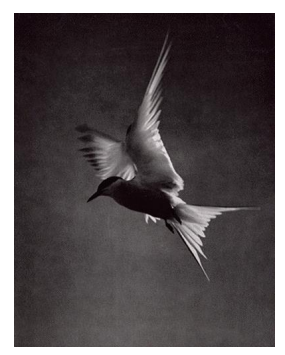

5.

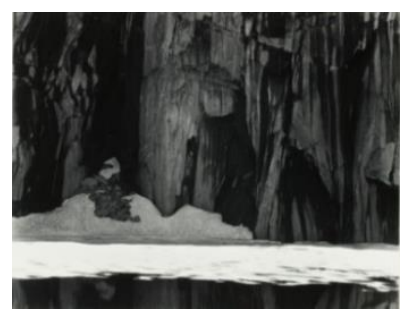

6.

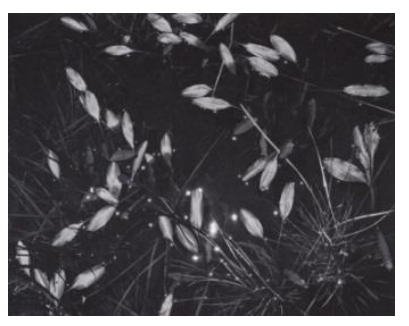

7.

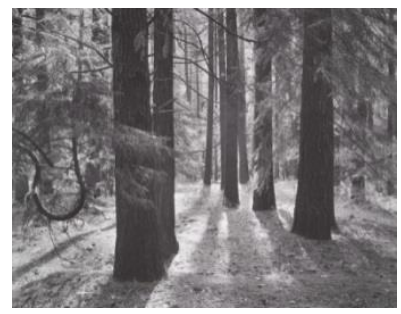

Porter, Eliot (American, 1901-1990)

Bird in Flight

n.d.

Gelatin silver print

Adams, Ansel (American, 1902-1984)

Frozen Lake and Cliffs, Sierra Nevada

[Published title: Frozen Lake and Cliffs, Kaweah Gap, Sierra Nevada, California]

1932

Gelatin silver print

Image courtesy of George Eastman House, 1972:0065:0074, (C) Ansel Adams Trust

Adams, Ansel (American, 1902-1984)

Pool, Leaves and Sun Reflections, Sierra Nevada [Published tile: Leaves on Pool, Sierra Nevada] ca. 1943

Gelatin silver print

Image courtesy of the Center for Creative Photography, (C) Ansel Adams Trust

Adams, Ansel (American, 1902-1984)

Cedars, Sierra Nevada

[Published title: Forest Floor, Yosemite National Park, California]

ca. 1950

Gelatin silver print

Image courtesy of the Center for Creative Photography, (C) Ansel Adams Trust 
8.

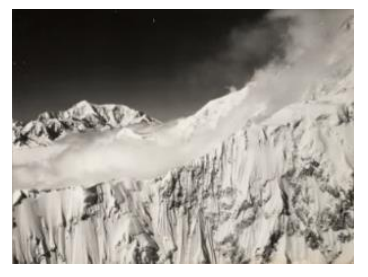

Panel 14

1.

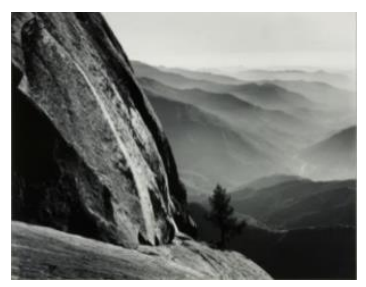

2.

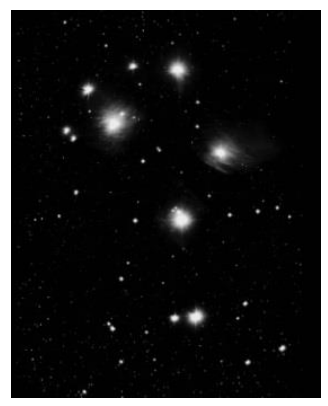

Washburn, Bradford (American, 1910-2007)

Mt. Saint Elias, Alaska

n.d.

Gelatin silver print

Image courtesy of George Eastman House, 1979:0208:0010

Adams, Ansel (American, 1902-1984)

From Moro Rock, Sequoia National Park [California] 1945

Gelatin silver print

Image courtesy of George Eastman House, 1972:0065:0064, (C) Ansel Adams Trust

Unidentified Photographer

Pleiades

n.d.

Gelatin silver print

Original photography courtesy of the Lick Observatory 
3.

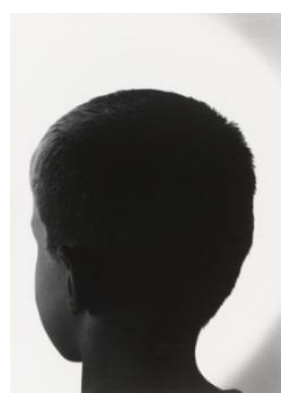

4.

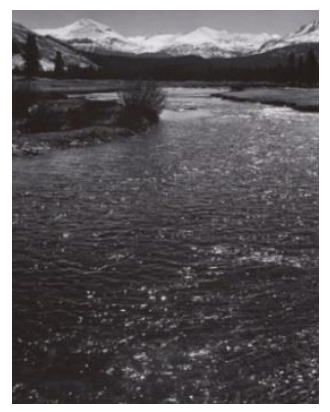

5.

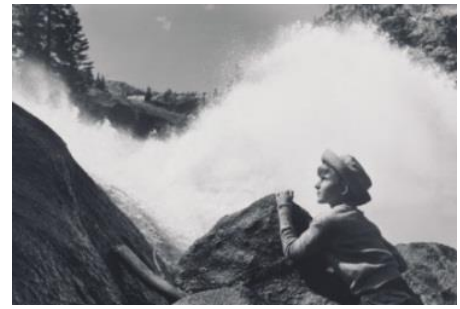

Morgan, Barbara (American, 1900-1992)

Head of Lloyd

1944

Gelatin silver print

Image courtesy of MoMA Online Collection

Adams, Ansel (American, 1902-1984)

Tuolumne River, Spring, Yosemite National Park

[Published title: Mount Dana and Mount Gibbs, Tuolumne River, Yosemite National Park, California] 1944

Gelatin silver print

Image courtesy of the Center for Creative Photography, (C) Ansel Adams Trust

Adams, Ansel (American, 1902-1984)

Boy and Waterfall, Yosemite National Park [Published title: Michael in the Sierra] 1943

Gelatin silver print

Image courtesy of the Center for Creative Photography, (c) Ansel Adams Trust 
6.

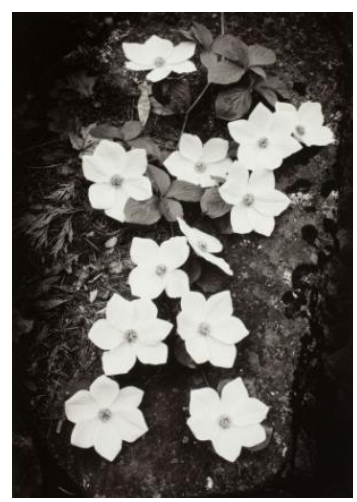

7.

No image available
Adams, Ansel (American, 1902-1984)

Dogwood Blossoms, Yosemite National Park ca. 1938

Gelatin silver print

Image courtesy of George Eastman House, 1981:1018:0010, (C) Ansel Adams Trust

Adams, Ansel (American, 1902-1984)

Heaven's Peak, Glacier National Park [Montana] 1942

Gelatin silver print 


\section{PERMISSIONS}

(C) Nancy Newhall, (c) 2014, the Estate of Beaumont and Nancy Newhall. Permission to reproduce courtesy of Scheinbaum and Russek Ltd., Sante Fe, New Mexico.

(C) Ansel Adams, (C) 2014, The Ansel Adams Publishing Rights Trust.

The author has obtained permission from the Colby Memorial Library, Sierra Club, for use of its historical archive. 


\section{SCIEINBAUM \\ RUSSEK ITD}

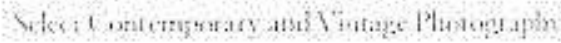

July 30,2014

\section{A UTHORIZATION \& PERMISSION}

Permission to reproduce is granted to:

Josephine Minhinnett

38 William Carson Cres. \#103

Toronto, Ontario

M2P $2 \mathrm{H} 2$, Canada

$512-993-9718$

joscphine,minhinnett@ryersom,ca

Text to be reproduced;

\begin{tabular}{|c|c|}
\hline Author & Naney Newhall \\
\hline Tifle & Various correspondence from Nancy Newhall to Ansel Adams \\
\hline $\begin{array}{l}\text { Credit } \\
\text { Line }\end{array}$ & $\begin{array}{l}\text { Text date, Nancy Newhall, } 82014 \text {, the Estate of Beaumont and Nancy Newhall. Permission } \\
\text { to reproduce courtesy of Seheinbatm and Russek L.td., Santa Fe, New Mexico }\end{array}$ \\
\hline Source & Center for Creative Photograplyy \\
\hline
\end{tabular}

Permission is granted for ane-time use only for the publication further described below. All rights reserved.

Project Title: [Working title]: This Is the American Earth: An Exhibition and Book by Ansel Adams, Nancy Newhall, and the Sierra Club

Publisher:

N/A

Projected date of September 2014

publication:

Publication Details: Thesis presented to Ryerson Lniversity, Toronto and the George Listman House,

Rochester NY in partial fulfillment of the requirements of a Master of Ans in the program of Photograjhic

Preservation and Collections Management.

Pernissions to repraduce the text is granted wijh the strict mnderstanding that flic text will not be altered in any

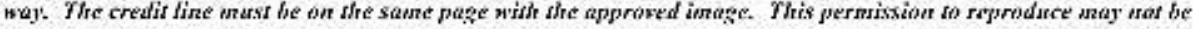
transferred, in wholc or in part, to any third party. (SEE CONDITIONS FOR REPRODUCTSON).

Agrecd and Accepted:

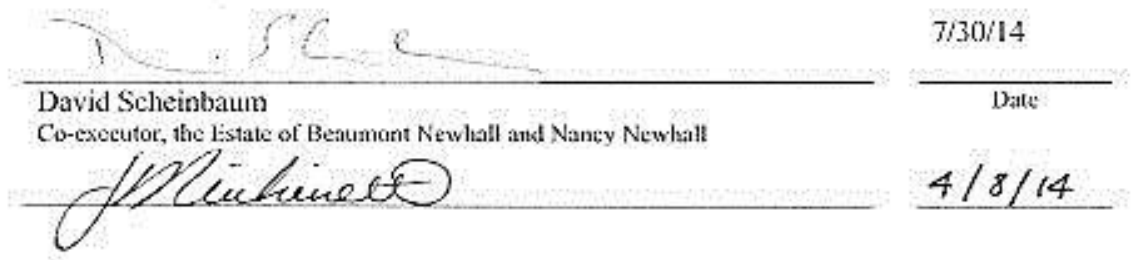


Google Apps at

Ryerson University

Josephine Minhinnett <josephine.minhinnett@ryerson.ca>

\section{re: Fwd: American Earth Exhb Checklist}

Claudia Rice <claudia@adamstrust.com>

Fri, Aug 8, 2014 at 4:02 PM

To: Josephine Minhinnett <josephine.minhinnett@ryerson.ca>

Hi Josephine,

No worries. You have permission to proceed as set forth in your August 7 email. Please include our copyright statement in the appropriate section of your thesis:

Text by Ansel Adams.

(c) 2014 The Ansel Adams Publishing Rights Trust

Best wishes,

Claudia Rice

Business Manager

The Ansel Adams Publishing Rights Trust

claudia@adamstrust.com

[Quoted text hidden]

[Quoted text hidden]

$<$ Minhinnett_This Is the American Earth_Adams Permissions.docx > 


\section{COLBY MEMORIAL LIBRARY, SIERRA CLUB}

\section{ARCHIVE USE AGREEMENT}

THIS AGREEMENT is made and entered into as of the $\underline{22}$ day of August, 2014, by and between Sierra Club and Josephine Minhinnett ("User").

WHEREAS Sierra Club maintains an historical archive of photographs, films, and other materials at the Colby Memorial Library (the "Works"); and

WHEREAS User desires to use one or more of the Works, [that is, one image by Cedric Wright, Stump in Thunderstorm]

NOW, THEREFORE, in consideration of the premises and the mutual promises hereinafter set forth, Sierra Club and User hereby agree as follows:

1. Permission. Sierra Club hereby grants to User, on a non-exclusive basis, permission to use those rights in the Works as Sierra Club may possess for one-time use in the [appendix to her master's thesis] entitled [Exhibition Checklist for This Is the American Earth]. User acknowledges that, other than the right to possess a physical copy of the Works in its archives, Sierra Club may not own or have a license to use any other rights in the Works, including, but not limited to, copyright, trademark, or publicity rights. Sierra Club does not grant to User permission to resell, misuse, or alter the Works. If Sierra Club determines that User has resold, misused, or altered the Works, it may terminate the permission granted herein immediately.

2. No Warranties and Release. User agrees and acknowledges that Sierra Club is making no warranties in regards to the Works, including, but not limited to, any warranties of title, fitness for any purpose, or as to what rights it may have in the Works. User hereby forever releases Sierra Club from, and shall not seek indemnification for, any third-party claims, damages, or liabilities, including attorneys' fees, arising from or related to the Works or User's possession, display, use, or exploitation of the Works, including, but not limited to, claims asserting trademark, copyright, patent, trade secret, privacy, or publicity rights, or claims for defamation, libel, or slander. Furthermore, User shall indemnify Sierra Club from any third-party claims, damages, or liabilities, including attorneys' fees, arising from or related to User's possession, display, use, or exploitation of the Works, including without limitation claims asserting trademark, copyright, patent, trade secret, privacy, or publicity rights, or claims for defamation, libel, or slander. This Section 2 shall survive the termination of this Agreement.

3. Credit and Compensation. User shall include the following credit, or another form of credit agreed upon by Sierra Club and User, in connection with each public use User makes of a Work: "[User] thanks the Colby Memorial Library, Sierra Club for use of its historical archives."

4. $\quad$ Assignment. This Agreement may not be assigned by either party without the written permission of the other party.

5. Miscellaneous. This Agreement shall be construed and interpreted according to the laws of the State of California. The parties consent to jurisdiction and venue in courts located in the State of California for the resolution of any action arising out of or relating to this Agreement. This Agreement cancels and supersedes all prior negotiations and understandings between the parties relating to rights in the Works, and contains all of the terms, covenants, conditions, representations, and warranties of the parties relating to rights in the Works. The Agreement may not be modified except by a written instrument signed by both parties. No waiver by either party of any failure by the other to keep or perform any covenant or condition of this Agreement shall be deemed a waiver of any preceding or succeeding breach of the same or any other covenant or condition. 


\section{BIBLIOGRAPHY}

\section{PRIMARY SOURCES}

Bancroft Library, University of California, Berkeley

Sierra Club Member Papers

Sierra Club Office of the Executive Director Records

Center for Creative Photography, University of Arizona, Tucson

Ansel Adams Archive

Nancy Newhall Collection

Colby Memorial Library, Sierra Club

Collection of David Featherstone

Getty Research Institute, Los Angeles

Nancy Newhall Papers

National Archives and Records Association

Book Development Files 1944-1968, Records of the USIA, Record Group 306

Online Archive of California. http://www.oac.cdlib.org/.

Sierra Club Board of Directors Meeting Minutes, 1954 and 1955

Papers of John F. Kennedy, Presidential Papers. http://www.jfklibrary.org/.

President's Office Files, Series 7

Smithsonian Institution Archives

Collection 290, Box 58, Folder 11

\section{BOOKS AND ARTICLES}

Adams, Ansel. Ansel Adams: An Autobiography. Edited by Mary Street Alinder. New York: Little Brown and Co., 1985.

_ Basic Photo. Vol. 1 The Camera and Lens. Vol. 2 The Negative. Vol. 3 The Print. New York: Morgan and Lester, 1948-1950.

" "Conversations with Ansel Adams." Oral history. Conducted by Ruth Teiser and Catherine Harroun, 1972, 1974, 1975. Sierra Club Oral History Series. Regional Oral History Office, Bancroft Library, University of California, Berkeley, 1978. http://bancroft.berkeley.edu/ ROHO/collections/subjectarea/natres/sierraclub.html.

_. Illustrated Guide to Yosemite Valley. Edited by Virginia Adams. San Francisco: H.S. Crocker Co., 1940.

My Camera in the National Parks. Boston: Houghton Mifflin, 1950. 
My Camera in Yosemite Valley. Edited by Virginia Adams. San Francisco: H.S. Crocker Co., 1940.

. Portfolio Two: The National Parks and Monuments. San Francisco: Grabhorn Press, 1950.

. "The Profession of Photography." Aperture 1, no.3 (1952): 1-17.

. "Retrospect: Nineteen-Thirty-One." Sierra Club Bulletin 17, no. 1 (February 1932): 1-11.

- Sierra Nevada: The John Muir Trail. Berkeley: Archetype Press, 1938.

- Making a Photograph: An Introduction to Photography. New York: The Studio Publications, 1935.

. Yosemite Valley. Edited by Nancy Newhall. San Francisco: 5 Associates, 1959.

Adams, Ansel, and Mary Austin. Taos Pueblo. San Francisco: Grabhorn Press, 1930.

Alinder, Mary Street. Ansel Adams: A Biography. New York: Henry Holt and Co., 1996.

Alinder, Mary Street, and Andrea Gray Stillman, eds. Ansel Adams: Letters and Images 1916-1984.

Boston: Little, Brown and Company, 1988.

Backes, David. A Wilderness Within: The Life of Sigurd F. Olson. Minneapolis: University of Minnesota Press, 1997.

Brower, David R. “David R. Brower: Environmental Activist, Publicist, and Prophet." Oral history. Conducted by Susan Schrepfer, 1974-1978. Sierra Club Oral History Series. Regional Oral History Office, Bancroft Library, University of California, Berkeley, 1980. https://ia600308. us.archive.org/7/items/environmentalact00browrich/environmentalact00browrich.pdf.

—. "Beyond the Skiways." Sierra Club Bulletin 23 (April 1938): 40-45.

Work in Progress. Salt Lake City: Peregrine Smith, 1991.

Brustein, Robert. Review of Nothing Personal, by Richard Avedon. New York Review of Books, 17 December 1964.

Bunnell, Peter C., Maria B. Pellerano, and Joseph B. Rauch. Minor White: The Eye That Shapes. Princeton: The Art Museum, Princeton University, 1989. Published in conjunction with the exhibition of the same name, shown at the Museum of Modern Art in New York.

Cartier-Bresson, Henri. Les Européens, Photographies. Paris: Verve, 1955.

Cohen, Michael P. The History of the Sierra Club, 1892-1970. San Francisco: Sierra Club Books, 1988.

"The Controversial Family of Man." Review of The Family of Man exhibition, by Edward Steichen at the Museum of Modern Art, New York. Aperture 3, no. 2 (1955): 8-27. 
Curtis, Heber D. Photographs of Halley's Comet Made at Lick Observatory (June 1, 1910). Astronomical Society of the Pacific 22. https://archive.org/details/jstor-40691710.

Deschin, Jacob. "Panoramic Show at the Museum of Modern Art." Review of The Family of Man exhibition, by Edward Steichen. New York Times, 30 January 1955. Reprinted in Aperture 3, no. 2 (1955): 8-11.

De Voto, Bernard. “Shall We Let Them Ruin Our National Parks.” Harper's, 22 July 1950, 17.

Dunaway, Finis. Natural Visions: The Power of Images in American Environmental Reform. Chicago: The University of Chicago Press, 2005.

Edkins, Diana E. “Nancy Newhall, 1908-1974.” Afterimage 2, no. 3 (September 1974): 11.

Edwards, Hugh. Review of This Is the American Earth exhibition, by Ansel Adams and Nancy Newhall. Image 1 (March 1960): 48.

Farquhar, Francis Peloubet. History of the Sierra Nevada. 2nd ed. Berkeley: University of California Press, 2007.

Featherstone, David. "This Is the American Earth: A Collaboration by Ansel Adams and Nancy Newhall." In Untitled 55, Ansel Adams New Light: Essays on his Legacy and Legend, edited by Michael Read, 63-73. Carmel: Friends of Photography, 1993.

Frankenstein, Alfred. Review of This Is the American Earth exhibition, by Ansel Adams and Nancy Newhall. The San Francisco Chronicle, n.d. Reprinted in Aperture 3, no. 2 (1955): 8-27.

Gernsheim, Helmut. "Book Reviews: Photographic Images." Review of This Is the American Earth, by Ansel Adams and Nancy Newhall. Motif 8 (1961): 98.

Haip, Renée. "Forging the Wilderness Idea." In Untitled 55, Ansel Adams New Light: Essays on his Legacy and Legend, edited by Michael Read, 75-82. Carmel: Friends of Photography, 1993.

Hammond, Anne. Ansel Adams: Divine Performance. New Haven; London: Yale University Press, 2002.

Hannigan, Ed, ed. "New Books." Review of This Is the American Earth, by Ansel Adams and Nancy Newhall. U.S. Camera, September 1960, 26.

Harris, David. "The Americans at 50: A Review of the Exhibition and Related Publications of Looking In: Robert Frank's The Americans." Photography \& Culture 4, no. 1 (March 2011): 93-101. doi: http://dx.doi.org/10.2752/175145211X12899905861555.

Heyman, Therese Thau, ed. Seeing Straight: The f.64 Revolution in Photography. Oakland: Oakland Museum, 1992.

Hutchings, James Mason. In the Heart of the Sierras. Oakland: Pacific Press Publishing House, 1886. 
Klochko, Deborah, ed. Nancy Newhall: A Literacy of Images. San Diego: Museum of Photographic Arts, 2008. Published in conjunction with the exhibition of the same name, shown at the Museum of Photographic Arts.

Lange, Dorothea, and Paul S. Taylor. An American Exodus: A Record of Human Erosion. New York: Reynal and Hitchcock, 1939.

Lowenthal, David. George Perkins Marsh: Prophet in Conservation. Washington: University of Washington Press, 2009.

MacKaye, Benton. Review of This Is the American Earth, by Ansel Adams and Nancy Newhall. National Parks Magazine, February 1960.

Manchester, Ellen. "Ansel Adams: About His Work, Not His Editor." Review of Ansel Adams, edited by Liliane de Cock. Afterimage 1, no. 7 (May 1973): 5.

Morgan, Barbara. Barbara Morgan. Introduction by Peter Bunnell. New York: Morgan \& Morgan Inc., 1972.

Morris, John G. Get the Picture: A Personal History of Photojournalism. Chicago: University of Chicago Press, 2002.

Morris, John G. "This Is the World At Home." Pt. 9. People Are People the World Over. Ladies Home Journal, January 1949, 44-45.

Museum of Modern Art. "Image of Freedom Photography Competition Opens." Press release, 20 June 1941. http://www.moma.org/momaorg/shared/pdfs/docs/press_archives /713/releases/MOMA_1941_0050_1941-06-20_41620-49.pdf?2010.

Natanson, Nick. “Old Frontiers, New Frontiers: Reassessing USIA and State Department Photography of the Cold War Era." Accessed May 27, 2014. http://www.archives.gov/ research/foreign-policy/cold-war/conference/natanson.html.

National Park Service. “Park Statistics.” Accessed 16 July 2014. http://www.nps.gov/yose/ naturescience/park-statistics.htm.

Newhall, Beaumont. “History of the 35mm Camera." Pts. 1 and 2. Modern Photography, June 1953, 77; July 1953, 76.

The History of Photography from 1938 to the Present. New York: The Museum of Modern Art, 1982.

."Fox Talbot, Esq." Pts. 1 and 2. Modern Photography, December 1952, 86; January 1953, 66. Reprinted in Image 8, no. 2 (June 1959): 60-75.

“More About Clichés Verres.” Modern Photography, September 1949, 144.

“Monsieur Daguerre." Pts. 1 and 2. Modern Photography, December 1951, 144; January $1952,76$. 
Photography 1839-1937. New York: The Museum of Modern Art, 1937.

Photography: A Short Critical History. New York: The Museum of Modern Art, 1938.

Newhall, Beaumont, and Nancy Newhall. Masters of Photography. New York: George Braziller, 1958.

Newhall, Beaumont, and Peter Hunt Thompson, eds. Untitled 10, Nancy Newhall. Carmel: The Friends of Photography, 1976.

Newhall, Nancy. Ansel Adams: Volume I, The Eloquent Light. 2nd ed. Millerton: Aperture, 1980.

“The Caption: The Mutual Relation of Words/Photographs," Aperture 1, no. 1 (1952): 1729.

—. "Controversy and the Creative Concepts." Aperture 2, no. 2 (July 1953): 3-13.

- From Adams to Stieglitz: Pioneers of Modern Photography. Foreword by Michael E. Hoffman. Introduction by Beaumont Newhall. New York: Aperture Foundation, 1989.

“Television and the Arts." Parnassus 40, no. 4 (1940): 37-8. doi: 10.2307/772164.

—. Review of Born Free and Equal, by Ansel Adams. Photo Notes, June 1946, 3-5.

Review of The Inhabitants, by Wright Morris. Photo League Bulletin, November 1946, 2.

Newhall, Nancy, and Ansel Adams. Death Valley. San Francisco: Five Associates, 1954.

Fiat Lux: The University of California. New York: McGraw Hill, 1967.

Mission San Xavier del Bac. San Francisco: Five Associates, 1954.

. The Pageant of History and the Panorama of Today in Northern California. San Francisco: American Trust Co., 1954.

This Is the American Earth. Revised edition. San Francisco: Sierra Club Books, 1992.

O’Toole, Erin Kathleen. “No Democracy in Quality: Ansel Adams, Beaumont and Nancy Newhall, and the Founding of the Department of Photographs at the Museum of Modern Art." PhD diss., University of Arizona, 2010. ProQuest (UMI 3402933).

Parr, Martin, and Gerry Badger. The Photobook: A History, Volume II. London: Phaidon Press, 2006.

Reed, Sarah Orleans. “The Publication of Paul Ehrlich's The Population Bomb by the Sierra Club, 1968: Wilderness-Thinking, Neo-Malthusianism, and Anti-Humanism." Undergraduate honors thesis, Wesleyan University, 2008. http://wesscholar.wesleyan.edu/cgi/view content.cgi? article=1064\&context=etd_hon_theses. 
Robertson, Thomas. "This Is the American Earth: American Empire, the Cold War, and American Environmentalism." Diplomatic History 32, no. 4 (September 2008): 561-84. doi: 10.1111/ j.1467-7709.2008.00713.x.

Rome, Adam. The Bulldozer in the Countryside Suburban Sprawl and the Rise of American Environmentalism. Cambridge: Cambridge University Press, 2001.

Sandeen, Eric J. Picturing An Exhibition: The Family of Man and 1950s America. Albuquerque: University of New Mexico Press, 1995.

Senf, Rebecca. "Ansel Adams's 'Practical Modernism' : The Development of a Commercial Photographer, 1916-1936.” PhD diss., Boston University, 2008. ProQuest (UMI 3298676).

“Serene Sermon in Sierra." Life, 28 November 1960, 10-11.

Sierra Club. "History: Ansel Adams." http://vault.sierraclub.org/history/ansel-adams/default.aspx.

Sierra Club. “History: Sierra Club Timeline.” http://www.sierraclub.org/history/timeline.aspx.

Sobieszek, Robert, and Patricia A. Slahucka. Beaumont Newhall. Rochester: George Eastman House, 1971.

Spaulding, Jonathan. Ansel Adams and the American Landscape: A Biography. Berkeley: University of California Press, 1995.

Stegner, Wallace. This Is Dinosaur: Echo Park Country and Its Magic Rivers. New York: Knopf, 1955.

Steichen, Edward. The Family of Man. New York: Museum of Modern Art, 1955. Published in conjunction with the exhibition of the same name.

Stillman, Andrea Gray, ed. Ansel Adams: 400 Photographs. New York; London; Boston: Little, Brown and Company, 2006.

Strand, Paul and Nancy Newhall. Time in New England. New York: Oxford University Press, 1950.

Strand, Paul. Review of An American Exodus, by Dorothea Lange and Paul S. Taylor. Photo Notes, March-April 1940.

Szarkowski, John. "Kaweah Gap and Its Variants." In Untitled 37, Ansel Adams: 1902-1984, edited by James Alinder, 13-15. Carmel: The Friends of Photography, 1984.

Teale, Edwin Way. The Wilderness World of John Muir. Boston: Houghton Mifflin, 1954.

"This Is the American Earth." Review of This Is the American Earth exhibition, by Ansel Adams and Nancy Newhall. Aperture 3, no. 2 (1955): 28-34.

Walrath, Jean. "Grandeur of the Earth." Review of This Is the American Earth, by Ansel Adams and Nancy Newhall. Rochester Democrat and Chronicle, February 14, 1960. 
Wehr, Kevin. America's Fight Over Water: The Environmental and Political Effects of Large Scale Water Systems. London: Routledge, 2004.

Weston, Edward. The Daybooks of Edward Weston, Volume 1: Mexico. Edited by Nancy Newhall. New York: George Eastman House, 1961.

Weston, Edward. The Daybooks of Edward Weston, Volume 2: California. Edited by Nancy Newhall. New York: George Eastman House, 1966.

Wilson, MaLin. "Walking on the Desert in the Sky: Nancy Newhall's Words and Images." In The Desert is No Lady: Southwestern Landscapes in Women's Writing and Art, edited by Vera Norwood and Janice Monk, 47-61. Tucson: University of Arizona Press, 1997.

Wilson-Powell, MaLin. “An Eloquent Image.” In Nancy Newhall: A Literacy of Images, edited by Deborah Klochko, 20-41. San Diego: Museum of Photographic Arts, 2008. Exhibition catalogue.

Wright, Morris. The Inhabitants. New York: C. Scribner's Sons, 1946.

Sierra Club Exhibit Format Series (in order of publication date)

Adams, Ansel, and Nancy Newhall. This Is the American Earth. Exhibit Format Series 1. San Francisco: Sierra Club Books, 1960.

Wright, Cedric. Words of the Earth. Exhibit Format Series 2. Edited by Nancy Newhall. San Francisco: Sierra Club Books, 1960.

Adams, Ansel. These We Inherit: The Parklands of America. Exhibit Format Series 3. San Francisco: Sierra Club Books, 1962.

Porter, Eliot. In Wildness is the Preservation of the World. Exhibit Format Series 4. San Francisco: Sierra Club Books, 1962.

- The Place No One Knew: Glen Canyon on the Colorado. Exhibit Format Series 5. San Francisco: Sierra Club Books, 1963.

Hyde, Philip, and François Leydet. The Last Redwoods: Photographs and Story of a Vanishing Scenic Resource. Exhibit Format Series 6. San Francisco: Sierra Club Books, 1963.

Newhall, Nancy. Ansel Adams: Volume I, The Eloquent Light. Exhibit Format Series 7. San Francisco: Sierra Club, 1964.

Leydet, François. Time and the River Flowing: Grand Canyon. Exhibit Format Series 8. San Francisco: Sierra Club Books, 1964.

Kauffman, Richard. Gentle Wilderness: The Sierra Nevada. Exhibit Format Series 9. San Francisco: Sierra Club Books, 1964.

Adams, Ansel. Not Man Apart. Exhibit Format Series 10. San Francisco: Sierra Club Books, 1965. 
Manning, Harvey. The Wild Cascades: Forgotten Parkland. Exhibit Format Series 11. San Francisco: Sierra Club Books, 1965.

Hornbein, Thomas F. Everest: The West Ridge. Exhibit Format Series 12. San Francisco: Sierra Club Books, 1965.

Porter, Eliot. Summer Island: Penobscot Country. Exhibit Format Series 13. San Francisco: Sierra Club Books, 1966.

Hyde, Philip, and Stephen C. Jett. Navajo Wildlands: As Long as the Rivers Shall Run. Exhibit Format Series 14. San Francisco: Sierra Club Books, 1967.

Wenkam, Robert. Kauai and the Park Country of Hawaii. Exhibit Format Series 15. Edited by Kenneth Brower. San Francisco: Sierra Club Books, 1967.

Bohn, Dave. Glacier Bay: The Land and the Silence. Exhibit Format Series 16. San Francisco: Sierra Club Books, 1967.

Porter, Eliot, and Joseph Wood Krutch. Baja California and the Geography of Hope. Exhibit Format Series 17. San Francisco: Sierra Club Books, 1967.

Johnston, Nancy, Retta Johnston, and Mireille Johnston. Central Park Country; A Tune Within Us. Exhibit Format Series 18. San Francisco: Sierra Club Books, 1968.

Porter, Eliot Galapagos: The Flow of Wildness, Volume 1: Discovery. Exhibit Format Series 19. San Francisco: Sierra Club Books, 1968.

Galapagos: The Flow of Wildness, Volume 2: Prospect. Exhibit Format Series 20. San Francisco: Sierra Club Books, 1968. 